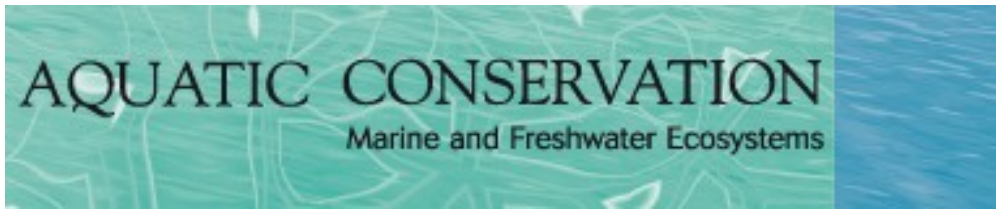

\title{
The effects of marine protected areas on ecosystem recovery and fisheries using a comparative modelling approach
}

\begin{tabular}{|c|c|}
\hline Journal: & Aquatic Conservation: Marine and Freshwater Ecosystems \\
\hline Manuscript ID & AQC-19-0295.R1 \\
\hline Wiley - Manuscript type: & Research Article \\
\hline $\begin{array}{r}\text { Date Submitted by the } \\
\text { Author: }\end{array}$ & $\mathrm{n} / \mathrm{a}$ \\
\hline Complete List of Authors: & $\begin{array}{l}\text { Vilas, Daniel; University of Florida Institute of Food and Agricultural } \\
\text { Sciences, Nature Coast Biological Station; University of Florida School of } \\
\text { Forest Resources and Conservation, Fisheries and Aquatic Sciences } \\
\text { Program; Institut de Ciències del Mar, Renewable Marine Resources } \\
\text { Coll, Marta; Institut de Ciències del Mar, Renewable Marine Resources; } \\
\text { Ecopath International Initiative } \\
\text { Corrales, Xavier; Institut de Ciències del Mar, Renewable Marine } \\
\text { Resources; Ecopath International Initiative; AZTI } \\
\text { Steenbeek, Jeroen; Ecopath International Initiative } \\
\text { Piroddi, Chiara; European Commission Joint Research Centre Ispra } \\
\text { Sector, Institute for Environment and Sustainability } \\
\text { Calò, Antonio; Université Côte d'Azur, CNRS, UMR ; Università di } \\
\text { Palermo Dipartimento di Scienze della Terra e del Mare } \\
\text { Di Franco, Antonio; Université Côte d'Azur, CNRS, UMR ; Stazione } \\
\text { Zoologica Anton Dohrn, Dipartimento Ecologia Marina Integrata, Sede } \\
\text { Interdipartimentale della Sicilia } \\
\text { Font, Toni; Universitat de Girona Facultat de Ciencies } \\
\text { Guidetti, Paolo; Université Côte d'Azur, CNRS, UMR } \\
\text { Ligas, Alessandro; Consorzio per il Centro Interuniversitario di Biologia } \\
\text { Marina ed Ecologia Applicata G. Bacci, } \\
\text { Lloret, Josep; Universitat de Girona Facultat de Ciencies, Institute of } \\
\text { Aquatic Ecology } \\
\text { Prato, Giulia; WWF Italy } \\
\text { Sahyoun, Rita; WWF France } \\
\text { Sartor, Paolo; Consorzio per il Centro Interuniversitario di Biologia } \\
\text { Marina ed Ecologia Applicata G. Bacci } \\
\text { Claudet, Joachim; National Centre for Scientific Research, CRIOBE }\end{array}$ \\
\hline $\begin{array}{l}\text { Broad habitat type } \\
\text { (mandatory) select 1-2: }\end{array}$ & coastal < Broad habitat type \\
\hline $\begin{array}{l}\text { General theme or application } \\
\text { (mandatory) select } 1-2 \text { : }\end{array}$ & $\begin{array}{l}\text { ecosystem approach }<\text { General theme or application, modelling }< \\
\text { General theme or application }\end{array}$ \\
\hline $\begin{array}{l}\text { Broad taxonomic group or } \\
\text { category (mandatory, if } \\
\text { relevant to paper) select } 1-2 \text { : }\end{array}$ & fish $<$ Broad taxonomic group or category \\
\hline
\end{tabular}


Impact category (mandatory,

if relevant to paper) select 1 - fishing < Impact category

\section{SCHOLARONE ${ }^{m}$ Manuscripts}


1 The effects of marine protected areas on ecosystem recovery and fisheries

2 using a comparative modelling approach

3

4 Authors

5 Daniel Vilas ${ }^{* 1,2,3}$, Marta Coll1,4, Xavier Corrales ${ }^{1,4,5}$, Jeroen Steenbeek ${ }^{4}$, Chiara

6 Piroddi $^{6}$, Antonio Calò ${ }^{7,8}$, Antonio Di Franco 7,9 , Toni Font ${ }^{10}$, Paolo Guidetti ${ }^{7}$,

7 Alessandro Ligas ${ }^{11}$, Josep Lloret ${ }^{10}$, Giulia Prato ${ }^{12}$, Rita Sahyoun ${ }^{13}$, Paolo Sartor ${ }^{11}$

8 and Joachim Claudet ${ }^{14}$

$9 \quad$ Affiliations

$10{ }^{1}$ Institut de Ciències del Mar (ICM-CSIC), P. Marítim de la Barceloneta, 37-49,

1108003 Barcelona, Spain.

122 Nature Coast Biological Station, Institute of Food and Agricultural Sciences,

13 University of Florida, Cedar Key, FL 32625, United States.

$14{ }^{3}$ Fisheries and Aquatic Sciences Program, School of Forest Resources and

15 Conservation, University of Florida, Gainesville, FL 32611, United States.

$16{ }^{4}$ Ecopath International Initiative (EII), Barcelona, Spain.

$17{ }^{5}$ AZTI, Marine Research, Txatxarramendi Ugartea z/g, E-48395, Sukarrieta, Spain.

$18{ }^{6}$ European Commission, Joint Research Centre, Institute for Environment and

19 Sustainability, Via Fermi 2749, 21027 Ispra, Italy.

207 Université Côte d'Azur, CNRS, UMR 7035 ECOSEAS, Parc Valrose 28, Avenue

21 Valrose, 06108, Nice, France.

228 Dipartimento di Scienze della Terra e del Mare (DiSTeM), Università di Palermo,

23 Via Archirafi 20, 90123 Palermo, Italy.

249 Stazione zoologica Anton Dohrn, Dipartimento Ecologia Marina Integrata, Sede

25 Interdipartimentale della Sicilia, Lungomare Cristoforo Colombo (complesso

26 Roosevelt), 90142 Palermo, Italy.

2710 Universitat de Girona, Girona, Spain. 
28

29

30

31

32

33

34

35

36

37

38

39

40

41

42

43

44

45

46

47

48

49

50

51

52

53

54

6

${ }^{11}$ Consorzio per il Centro Interuniversitario di Biologia Marina ed Ecologia

Applicata "G.Bacci”, viale N. Sauro 4, 57128, Livorno, Italy.

12 WWF Italy, Italy.

${ }^{13}$ WWF France, 35-37 rue Baudin - 93310 Le Pré-Saint-Gervais - France.

${ }^{14}$ National Center for Scientific Research, PSL Université Paris, CRIOBE, USR

3278 CNRS-EPHE-UPVD, Maison des Océans, 195 rue Saint-Jacques 75005

Paris, France.

7

8

9

\section{Abstract}

1. The overexploitation of many marine resources and ecosystems calls for the development and implementation of measures to support their recovery and conservation.

2. The potential contributions to support fisheries and ecosystem recovery were assessed at the local level of the three multiple-use Marine Protected Areas (MPAs) of Cerbère-Banyuls, Medes Islands and Cap de Creus, located in the Northwestern Mediterranean Sea.

3. For each MPA, a food-web model accounting for each protection level (PL) was developed: the fully protected area (FPA), the partially protected area (PPA) and the unprotected area (UPA) surrounding the MPA. Using the resulting nine food-web models, the ecosystem structure and functioning of each PL were compared and characterized, differences and similarities within and among the three MPAs were assessed, and ecosystem response to fully protection was evaluated for the three MPAs. 
4. Differences in terms of ecosystem structure and functioning were found among PLs. Overall, FPAs presented the most positive effect of protection in terms of ecosystem structure and functioning, followed by PPAs. However, the effects of protection on neighbouring unprotected areas were hardly noticeable.

5. Similarities between Cerbère-Banyuls and Medes Islands MPAs were observed, while Cap de Creus MPA showed the least benefits from protection overall. These results are likely due to similarities in the configuration of the protected areas, the levels of enforcement and compliance, and the impact of recreational and small scale fisheries allowed in the PPAs and UPAs.

6. This study illustrates that well-enforced Mediterranean MPAs, even when small, can yield local positive impacts on the structure and functioning of marine ecosystems that can contribute to support local fisheries.

Keywords: Protection levels, fully protected areas, partially protected areas, Ecopath with Ecosim, NW Mediterranean Sea

*Contact author: danielvilasgonzalez@gmail.com 


\section{Introduction}

Marine ecosystems have been degraded at high rates under the cumulative impact of multiple anthropogenic activities (Costello et al., 2010; Halpern et al., 2015). In 2010, the United Nations' Convention on Biological Diversity (CBD) established a target of $10 \%$ of the ocean to be protected by 2020 ("Aichi Target 11") (CBD, 2010). Marine protected areas (MPAs hereafter) are an essential tool for reversing the global degradation of ocean life (Claudet et al., 2008; Babcock et al., 2010; McCauley et al., 2015). Several studies have shown that protection from fishing leads to rapid increases in abundance, size and biomass of exploited species and, sometimes, to an increase in species diversity (e.g. Claudet et al., 2010; Di Franco et al., 2018; Lester et al., 2009). However, only $3.7 \%$ of the world's ocean is currently protected with MPAs (Sala et al., 2018).

MPAs can also provide socio-economic benefits. Economic benefits may stem from the creation of employment opportunities through the development of nonconsumptive activities such as tourism and recreation (Roncin et al., 2008), or from securing future jobs by increasing the chances of managing stocks sustainably (Sumaila et al., 2000). Fisheries benefits arise from ecological effects within protected areas in the form of biomass recovery, and subsequent spillover outside the boundaries of the MPA (Di Lorenzo et al., 2016) or by increased larval production and supply to unprotected areas (Marshall et al., 2019), with MPAs finally replenishing external fisheries grounds. Actually, empirical studies comprising small scale (Stelzenmüller et al., 2008), recreational (Font et al., 2012a) and industrial bottom-trawling fishing effort (Murawski et al., 2005) showed a concentration of fishing activities in the close vicinity of the MPA boundaries. This concentration of fishing effort, also known as "fishing the line", can reduce the biomass in neighbouring unprotected areas.

Most MPAs are multiple-use (Claudet, 2018). They combine different levels of protection within a spatially zoned management scheme that can encompass fully protected areas (FPA, also known as no-take areas), where all extractive activities are prohibited, or a type of partially protected areas (PPAs), where some fishing 
102

103

104

105

106

107

108

109

110

111

112

113

114

115

116

117

118

119

120

121

122

123

124

125

126

127

128

129

130

activities are allowed but with varying restrictions (Lubchenco and Grorud-Colvert, 2015; Horta e Costa et al., 2016; Giakoumi et al., 2017). Multiple management uses in MPAs can have strong implications in terms of ecosystem and fisheries benefits at the larger scale (i.e. regional). Recent studies showed that ecological benefits can be observed in fully and highly protected areas, while lower levels of protection provide benefits only under specific conditions (i.e. when surrounded by a fully protected area; (Zupan et al., 2018b). In addition, when allowed in a given zone of an MPA, fishing exploitation can become a threat for the overall MPA (Zupan et al., 2018a).

While MPAs are an ecosystem-based management tool, it is still unclear how the functioning of ecosystems is affected by protection - in particular, how different levels of protection in multiple-use MPAs translate into ecosystem reorganizations, and how ecosystem response to different levels of protection transfer into fisheries benefits. Here, using food-web modelling techniques, different levels of protection in multiple-use MPA were quantitatively modeled and their ecosystem structural and functional trait responses were compared. Three Mediterranean MPAs were used as case studies to develop ecosystem models for each protection level in each MPA.

\section{Material \& Methods}

\section{Study areas}

Different protection levels (PLs) in three MPAs in the North-western Mediterranean Sea were examined: Cerbère-Banyuls MPA in France, Cap de Creus and Medes Islands MPAs in Spain (Figure 1). A PL was identified as an area included in an MPA or its surroundings which is classified by its level of protection (fully, partially or unprotected).

These three MPAs were selected because of their similar bathymetric ranges, habitat composition, spatial proximity, and because each MPA combines different levels of protection within a spatially zoned management scheme (Table 1 and Figure 1). Each of the three MPAs has a fully protected area (FPA) at its core, where fishing is not allowed. Neighbouring partially protected areas (PPAs) allow restricted 
131 uses such as small-scale (traditional/artisanal) fisheries (Zupan et al., 2018a). Last, 132 unprotected areas (UPAs) surround each MPA.

133

134

135

136

137

138

139

140

141

142

143

144

145

146

147

148

149

150

151

152

153

154

155

156

157

In order to model the functioning of each MPA and the influence of the protected area on the unprotected area, the FPA, PPA and UPA zones in isolation were modelled. The boundaries of UPAs were selected as all areas adjacent to the MPA with similar ecological characteristics (Figure 1).

\section{Ecosystem modelling approach}

PL models were developed using the Ecopath with Ecosim approach (EwE 6.6 version) (Christensen and Walters, 2004; Christensen et al., 2008) and followed the best practices rules (Heymans et al., 2016).

Ecopath is a mass-balanced model based on two main equations. The first master equation describes the energy balance for each functional group in the model, so that:

$$
\text { Consumption }=\text { production }+ \text { respiration }+ \text { unassimilated food } \quad \text { Eq. } 1
$$

The second Ecopath equation is based on the assumption that the production of one functional group is equal to the sum of all predation, non-predatory losses, exports, biomass accumulations, and catches, as expressed by the following equation:

$$
P / B_{i} \cdot B_{i}=P / B_{i} \cdot B_{i} \cdot\left(1-E E_{i}\right)+\sum_{j}(Q / B)_{j i} \cdot B_{i} \cdot D C_{j i}+Y_{i}+N M_{i}+B A_{i} \quad \text { Eq. } 2
$$

where $B_{i}$ is the biomass, $(P / B)_{i}$ is the production rate, $(Q / B)_{i}$ is the consumption rate, $D C_{j i}$ is the fraction of prey $i$ included in the diet of predator $j, N M_{i}$ is the net migration of prey $i, B A_{i}$ is the biomass accumulation of prey $i, Y_{i}$ is the catch of prey $i$, and $E E_{i}$ is the ecotrophic efficiency of prey $i$, that is, the proportion of production used in the system or exported.

\section{Model parametrization}

An ecosystem model was built for each protection level, i.e. for each combination of the three MPAs and three protection levels (FPA, PPA and UPA). 
158 The nine PL models were built using the best available information and represented 159 periods from 2000 s to 2010 s, mostly limited by the available biomass data from the 160 underwater visual census (UVC). Specifically, the Cerbère-Banyuls MPA model 161 included most of the data from 2013, while the Cap de Creus MPA and the Medes 162 Islands MPA models included most of their information from the period (2005-2008) 163 and (2000-2004), respectively.

164 165 166 167 168 169

170

171

172

173

174

175

176

177

178

179

180

181

182

183

184

185

Species presence and their biomass were aggregated in functional groups (FGs) of species or groups of species clustered according to their trophic ecology, commercial value, and abundance in the ecosystem. The meta-web structure previously defined for the Western Mediterranean Sea model (Coll et al., 2019) developed under the SafeNet Project $^{1}$ context was followed. This meta-web structure was adapted to local conditions, removing those FGs which did not occur in the study areas. The final food-web structure of Cerbère-Banyuls MPA contained 64 functional groups (two marine mammals, three seabirds, one sea turtle, eight pelagic fish, 25 demersal fish, three cephalopods, 14 invertebrates, 2 primary producers, two zooplankton, two phytoplankton and two detritus), while Cap de Creus MPA and Medes Islands MPA had 67 functional groups each (two marine mammals, three seabirds, one sea turtle, nine pelagic fish, 25 demersal fish, three cephalopods, 14 invertebrates, four primary producers, two zooplankton, two phytoplankton, and two detritus) (supplementary material Table S1.1). Except in the case of FPAs, which do not have discards because all fishing extractions are forbidden, food-web structures of each PL in the same MPA were identical.

FGs' biomass were obtained from different sources from the study area or surrounding areas (see supplementary material Table S2.1. for details on the parameterization of each functional group). The nine PL models share biomass data on some FGs (marine mammals, seabirds, sea turtles, pelagic fish, some invertebrates' groups, primary producers, zooplankton and phytoplankton) for two main reasons: the lack of local data and/or the closeness among these MPAs. The

${ }^{1}$ http://www.criobe.pf/recherche/safenet/ 
186

\section{7}

188

189

190

191

192

rest of the FGs were parameterized with local information available from field studies for Cerbère-Banyuls (underwater visual census, UVC) (Claudet, 2013) and literature for Cap de Creus and Medes Islands models (García-Rubies and Zabala i Limousin, 1990; Macpherson et al., 2002; Hereu Fina and Quintana Pou, 2012; Hereu Fina et al., 2017) (supplementary material Table S2.1.) except for some non-reef fish and invertebrates' FG. For these non-reef fish FG (e.g. anglerfish), MEDITS trawling survey (Bertrand et al., 1997) data were extracted with a new software developed for SafeNet Project, MEDITS data explorer v. 1.5.1 (Steenbeek, 2018a). This tool allowed us to extract MEDITS data easily, and to scale biomass data to the area and bathymetric ranges. MEDITS trawling survey data were extracted from the closest point to each MPA, in order to have biomass data for those species that were not present during field studies. Those species are present in the MPAs, but they are less important in MPAs in terms of biomass. This assumption was assessed previously with expert knowledge from the project. For invertebrates' FGs whose biomass estimates were not available, realistic EE values were used to estimate the biomass of four FGs in Cerbère-Banyuls models and six FGs in Cap de Creus and Medes Islands models (supplementary material Table S2.2.). Additionally, scaling factors were used on biomass data of pelagic fish groups available from the MEDITS oceanographic survey, which does not fully cover coastal areas. Thus, this scaling enabled to adapt the estimates and get more accurate biomass values for these coastal areas. The scaling conversions were based on species depth distribution (extracted from Aquamaps - www.aquamaps.org) (Kaschner et al., 2013) and took into account their contribution in each FG.

Production $(P / B$, year-1) and consumption $(Q / B$, year-1) rates were either estimated using empirical equations (Heymans et al., 2016), taken from literature or from other models developed in the Mediterranean Sea (Coll et al., 2019) (supplementary material Table S2.1). Additionally, local body lengths of reefassociated species obtained from UVC (Di Franco, 2018) were used to estimate P/B and Q/B rates using empirical equations and local data (Pauly, 1980). 
217 on stomach content analyses, giving preference to local or surrounding areas 218 (supplementary material Table S2.1.). Diet Matrix Calculator (Steenbeek, 2018b), a 219 custom-build extraction tool, was used to automatize the process of selecting and 220 scaling diet data. Drawing on a large library of published diet studies, the Diet matrix 221 calculator tool selects the most likely suitable diet studies for a specific model area, 222 based on a range of criteria, and generates a diet composition matrix with 223 accompanying pedigree index for each predatory functional group. Due to the small 224 sizes of the PLs investigated and the capacity of some species to move between 225 PLs (Gell and Roberts, 2003a; Grüss et al., 2011), a fraction of the diet composition 226 of these species was set as import for all PLs based on the time that these species 227 feed outside the areas and their ecological traits. This import was based on the size, 228 behaviour, and ecology of species of each functional group (Froese and Pauly, 229 2019).

230 Fisheries data were obtained from different sources (database, literature and 231 unpublished data) (supplementary material Table S2.1) and the information on 232 catches was split into two fishing fleets - recreational and professional small scale 233 (except for FPA models where fishing activities are not allowed). Regarding 234 professional small scale fisheries catches, Cerbère-Banyuls data were obtained from 235 a local study (Prats, 2016), while for Cap de Creus and Medes Islands the data 236 came from an official dataset of the regional government of Catalonia managed by 237 the Institute of Marine Sciences (ICM-CSIC) (Tudó, 2017). For Cap de Creus, these 238 landings were from Llançà, Port de la Selva, Cadaqués and Roses harbours, where 239 the main fleets operating are located, and were scaled by the months of fishing 240 activity of the fleets inside the MPA (Gómez et al., 2006). For recreational fisheries, 241 catches were extracted from Ivanoff et al. (2010) in Cerbére-Banyuls. Cap de Creus 242 recreational catches came from Font and Lloret (2011a, 2011b) and Lloret et al. 243 (2008a, 2008b). Whereas, for Medes, recreational catches were extracted from 244 Sacanell (2012). 
247

248

249

250

251

252

253

254

255

256

257

258

259

260

261

262

263

264

265

266

267

268

269

270

271

272

273

274

275

In an Ecopath model, the energy input and output of all functional groups must be balanced under ecological and thermodynamic rules: (1) EE < 1.0; (2) P/Q [production/consumption rate or gross efficiency (GE)] should range from 0.1 to 0.3 with the exception of fast-growing groups such as bacteria; (3) R/A (respiration/food assimilation) < 1; (4) R/B (respiration/biomass) should range from 1 to 10 for fish and higher values for small organisms; (5) NE (net efficiency of food conversion) > GE and (6) P/R (production/respiration) < 1 (Christensen et al., 2008; Heymans et al., 2016). A standardized procedure to ensure the mass-balance of all the models was followed (detailed information can be found at Appendix 5 in the supplementary material).

The quality of the models was evaluated using the pedigree routine, which allows assigning a pedigree value for each input parameter $(B, P / B, Q / B$, diet and catches) (Christensen and Walters, 2004; Christensen et al., 2008). All pedigree values were established manually except for diet pedigree values, which were obtained from the Diet Calculator software (Steenbeek, 2018b). This software computes a total pedigree value for each diet record, which is a weighted average of four field scores from four diet features (region, year, type of data and method). Pedigree values were first used to determine which parameters were of lower quality and thus could be modified during the balancing procedure. Afterwards, they were used to calculate the pedigree index of each model, which vary between 0 (lowest quality) and 1 (highest quality) (Christensen and Walters, 2004).

\section{Models analyses and ecological indicators}

The food-web structure of each PL in the three MPAs was visualized using a flow diagram. Flow diagrams were obtained using the ggplot2 package (Wickham, 2010) implemented in $R$ software ( $R$ Core Team, 2017) and were built from the biomass, trophic levels (TL, as outputs) of each FG, and the direct trophic interactions among them extracted from EwE. The TL identifies the position of organisms within food webs by tracking the source of energy for each organism, and it is calculated by assigning primary producers and detritus a TL of 1 (e.g. 
276 phytoplankton), and consumers to a TL of 1, plus the average $T L$ of their prey 277 weighted by their proportion in weight in the predator's diet (Christensen, 1996).

278

279

280

281

282

283

284

285

286

287

288

289

290

291

292

293

294

295

296

297

298

299

300

301

302

303

304

305

306

To describe the state and functioning of the ecosystems, several ecological indicators were derived from modeling procedure. A detailed explanation of the equations to calculate these indicators are described in Christensen et al. (2008) and Coll and Steenbeek (2017). These indicators were divided into five main groups following:

- Biomass-based indicators are calculated from the biomass of components. Species biomass data are considered basic information to evaluate effectiveness in marine protected areas (Micheli et al., 2004), so it is expected that the higher biomass-based indicator value, the more restrictive protection levels and enforced MPAs are. Four biomass-based indicators were included: total biomass $\left(\mathrm{t} \cdot \mathrm{km}^{-2}\right)$, biomass of commercial species $\left(\mathrm{t} \cdot \mathrm{km}^{-2}\right)$, biomass of fish species $\left(\mathrm{t} \cdot \mathrm{km}^{-2}\right)$, and Kempton $\mathrm{Q}$ diversity index.

- Trophic-based indicators reflect the TL position of different groups of the food web. Trophic level indicators may reflect ecosystem "health" because fishing pressure resulting in the removal of predators can cause a decline in the trophic level of the catch and/or the community (Christensen and Walters, 2004). Therefore, the higher TL and trophic-based indicators estimates are found in the more restrictive protection levels and enforced MPAs. Four trophic-based indicators were selected: TL of the community (TLc), TL of the community including organisms with $T L \geq 2$ (TL2), TL of the community including organisms with $T L \geq 3.25$ (TL3.25) and TL of the community including organisms with TL $\geq 4$ (TL4) (Pauly and Watson, 2005).

- Species and size-based indicators are based on species traits and conservation status. Increase in species traits such as mean length can be a direct effect of marine protected areas (Claudet et al., 2006), and therefore higher values are expected for more restrictive protection levels and enforced MPAs Three species-based indicators were selected: biomass of species that are included in the IUCN Red List - Mediterranean regional assessment (www.iucnredlist.org) as threatened (i.e. critically endangered, endangered 
307

308

309

310

311

312

313

314

315

316

317

318

319

320

321

322

323

324

325

326

327

328

329

330

331

332

333

334

335

336

337

and vulnerable) and near threatened $\left(\mathrm{t} \cdot \mathrm{km}^{-2}\right.$.year-1 $)$, mean length $(\mathrm{ML})$ of fish in the community $(\mathrm{cm})$ and mean life span (MLS) of fish in the community (year).

- Flow-based indicators are related to the interactions in the network of the system and six were selected. The Total System Throughput (TST, $t \cdot \mathrm{km}^{-}$ 2. year $^{-1}$ ) is the sum of all flows in the model and it is considered an overall measure of the "ecological size" of the system (Finn, 1976). The Finn's Cycling Index $(\mathrm{FCl}, \%)$ is the fraction of the ecosystem's throughput that is recycled (Finn, 1976). The Average Path Length (APL) is defined as the average number of groups that flows pass through and is an indicator of stress (Christensen, 1995). Therefore, the higher $\mathrm{FCl}$ and $\mathrm{APL}$ values are, the more resilient, stable and mature the ecosystem is (Christensen, 1995). Additional indicators were selected because of their information on the distribution of ecosystem flows and their robustness in front of models' comparison (Heymans et al., 2014) and: the ratios of consumption (Q), export (Ex) and production $(\mathrm{P})$.

- Catch-based indicators are focused on the fishing activity and based on catch and discard data. They can give an idea of the potential effect on adjacent fisheries through spillover of exploited fishes from FPAs (McClanahan and Mangi, 2000), so greater catch-based indicators values are expected on wellenforced MPAs. Also, PPA is usually surrounding FPAs and is where higher fishing pressure levels occur (Stelzenmüller et al., 2008), so catch-based indicators are supposed to be higher in these areas. Six indicators were included: total catch $\left(\mathrm{t} \cdot \mathrm{km}^{-2}\right.$.year $\left.{ }^{-1}\right)$, total discarded catch $\left(\mathrm{t} \cdot \mathrm{km}^{-2} \cdot \mathrm{year}^{-1}\right), \mathrm{TL}$ of the catch, the intrinsic vulnerability index of catch, ML of fish in the catch $(\mathrm{cm})$ and MLS of fish in the catch (year).

Additionally, the mixed trophic impact (MTI) analysis was performed to quantify direct and indirect trophic interactions among functional groups (Ulanowicz and Puccia, 1990). This analysis quantifies the direct and indirect impacts that a hypothetical increase in the biomass of one functional group would have on the biomass of all the other functional groups, including the fishing fleets. The MTI for 
338 living groups is calculated by constructing an $\mathrm{n} \times \mathrm{n}$ matrix, and quantifying each 339 interaction between the impacting group (j) and the impacted group (i) is:

$$
M T I_{j i}=D C_{j i}-F C_{i j}
$$

341 where $D C_{j i}$ is the diet composition term expressing how much $i$ contributes to the diet 342 of $j$, and $F C_{i j}$ is a host composition term giving the proportion of the predation on $j$ 343 that is due to $i$ as a predator.

Furthermore, keystoneness analysis was performed for the nine protection 345 levels. A keystone species is a species that shows relatively low biomass but has a 346 relatively important role in the ecosystem (Power et al., 1996). To identify the 347 keystone species within the ecosystem, the keystoneness index (KS) of the most 348 important reef FG (common pandora: Pagellus erythrinus; Sparidae; white 349 seabream: Diplodus sargus; common two-banded seabream: Diplodus vulgaris; 350 Common dentex: Dentex dentex; red scorpionfish: Scorpaena scrofa; groupers: 351 Epinephelus spp; brown meagre: Sciaena umbra; Labridae and Serranidae; Other 352 commercial medium demersal fish; salema: Salpa salpa; Mugilidae; red mullet: 353 Mullus barbatus; and striped red mullet: Mullus surmuletus) were estimated using 354 Valls et al. (2015) (KS $)$ keystoneness index, in which the biomass component is 355 based on a descending ranking. These indices are calculated as:

$357 \quad K S_{V i}=\log \left[I C_{i} \cdot B C_{i}\right]$ Eq. where $I C_{i}$ is a component estimating the trophic impact of the group $i$; and $B C_{i}$ is a 360 component estimating the biomass of the group $i$.

\section{Evaluating MPAs and the role of PLs}

In order to determine the role of PLs in the functioning of the MPAs, results 363 from ecological indicators (except catch-based indicators) and keystoneness were 364 compared among the three PLs within each MPA. This comparison among PLs 
365

366

367

368

369

370

371

372

373

374

375

376

377

378

379

380

381

382

383

384

385

386

387

388

389

390

391

ecological indicators served to capture shifts in ecosystem structure and functioning due to the level of protection (Dale and Fortin, 2014).

The same above-mentioned indicators were used to evaluate differences among the three studied MPAs, comparing the same PLs of the different MPAs. For instance, considering the FPAs of the three MPAs allowed us to capture how different are these MPAs even although they officially offer the same levels of protection. Despite that each MPA differs in the restrictions in their PPAs, this multiple comparison procedure was developed for the three PLs because ecological theory establishes that reserve effects should extend from FPA beyond its boundaries as a result of spillover (Gell and Roberts, 2003b).

\section{Impact of small-scale fisheries}

To evaluate the impact of small-scale fisheries on the MPAs, catch-based indicators were examined between PPAs and UPAs of the three MPAs. The mixed trophic impact results of recreational and professional small scale fishing fleets were examined to quantify the direct and indirect impact of each fleet on the functional groups for PPAs and UPAs of the three studied MPAs, and their potential competition and trade-offs between them were identified.

\section{Results}

The pedigree index values of the PL models showed similar values among them (Figure 2), ranging from 0.41 to 0.52 . The highest pedigree values were obtained for Cerbère-Banyuls, and FPAs had slightly lower pedigree indexes than the other PLs.

The flow diagrams displayed high levels of biomass even for some high trophic level groups, especially in the FPAs (Figure 3 and supplementary material Figure S6.1). Also, the results highlighted the complexity of these food webs with respect to the number of trophic links among functional groups with important fluxes of energy from phytoplankton and detritus up the food web.

\section{Ecosystem structure and functional traits}


392

393

394

395

396

397

398

399

400

401

402

403

404

405

406

407

408

409

410

411

412

413

414

415

416

417

418

419

420

Overall, biomass-based indicators displayed the same pattern between PLs (Figure 4), with the highest biomass values found in Cerbère-Banyuls, then Medes Islands and finally Cap de Creus. Conversely, the Kempton's biodiversity index decreased from Cap de Creus to Medes Islands and then Cerbère-Banyuls. Within PLs, the FPAs showed the highest values in terms of total and fish biomass, and they were followed by the PPA in all MPAs. In Cap de Creus similar values were observed among PLs for total, fish and commercial biomass. Kempton's biodiversity index values were similar among PLs for Cerbère-Banyuls, while the highest value was obtained by the UPA for Medes Islands and the FPA for Cap de Creus.

Trophic-based indicators revealed that the TL of the community and TL2 was higher for Cerbère-Banyuls, followed by Medes Islands, while Cap de Creus showed the lowest levels (Figure 5). Cerbère-Banyuls and Medes Islands displayed similar values for TL3.25 and TL4, while Cap de Creus showed higher variance among these indicators. Specifically, Cap de Creus showed the highest TL3.25 values and the lowest TL4 value. Within PLs, most trophic-based indicators showed the highest values for FPAs followed by PPAs and UPAs. However, the FPA in Cap de Creus displayed the lowest value of TL4 (Figure 5).

Flow-based indicators showed differences between MPAs. Cerbère-Banyuls showed the highest values for Q/TST, TST, FCl, and APL, while the lowest values for Ex/TST and P/TST (Figure 6). In contrast, Cap de Creus showed the lowest values for $Q / T S T$, whilst the highest values were observed for Ex/TST and P/TST. Medes Islands MPA values were located between these two MPAs. Considering PL values, flow-based results revealed higher values for FPAs followed by PPAs in most of the flow-based indicators. As an exception, Ex/TST and P/TST were higher for UPAs and lower for FPAs.

Results from species and size-based indicators (Figure 7) revealed that Cerbère-Banyuls had the highest values for IUCN species biomass, followed by Medes Islands. Regarding ML and MLS of fish, the highest values were also obtained for Cerbère-Banyuls, followed by Cap de Creus and then Medes Islands. 
421 Species and size-based indicators were higher for FPAs, except in Cap de Creus, 422 where PPA had higher values of ML and MLS than FPA.

423

424

425

426

427

428

429

430

431

432

433

434

435

436

437

438

439

440

441

442

443

444

445

446

447

448

449

450

The keystoneness index (Figure 8; Supplementary material Appendix 4) for the nine models identified as keystone functional groups: groupers, other commercial medium demersal fish, common dentex and Labridae \& Serranidae. Particularly, groupers had the highest relative total impact. These results confirmed that groupers play an important ecological role in Mediterranean coastal ecosystems. The keystoneness index showed different patterns among PLs and MPAs. Medes Islands models had the highest number of keystone species followed by Cerbère-Banyuls (Figure 8 ).

\section{Role and impact of small-scale and recreational fisheries}

Total catch and discards showed similar values between Cap de Creus and Medes Islands, while Cerbère-Banyuls presented the lowest values (Figure 9). Vulnerability index values were similar for Cap de Creus and Cerbère-Banyuls, with the lowest value found for Medes Islands. TL of the catch was higher for CerbèreBanyuls and Cap de Creus and lower for Medes Islands (Figure 9), and these results are in line with MLS of the catch results (Figure 7). Also, Cerbère-Banyuls showed the highest value for MLc while Cap de Creus had the lowest value. TC and discards exhibited higher values for PPAs than UPAs. IV indexes were higher for PPAs than UPAs except for Cerbère-Banyuls. The catch TL values were similar between PPA and UPA in Cap de Creus and Medes Islands, while it was higher for PPA in CerbèreBanyuls. ML and MLS of the catch results showed similar values between PLs for Medes Islands, while PPA showed higher values in Cap de Creus and lower in Cerbère-Banyuls.

Overall, the MTI analysis based on fisheries did not show any pattern among PLs and MPAs, and fisheries impacting values were clearly higher and more fluctuating than impacted values. Mostly, the highest impacts of recreational fisheries were found for the PPA of Cap de Creus, while the highest impacts of smale scale fleet were found for Cerbère-Banyuls. Specifically, MTI analysis revealed that the impacts of recreational fisheries were greater (positively and negatively) for brown 
451 meagre and groupers. On the other hand, the recreational fishery was highly 452 (positively) impacted by other commercial medium demersal fish and Sparidae 453 (Figure 10). Regarding small scale fishery, brown meagre, other commercial medium 454 demersal fish and red mullet were positively impacted by recreational fisheries, while 455 common dentex and groupers were negative impacted (Figure 11). Groupers was 456 the most impacting (negatively) group on the small scale fishery. Recreational and 457 small scale fisheries showed low impacted and impacting values between them. 458 Among them, the highest impact was for the recreational fleet on the small scale one 459 in the PPA of Cap de Creus.

460

461

462

463

464

465

466

467

468

469

470

471

472

473

474

475

476

477

478

479

480

\section{Discussion}

Nine quantitative models were built to investigate the differences among PLs of three MPAs in the NW Mediterranean Sea. This analysis allowed us to assess the impact of protection on the ecosystem at local scale. The input data were qualitatively acceptable if our results are compared to the distribution of pedigree values in other existing models (Morissette, 2007; Lassalle et al., 2014). Also, the pedigree values of the models were comparable to that from other available MPA models in the Western Mediterranean Sea, such as 0.49 in the Portofino MPA (Prato et al., 2016). However, FPAs showed the lowest pedigree values because several $\mathrm{P} / \mathrm{B}$ parameters were estimated to obtain reasonable $\mathrm{P} / \mathrm{Q}$ values (Heymans et al., 2016) and so decreasing their pedigree index. These results highlighted the need to develop studies focused on estimating specific growth and consumption ratios for species in Mediterranean MPAs.

The flow diagram showed the first differences among PLs. Although TLs were similar among three PLs in each MPA, some commercial functional groups (e.g. FG 26 - groupers in Cerbère-Banyuls) showed slightly higher values for FPAs. This pattern could be due to the effect of protection in these areas, which may be connected with the complexity of the food web and the maturity of the ecosystem (Odum and Barrett, 1971).

Ecological indicators also showed differences among PLs and pointed at the strong benefits of FPAs (Sala et al., 2017). FPAs (also known as no-take areas) are 
481 widely recognized as a powerful tool for ecosystem and biodiversity conservation 482 (Claudet et al., 2008) and several studies have described their positive effects on 483 biomass (Guidetti et al., 2014), trophic levels (Prato et al., 2016), mean length 484 (Claudet et al., 2006), mean life span (Guénette and Pitcher, 1999), condition (Lloret 485 and Planes, 2003) and biomass of IUCN species such as groupers (Claudet et al., 486 2008). ). Not surprisingly, biomass and trophic-based indicators results increased 487 with the level of protection which demonstrated these positive effects of protection. 488 This implies that FPAs promote higher fish weight and marine species abundance 489 (Harmelin-Vivien et al., 2008). The increase in the TLs underlined the applicability of 490 FPAs as a conservation tool for large predatory fish species (Soler et al., 2015).

491 The same pattern was also found for TST, APL, and $\mathrm{FCl}$, in which the value 492 of the indicator increases with the level of protection. These indicators suggested 493 lower stress, more maturity, larger ecological size and higher resilience 494 (Christensen, 1995) for FPAs ecosystems. In line with these results, Sala et al. 495 (2017) highlighted the potential benefits of FPAs and pointed out that these areas 496 are more resilient than UPAs. In line with these results, consumption rate over total 497 system flows was higher in FPAs than PPA and UPA, since the higher the biomass 498 in the ecosystem the higher the consumption. Libralato et al. (2010) found similar 499 results for another Mediterranean MPA in the Adriatic Sea due to the effect of 500 protection. In addition, export and production ratio results showed higher values for 501 UPAs because the biomass of several FGs (such as Sparidae or groupers) were 502 quite high to support their feeding rates. So, these FGs would migrate beyond the 503 boundaries of the modelled ecosystem (PL) to maintain their feeding rates. The 504 export results are also related to the fact that fisheries occur in UPAs and PPAs in 505

506 Similarly, species based-indicators results showed a gradient among PLs. 507 reduces population abundance and mostly removing larger and older fish and so 508 decreasing the ML and MLS of fish in UPAs and increasing in the FPAs (Lizaso et 509 al., 2000). In addition, this pattern could also be due to large fish biomass with a 510 dominance of large apex predators such as Epinephelus marginatus (Hackradt et 
511 al., 2014). Similar results were found for several MPAs in the Mediterranean Sea 512 (Guidetti et al., 2014).

513 In addition, most biomass-based, trophic-based, species-based and flows514 based results obtained from PPAs demonstrated their role as buffer zones 515 (Giakoumi et al., 2017), so they may confer biomass enhancement compared to 516 UPAs although FPAs produce greater benefits (Lester and Halpern, 2008; Sciberras 517 et al., 2015). In addition, export and production ratio results showed higher values 518 for UPAs because the biomass of several FGs (such as Sparidae or groupers) were 519 quite high to support their feeding rates. So, these FGs would migrate beyond the 520 boundaries of the modelled ecosystem (PL) to maintain their feeding rates. The 521 export results are also related to the fact that fisheries occur in UPAs and PPAs in 522 comparison with FPAs, where they are forbidden.

523 In contrast, the Kempton's biodiversity index did not show the expected 524 pattern as biodiversity is expected to increase with protection (Costello and 525 Ballantine, 2015). This controversial result could be due to the available data, which 526 came from different studies for each MPA. The Kempton's biodiversity index may be 527 biased since Cerbère-Banyuls model differs on the number of functional groups 528 compared to Cap de Creus and Medes Islands model (Ainsworth and Pitcher, 2006). 529 Using multiple studies for each MPA could also bias this result because some studies 530 showed biomass estimates at higher taxonomic levels than others and the time 531 period that these models represent with regard to the creation year of the MPA. 532 Therefore, as more exhaustive species biomass data are available, the biodiversity 533 index becomes more reliable (Claudet, 2013; Hereu Fina et al., 2017). Although 534 some MPAs are not implemented for biodiversity purposes (Day et al., 2012), the 535 great differences of Kempton's biodiversity index between the FPA and the other 536 two PL areas in Cap de Creus could indicate that the PPA and the UPA marine 537 populations are not being replenished by new individuals coming from the FPA and 538 so not achieving the FPA's biodiversity value. The failure on the spillover effect in 539 Cap de Creus may be due to the lack of enforcement (Lloret et al., 2008a, 2008b), 540 high fishing pressure in the area (Lloret et al., 2008b) or the zonation and design of 
541 the MPA which is represented by a fragmented PPA and a non-totally surrounded 542 FPA.

543

544

545

546

547

548

549

550

551

552

553

554

555

556

557

558

559

560

561

562

563

564

565

566

567

568

569

570

571

Overall, indicators displayed differences among PLs within each MPA, especially in the case of Cerbère-Banyuls and Medes Islands MPAs, but not for Cap de Creus. Probably, these patterns could be explained by their enforcement, reported to be a key factor to promote direct and indirect reserve effects (Guidetti et al., 2008). The lack of enforcement is one of the most relevant issues concerning MPAs in the Mediterranean context (Fenberg et al., 2012). Claudet and Guidetti (2010) recognized that an MPA without enforcement and compliance is just a paper park and no reserve effects can be expected. This could be the case of Cap de Creus, in which our results did not show the same pattern found for the other two MPAs. In fact, Lloret et al. (2008a, 2008b) reported a lack of enforcement and a low level of compliance in Cap de Creus, particularly on minimum landing sizes of certain species and lack of fishing licenses. This is in contrast with Cerbère-Banyuls and Medes Islands MPAs, in which compliance and enforcement are ensured to promote a high level of ecological effectiveness (Di Franco et al., 2016). Our results are also consistent with previous studies performed in Cerbère-Banyuls (Harmelin-Vivien et al., 2008) and Medes Islands (Harmelin-Vivien et al., 2008; Sala et al., 2012), which demonstrated reserve effects for those MPAs and reported higher biomass in FPAs with a rapid decline from FPAs outward.

Giakoumi et al. (2017) revealed significant stronger biomass effect for FPAs than PPAs and higher fish density in older, better enforced, and smaller MPAs. Considering that Cap de Creus is the least enforced MPA in the study, our results suggest that the level of enforcement and compliance have a strong effect on MPA effectiveness at the ecosystem level. These patterns among MPAs were also found by Horta e Costa et al. (2016) who presented a novel classification system for MPAs which ranges from 1 (fully protected areas) to 8 (unprotected areas). In this scale, Cerbère-Banyuls obtained a rate of 4.7 , being a highly protected area, and Medes 6.4, being less well protected (Horta e Costa et al., 2016). Cap de Creus was not included in this study, but a higher MPA index can be assumed because of its small FPA and its low compliance which increases the impact of fishing activities. Overall, 
572 our results call for enhancement of the regulations, increasing the extent of FPAs 573 and the enforcement of management rules in Medes and Cap de Creus MPA.

$574 \quad$ All keystoneness indices for the nine models pointed at the same functional 575 groups as keystones. Among them, groupers and common dentex were highlighted 576 as keystone groups in previous western Mediterranean MPAs models (Valls et al., 577 2012; Prato et al., 2016).

578 MPAs are considered an important tool to manage coastal fisheries (Claudet 579 et al., 2006; Di Franco et al., 2016), and enforcement is a key aspect to achieve 580 these goals. Biomass and catch-based results demonstrated that well-enforced 581 small coastal MPAs can enhance small-scale and recreational fisheries by spillover 582 effect and can promote the sustainability of local fisheries (Forcada et al., 2009; Goñi 583 et al., 2011; Sala et al., 2013). According to the spillover effect, total catch and 584 discards were higher in PPAs than in UPAs for all MPAs. Additionally, these 585 differences on catches and discards between PPAs and UPAs can be explained by 586 the concept of "fishing the line", which can reduce the biomass in neighbouring 587 unprotected areas (Kellner et al., 2007), so understanding spatial-temporal patterns 588 of fishing effort around an MPA is a key aspect to manage and assess these areas. 589 In this context, Stelzenmüller et al. (2008) found a local concentration of fishing effort 590 around the borders of Cerbère-Banyuls and Medes Islands MPAs, in accordance 591 with our results. On the other hand, although small-scale and recreational fisheries 592 are often considered to have a relatively low ecological impact, they do affect 593 vulnerable species in coastal or offshore waters in the western Mediterranean Sea 594 (including MPAs) through, targeted fishing or unintentional bycatch (Lloret et al., 595 2019).

596 The results of PLs in Cap de Creus differed substantially from Cerbère597 Banyuls and Medes Islands. This could be related to the physical position of its FPA 598 within a multi-use MPA, which for Cap de Creus is not located at the core of the MPA 599 surrounded by PPAs as is the common MPA design in the Mediterranean Sea 600 (Gabrié et al., 2012). This unconventional placement could explain the observed 601 reduction in PPA effectiveness although this interpretation could be biased by the 
602 apparent lack of enforcement in Cap de Creus. In MPAs, the maximum benefit to 603 conservation and ecosystem services will occur when FPAs are surrounded by well604 managed fishing grounds (Roberts and Hawkins, 2000). This result suggested the 605 requirement of an implemented and non-fragmented PPA surrounding the FPA in 606 Cap de Creus which complements and ensures the protection of the biodiversity in 607 the FPA, as recommended in IUCN guidelines for applying MPAs (Day et al., 2012). 608 609 In addition, high values of total catch and discards in Cap de Creus could be related to non-compliance, as well as to the lack of georeferenced catch data that could have biased our results. Non-compliance could also result in some fishing inside FPAs and PPAs, which may reduce the effectiveness of their potential biological, ecological and fisheries benefits (Roberts, 2000), in accordance with the lack of enforcement obtained from other ecological indicators (e.g. biomass-based indicators). Additionally, vulnerability index and $\mathrm{ML}$ of the catch estimated values 615 from Cap de Creus could be explained as a failure in the enforcement in an MPA 616 supporting high fishing pressure from both small-scale and recreational fishing 617 sectors (Lloret and Font, 2013). Finally, our results highlighted the impact of 618 recreational fisheries in Cap de Creus among the rest of studied MPAs, which could 619 be also reducing MPA benefits (Lloret et al., 2008a, 2008b). On the other hand, the 620 lower values of total catch and discards, the higher values of TL of the catch, ML 621 and MLS of fish in the catch, could reveal potential benefits of protection to adjacent 622 fisheries. Fishing pressure can lead to a decrease of TL of the catch (Shannon et 623 al., 2014) and ML and MLS of fish in the catch (Pelletier et al., 2005). Similarly, Prato 624 et al. (2016) demonstrated that a decrease in the fishing effort lead to an increase 625 in the trophic level of the catch because of increasing in fish predators biomass in 626 Portofino MPA (Northwestern Mediterranean Sea).

628 contribution of PPAs to the recreational fishery. Although PPAs may differ in their 629 level of protection (Lester and Halpern, 2008), for example, spearfishing is not 630 allowed inside the PPA of Cerbère-Banyuls (Font et al., 2012b), these results 631 confirmed their ecological effects and benefits for adjacent fisheries. Regarding the 632 small scale fishery, the highest negative impacting values were represented by 
633 targeted species for this fleet, while positive values may represent FGs which are 634 preys of those targeted species. Cerbère-Banyuls obtained higher impacting values 635 than other MPAs. Since it is a well-enforced MPA, it could represent higher benefits 636 or catches than other MPAs. In addition, most highlighted FGs by their high 637 impacting values in small scale fishery matched with the keystone species, which 638 support that non-enforced marine protected areas may compromise positive effects 639 of these ecosystems (Claudet and Guidetti, 2010). Our results encourage fishermen 640 compliance, which was identified as a key attribute for fisheries' success such as in 641 Torre Guaceto MPA, where co-management involving fishers, scientists and 642 managers led to an increase in total fish biomass in FPA, an increase in fishermen's 643 revenues when they operate within the PPA and an increase in the commitment of 644 local fishermen to environmental issues (Di Franco et al., 2016).

645 646 647 648 649 650

The stronger benefits of FPAs than PPA and the importance of PPAs as a buffer area may suggest an alternative reorganization on the MPA zonation. An increase on the surface or percentage of area covered by FPA could lead to more resilient and productive MPAs which would enhance the benefits of ecosystem services including adjacent fisheries. Additionally, PPAs must be surrounding the FPA in order to ensure and complement the protection. Accordingly, MPA configuration may obtain greater benefits when increasing the FPA surface and ensuring its protection with a buffer PPA. MPAs and networks of MPAs can be used 653 to enhance the resilience, resistance in front perturbations or ecosystem 654 transformation in the face of climate change (Carr et al., 2017). MPA zonation allows 655 to assess the impacts of each protection level and accommodate multiple objectives, 656 human activities and stakeholder groups, and it is a key aspect of the management 657 of MPAs (Francour et al., 2001; Lester and Halpern, 2008).

658 Even though our work illustrates that quantitative food-web modelling 659 techniques can be useful to assess coastal MPAs effects on the structural and 660 functional traits of marine ecosystems and their adjacent fisheries, some limitations 661 were faced. One of the main hurdles was the lack of local data for some FGs 662 identified in previous MPA modelling studies (Libralato et al., 2010; Valls et al., 2012; 663 Prato et al., 2016). For example, literature including benthonic biomass estimations 
664 inside MPAs is mainly focused on sea urchins, gorgonians and Posidonia meadows 665 (e.g. Hereu Fina and Quintana Pou, 2012; Schvartz and Labbe, 2012). However, 666 studies on other important benthic groups such as sponges or crustaceans are 667 scarce. During the balancing procedure, higher predation mortalities were found for 668 several FGs in most quantitative models and diet imports were set in order to ensure 669 the mass-balance for each model. Although these import values were set 670 considering ecological and size attributes of each FGs, small and open study areas 671 could represent a limitation of our models due to the lack of data and knowledge. 672 Additionally, spatial-temporal series data of catches and fleet distribution would 673 improve the analysis on the effect of MPA potential benefits on the recreational and 674 small scale fisheries. Collecting time series of fishing activities surrounding MPAs is 675 a monitoring priority, as previously highlighted (Valls et al., 2012; Prato et al., 2016). 676 A recent published study (Lloret et al., 2019), which focused in the Northwestern 677 Mediterranean Sea, emphasized the importance of differentiating between fishing 678 methods or gears when studying the impacts on vulnerable species in MPAs which 679 could be accomplished if data are available. Moreover, our results could be biased 680 by the oceanographic conditions and the zonation of the modelled MPAs (Heymans 681 et al., 2016). In addition, and despite the fact that these MPAs are closely located, 682 the biomass estimations to develop the models came from different reference years 683 which could limit the comparison among MPAs as a result of different environmental 684 conditions (Sala et al., 2012).

685 Despite the limitations, this work provides the basis to assess the role of these 686 Mediterranean coastal areas within a network of MPAs using a food-web modelling 687 approach. These results highlight the capability of the EwE modeling approach to 688 capture protection effects in such small areas despite data limitations. Our results 689 suggest that enforcement can have an impact on the potential benefits of MPAs at 690 the local scale, and a lack of enforcement is noticeable in surrounding areas. MPAs 691 can increase ecosystem maturity and resilience and show potential benefits for 692 small-scale fisheries that act in their surroundings when these areas are well693 enforced. Perceptions of ecological and social benefits are key drivers of stakeholder 694 support to MPAs and could therefore reinforce a virtuous loop further enhancing 
695 MPA effects (Bennett et al., 2019). Future assessments on the spatial distribution of 696 marine resources and the role of these PLs within a network should take place in 697 order to quantify their impacts at a sub-regional (e.g. Northwestern Mediterranean) 698 and regional (e.g. Western Mediterranean) geographic scales.

699

700

701 Acknowledgements

702 This work was funded by EU Research Project SAFENET project ("Sustainable 703 Fisheries in EU Mediterranean Waters through Network of MPAs." Call for proposals 704 MARE/2014/41, Grant Agreement n. 721708). D. Vilas benefited from a Short Term 705 Scientific Mission by the COST Action MarCons (CA15121).

706

707

708

709

710

711

712

713

714

715

716

References

Ainsworth CH, Pitcher TJ. 2006. Modifying Kempton's species diversity index for use with ecosystem simulation models. Ecological Indicators 6: 623-630.

Babcock RC, Shears NT, Alcala AC, Barrett NS, Edgar GJ, Lafferty KD, McClanahan TR, Russ GR. 2010. Decadal trends in marine reserves reveal differential rates of change in direct and indirect effects. Proceedings of the National Academy of Sciences 107: 18256-18261.

Bennett NJ, Di Franco A, Calò A, Nethery E, Niccolini F, Milazzo M, Guidetti P. 2019. Local support for conservation is associated with perceptions of good governance, social impacts, and ecological effectiveness. Conservation Letters: e12640. 
719 Bertrand J, Gil De Sola I, Papaconstantinou C, Relini G, Souplet A. 1997. An

720 international bottom trawl survey in the Mediterranean. The MEDITS

$721 \quad$ Programme: 1-16.

722 Carr MH, Robinson SP, Wahle C, Davis G, Kroll S, Murray S, Schumacker EJ, 723

724

725

726

727

728

729

730

731

732

733

734

735

736

737

738

739

740

741 Williams M. 2017. The central importance of ecological spatial connectivity to effective coastal marine protected areas and to meeting the challenges of climate change in the marine environment. Aquatic Conservation: Marine and Freshwater Ecosystems 27: 6-29.

CBD. 2010. Convention on Biological Diversity, Strategic Plan 2011-2020, Aichi Biodiversity Targets.

Christensen V. 1995. Ecosystem maturity—towards quantification. Ecological modelling 77 : 3-32.

Christensen V. 1996. Managing fisheries involving predator and prey species. Reviews in fish Biology and Fisheries 6: 417-442.

Christensen V, Walters CJ. 2004. Ecopath with Ecosim: methods, capabilities and limitations. Ecological Modelling 172: 109-139.

Christensen V, Walters CJ, Pauly D, Forrest R. 2008. Ecopath with Ecosim version 6: user guide. November 2008. Fisheries Centre, University of British Columbia, Vancouver, Canada 235.

Claudet J. 2013. Unpubl. data. Underwater visual census of Cerbére-Banyuls Marine Protected Area.

Claudet J. 2018. Six conditions under which MPAs might not appear effective (when they are). ICES Journal of Marine Science 75: 1172-1174. 
742 Claudet J, Guidetti P. 2010. Improving assessments of marine protected areas.

$743 \quad$ Aquatic conservation: marine and freshwater ecosystems 20: 239-242.

744 Claudet J, Pelletier D, Jouvenel JY, Bachet F, Galzin R. 2006. Assessing the

745 effects of marine protected area (MPA) on a reef fish assemblage in a

746 northwestern Mediterranean marine reserve: Identifying community-based

747 indicators. Biological Conservation 130: 349-369.

748 Claudet J, Osenberg CW, Benedetti-Cecchi L, Domenici P, Garcia-Charton JA,

749 Perez-Ruzafa A, Badalamenti F, Bayle-Sempere J, Brito A, Bulleri F, et al.

750 2008. Marine reserves: size and age do matter. Ecol Lett 11: 481-489.

751 Claudet J, Osenberg CW, Domenici P, Badalamenti F, Milazzo M, Falcón JM,

752 Bertocci I, Benedetti-Cecchi L, García-Charton J-A, Goñi R, et al. 2010.

$753 \quad$ Marine reserves: Fish life history and ecological traits matter. Ecological

$754 \quad$ Applications 20: 830-839.

755 Coll M, Steenbeek J. 2017. Standardized ecological indicators to assess aquatic

756 food webs: The ECOIND software plug-in for Ecopath with Ecosim models.

$757 \quad$ Environmental Modelling \& Software 89: 120-130.

758 Coll M, Vilas D, Corrales X, Piroddi C, Steenbeek J. 2019. Report describing the

759 quantitative models. Sustainable Fisheries in EU Mediterranean waters

760 through network of MPAs - Safenet MARE/2014/41 Deliverable 4.2.:17

761 Costello MJ, Ballantine B. 2015. Biodiversity conservation should focus on no-take

762 Marine Reserves: 94\% of Marine Protected Areas allow fishing. Trends in

763 ecology \& evolution 30: 507-509. 
764 Costello MJ, Coll M, Danovaro R, Halpin PN, Ojaveer H, Miloslavich P. 2010. A 765 766

767 768

769

770

771

772

773

774

775

776

777

778

779

780

781

782

783

784

785

786

787 analysis of flows. Journal of Theoretical Biology. 
788 Font T, Lloret J. 2011a. Biological implications of recreational shore angling and

789

790

791

792

793

794

795

796

797

798

799

800

801

802

803

804

805

806

807

808

809

810

811 Froese R, Pauly D. 2019. FishBase. France. France. ecosystems 11: 155-188. harvest in a marine reserve: the case of Cape Creus. Aquatic Conservation: Marine and Freshwater Ecosystems 21: 210-217.

Font T, Lloret J. 2011b. Socioeconomic implications of recreational shore angling for the management of coastal resources in a Mediterranean marine protected area. Fisheries Research 108: 214-217.

Font T, Lloret J, Piante C. 2012a. Recreational fishing within marine protected areas in the Mediterranean. MedPAN North Project. WWF France, Paris,

Font T, Lloret J, Piante C. 2012b. Recreational fishing within marine protected areas in the Mediterranean. MedPAN North Project. WWF France, Paris,

Forcada A, Valle C, Bonhomme P, Criquet G, Cadiou G, Lenfant P, SánchezLizaso JL. 2009. Effects of habitat on spillover from marine protected areas to artisanal fisheries. Marine Ecology Progress Series 379: 197-211.

Di Franco A, Plass-Johnson JG, Di Lorenzo M, Meola B, Claudet J, Gaines SD, García-Charton JA, Giakoumi S, Grorud-Colvert K, Hackradt CW. 2018. Linking home ranges to protected area size: The case study of the Mediterranean Sea. Biological Conservation 221: 175-181.

Francour P, Harmelin J-G, Pollard D, Sartoretto S. 2001. A review of marine protected areas in the northwestern Mediterranean region: siting, usage, zonation and management. Aquatic conservation: marine and freshwater 
812 Gabrié C, Lagabrielle E, Bissery C, Crochelet E, Meola B, Webster C, Claudet J, 813 Chassanite A, Marinesque S, Robert P. 2012. The status of marine 814 815 816 817 818 819 820 821

822 823 824 825 826 827 828 829 830 831 protected areas in the mediterranean sea 2012. MedPAN Collection.

García-Rubies A, Zabala i Limousin M. 1990. Effects of total fishing prohibition on the rocky fish assemblages of Medes Islands marine reserve (NW Mediterranean). Scientia Marina, 1990, vol. 54, num. 4, p. 317-328.

Gell FR, Roberts CM. 2003a. Benefits beyond boundaries: the fishery effects of marine reserves. Trends in Ecology \& Evolution 18: 448-455.

Gell FR, Roberts CM. 2003b. Benefits beyond boundaries: the fishery effects of marine reserves. Trends in Ecology \& Evolution 18: 448-455.

Giakoumi S, Scianna C, Plass-Johnson J, Micheli F, Grorud-Colvert K, Thiriet P, Claudet J, Di Carlo G, Di Franco A, Gaines SD. 2017. Ecological effects of full and partial protection in the crowded Mediterranean Sea: a regional meta-analysis. Scientific reports 7: 8940.

Gómez S, Lloret J, Demestre M, Riera V. 2006. The decline of the artisanal fisheries in Mediterranean coastal areas: the case of Cap de Creus (Cape Creus). Coastal Management 34: 217-232.

Goñi R, Badalamenti F, Tupper MH. 2011. Fisheries_Effects of Marine Protected Areas on Local Fisheries: Evidence from Empirical Studies. Marine Protected Areas: A Multidisciplinary Approach 72: 73.

Grüss A, Kaplan DM, Guénette S, Roberts CM, Botsford LW. 2011. Consequences of adult and juvenile movement for marine protected areas. Biological Conservation 144: 692-702. 
835 Guénette S, Pitcher TJ. 1999. An age-structured model showing the benefits of

836

837

838

839

840

841

842

843

844

845

846

847

848

849

850

851

852

853

854

855

856

857

858

marine reserves in controlling overexploitation. Fisheries Research 39: 295303.

Guidetti P, Milazzo M, Bussotti S, Molinari A, Murenu M, Pais A, Spanò N, Balzano $\mathrm{R}$, Agardy T, Boero F, et al. 2008. Italian marine reserve effectiveness:

Does enforcement matter? Biological Conservation 141: 699-709.

Guidetti P, Baiata P, Ballesteros E, Di Franco A, Hereu B, Macpherson E, Micheli

F, Pais A, Panzalis P, Rosenberg AA. 2014. Large-scale assessment of Mediterranean marine protected areas effects on fish assemblages. PLoS One 9: e91841.

Hackradt CW, García-Charton JA, Harmelin-Vivien M, Perez-Ruzafa A, Le Direach L, Bayle-Sempere J, Charbonnel E, Ody D, Reñones O, Sanchez-Jerez P. 2014. Response of rocky reef top predators (Serranidae: Epinephelinae) in and around marine protected areas in the Western Mediterranean Sea. PloS one 9: e98206.

Halpern BS, Frazier M, Potapenko J, Casey KS, Koenig K, Longo C, Lowndes JS, Rockwood RC, Selig ER, Selkoe KA. 2015. Spatial and temporal changes in cumulative human impacts on the world's ocean. Nature communications 6: 7615.

Harmelin-Vivien M, Ledireach L, Baylesempere J, Charbonnel E, Garciacharton J, Ody D, Perezruzafa A, Renones O, Sanchezjerez P, Valle C. 2008. Gradients of abundance and biomass across reserve boundaries in six Mediterranean marine protected areas: Evidence of fish spillover? Biological Conservation 141: 1829-1839. 
859 Hereu Fina B, Quintana Pou X. 2012. El fons marí de les illes Medes i el Montgrí:

860

861

862

863

864

865

866

867

868

869

870

871

872

873

874

875

876

877

878

879 Kaschner K, Rius-Barile J, Kesner-Reyes K, Garilao C, Kullander S, Rees T, 880

Heymans JJ, Coll M, Libralato S, Morissette L, Christensen V. 2014. Global patterns in ecological indicators of marine food webs: a modelling approach. PloS one 9: e95845.

Heymans JJ, Coll M, Link JS, Mackinson S, Steenbeek J, Walters C, Christensen V. 2016. Best practice in Ecopath with Ecosim food-web models for ecosystem-based management. Ecological Modelling 331: 173-184.

Horta e Costa B, Claudet J, Franco G, Erzini K, Caro A, Gonçalves EJ. 2016. A regulation-based classification system for Marine Protected Areas (MPAs). Marine Policy 72: 192-198.

Ivanoff P, Payrot J, Verdoit-Jarraya M. 2010. A recreational fishery survey inside and outside a marine protected area (north-western mediterranean) over one year: typology, seasonal variability and reserve's influence. Mémoire Master. Université Montpellier. 
882 Kellner JB, Tetreault I, Gaines SD, Nisbet RM. 2007. Fishing the line near marine

883

884

885

886

887

888

889

890

891

892

893

894

895

896

897

898

899

900

901

902

903

904

905

reserves in single and multispecies fisheries. Ecological Applications 17:

1039-1054.

Lassalle G, Bourdaud P, Saint-Béat B, Rochette S, Niquil N. 2014. A toolbox to evaluate data reliability for whole-ecosystem models: application on the Bay of Biscay continental shelf food-web model. Ecological modelling 285: 1321.

Lester SE, Halpern BS. 2008. Biological responses in marine no-take reserves versus partially protected areas. Marine Ecology Progress Series 367: 49_ 56.

Lester SE, Halpern BS, Grorud-Colvert K, Lubchenco J, Ruttenberg BI, Gaines SD, Airamé S, Warner RR. 2009. Biological effects within no-take marine reserves: a global synthesis. Marine Ecology Progress Series 384: 33-46.

Libralato S, Coll M, Tempesta M, Santojanni A, Spoto M, Palomera I, Arneri E, Solidoro C. 2010. Food-web traits of protected and exploited areas of the Adriatic Sea. Biological Conservation 143: 2182-2194.

Lizaso JS, Goñi R, Reñones O, Charton JG, Galzin R, Bayle JT, Jerez PS, Ruzafa AP, Ramos AA. 2000. Density dependence in marine protected populations: a review. Environmental conservation 27: 144-158.

Lloret J, Font T. 2013. A comparative analysis between recreational and artisanal fisheries in a Mediterranean coastal area. Fisheries Management and Ecology 20: 148-160.

Lloret J, Planes S. 2003. Condition, feeding and reproductive potential of white seabream Diplodus sargus as indicators of habitat quality and the effect of 
906

907

\section{8}

909

910

911

912

913

914

915

916

917

918

919

920

921

922

923

924

925

926

927

928

929

reserve protection in the northwestern Mediterranean. Marine Ecology Progress Series 248: 197-208.

Lloret J, Zaragoza N, Caballero D, Font T, Casadevall M, Riera V. 2008a. Spearfishing pressure on fish communities in rocky coastal habitats in a Mediterranean marine protected area. Fisheries Research 94: 84-91.

Lloret J, Zaragoza N, Caballero D, Riera V. 2008b. Biological and socioeconomic implications of recreational boat fishing for the management of fishery resources in the marine reserve of Cap de Creus (NW Mediterranean). Fisheries Research 91: 252-259.

Lloret J, Biton-Porsmoguer S, Carreño A, Di Franco A, Sahyoun R, Melia P, Claudet J, Seve C, Ligas A, Belharet M, et al. 2019. Recreational and smallscale fisheries may pose a threat to vulnerable species in coastal and offshore waters of the western Mediterranean. ICES Journal of Marine Science.

Lubchenco J, Grorud-Colvert K. 2015. Making waves: The science and politics of ocean protection. Science 350: 382-383.

Macpherson E, Gordoa A, Garcia-Rubies A. 2002. Biomass size spectra in littoral fishes in protected and unprotected areas in the NW Mediterranean. Estuarine, Coastal and Shelf Science 55: 777-788.

Marshall DJ, Gaines S, Warner R, Barneche DR, Bode M. 2019. Underestimating the benefits of marine protected areas for the replenishment of fished populations. Frontiers in Ecology and the Environment 17: 407-413.

McCauley DJ, Pinsky ML, Palumbi SR, Estes JA, Joyce FH, Warner RR. 2015. Marine defaunation: Animal loss in the global ocean. Science 347: 1255641. 
930

931

932

933

934

935

936

937

938

939

940

941

942

943

944

945

946

947

948

949

950

951

952

953

McClanahan TR, Mangi S. 2000. Spillover of exploitable fishes from a marine park and its effect on the adjacent fishery. Ecological applications 10: 17921805.

Micheli F, Halpern BS, Botsford LW, Warner RR. 2004. Trajectories and correlates of community change in no-take marine reserves. Ecological Applications 14: 1709-1723.

Morissette L. 2007. Complexity, cost and quality of ecosystem models and their impact on resilience: a comparative analysis, with emphasis on marine mammals and the Gulf of St. Lawrence. University of British Columbia.

Murawski SA, Wigley SE, Fogarty MJ, Rago PJ, Mountain DG. 2005. Effort distribution and catch patterns adjacent to temperate MPAs. ICES Journal of Marine Science 62: 1150-1167.

Odum EP, Barrett GW. 1971. Fundamentals of Ecology. Volume 3. Thomson, Brooks/Cole.

Pauly D. 1980. On the interrelationships between natural mortality, growth parameters, and mean environmental temperature in 175 fish stocks. ICES Journal of Marine Science 39: 175-192.

Pauly D, Watson R. 2005. Background and interpretation of the 'Marine Trophic Index'as a measure of biodiversity. Philosophical Transactions of the Royal Society B: Biological Sciences 360: 415-423.

Pelletier D, García-Charton JA, Ferraris J, David G, Thébaud O, Letourneur Y, Claudet J, Amand M, Kulbicki M, Galzin R. 2005. Designing indicators for assessing the effects of marine protected areas on coral reef ecosystems: a multidisciplinary standpoint. Aquatic Living Resources 18: 15-33. 
954 Power ME, Tilman D, Estes JA, Menge BA, Bond WJ, Mills LS, Daily G, Castilla 955 JC, Lubchenco J, Paine RT. 1996. Challenges in the quest for keystones. 956 BioScience 46: 609-620.

957 Prato G, Barrier C, Francour P, Cappanera V, Markantonatou V, Guidetti P, 958 959 960 961 962 963 964 965 966 967 968 969 970 Mangialajo L, Cattaneo-Vietti R, Gascuel D. 2016. Assessing interacting impacts of artisanal and recreational fisheries in a small Marine Protected Area (Portofino, NW Mediterranean Sea). Ecosphere 7: e01601.

Prats L. 2016. Etude de la variabilité spatiale et temporelle dans la Réserve Naturelle Marine de Cerbère-Banyuls et à proximité : caractérisation de la pêche professionnelle, étude de l'effet réserve et des espèces à protéger (Msc thesis). PhD Thesis, Université de Pau et des Pays de L'Adour.

R Core Team. 2017. R: A language and environment for statistical computing [Internet]. Vienna, Austria; 2014.

Roberts C, Hawkins JP. 2000. Fully-protected marine reserves: a guide. WWF Endangered seas campaign Washington, DC.

Roberts CM. 2000. Selecting marine reserve locations: optimality versus opportunism. Bulletin of marine science 66: 581-592.

Roncin N, Alban F, Charbonnel E, Crec'hriou R, de la Cruz Modino R, Culioli J-M, Dimech M, Goñi R, Guala I, Higgins R, et al. 2008. Uses of ecosystem services provided by MPAs: How much do they impact the local economy? 
976

977

978

979

980

981

982

983

984

985

986

987

988

989

990

991

992

993

994

995

996

997

998

Sacanell M. 2012. Study on recreational fishing in the Medes Islands marine protected area. Technical Report to the Medes Islands Marine Reserve Management Authority: $52 \mathrm{pp}$.

Sala E, Ballesteros E, Dendrinos P, Di Franco A, Ferretti F, Foley D, Fraschetti S, Friedlander A, Garrabou J, Guclusoy H, et al. 2012. The structure of Mediterranean rocky reef ecosystems across environmental and human gradients, and conservation implications. PLoS One 7: e32742.

Sala E, Costello C, Dougherty D, Heal G, Kelleher K, Murray JH, Rosenberg AA, Sumaila R. 2013. A general business model for marine reserves. PLoS One 8: e58799.

Sala E, Giakoumi S, Pendleton H editor: L. 2017. No-take marine reserves are the most effective protected areas in the ocean. ICES Journal of Marine Science 75: 1166-1168.

Sala E, Lubchenco J, Grorud-Colvert K, Novelli C, Roberts C, Sumaila UR. 2018. Assessing real progress towards effective ocean protection. Marine Policy 91: 11-13.

Schvartz T, Labbe M. 2012. Suivi à long terme des communautés benthiques des substrats durs dans la Réserve Naturelle Marine de Cerbère-Banyuls.

Sciberras M, Jenkins SR, Mant R, Kaiser MJ, Hawkins SJ, Pullin AS. 2015. Evaluating the relative conservation value of fully and partially protected marine areas. Fish and Fisheries 16: 58-77.

Shannon L, Coll M, Bundy A, Gascuel D, Heymans JJ, Kleisner K, Lynam CP, Piroddi C, Tam J, Travers-Trolet M. 2014. Trophic level-based indicators to 
999

1000

1001

1002

1003

1004

1005

1006

1007

1008

1009

1010

1011

1012

1013

1014

1015

1016

1017

1018

1019

1020

1021

track fishing impacts across marine ecosystems. Marine Ecology Progress Series 512: 115-140.

Soler GA, Edgar GJ, Thomson RJ, Kininmonth S, Campbell SJ, Dawson TP, Barrett NS, Bernard AT, Galván DE, Willis TJ. 2015. Reef fishes at all trophic levels respond positively to effective marine protected areas. PLoS One 10: e0140270.

Steenbeek J. 2018a. MEDITS Data Explorer - Quick Reference Guide. Version 1.5.1, 26 June 2018. Safenet project - EU-DGMARE (MARE/2014/41), Barcelona.

Steenbeek J. 2018b. Diet Calculator - Quick Reference Guide. Version 0.8.5, 11 June 2018. Safenet project - EU-DGMARE (MARE/2014/41), Barcelona.

Stelzenmüller V, Maynou F, Bernard G, Cadiou G, Camilleri M, Crec'hriou R, Criquet G, Dimech M, Esparza O, Higgins R. 2008. Spatial assessment of fishing effort around European marine reserves: implications for successful fisheries management. Marine Pollution Bulletin 56: 2018-2026.

Sumaila UR, Guénette S, Alder J, Chuenpagdee R. 2000. Addressing ecosystem effects of fishing using marine protected areas. ICES Journal of marine Science 57: 752-760.

Tudó P. 2017. Unpubl. Data. Directorate of Fishing and Maritime Affairs, Government of Catalonia, Avinguda Diagonal 523-525, 08029 Barcelona, Spain.

Ulanowicz RE, Puccia CJ. 1990. Mixed trophic impacts in ecosystems. Coenoses: $7-16$. 
1022 Valls A, Gascuel D, Guénette S, Francour P. 2012. Modeling trophic interactions to 1023 assess the effects of a marine protected area: case study in the NW 1024 Mediterranean Sea. Marine Ecology Progress Series 456: 201-214.

1025 Valls A, Coll M, Christensen V. 2015. Keystone species: toward an operational 1026 concept for marine biodiversity conservation. Ecological Monographs 85:

$1027 \quad 29-47$.

1028 Wickham H. 2010. ggplot2: elegant graphics for data analysis. J Stat Softw 35: 65102988.

1030 Zupan M, Bulleri F, Evans J, Fraschetti S, Guidetti P, Garcia-Rubies A, Sostres M, 1031 Asnaghi V, Caro A, Deudero S, et al. 2018a. How good is your marine 1032 protected area at curbing threats? Biological Conservation 221: 237-245.

1033 Zupan M, Fragkopoulou E, Claudet J, Erzini K, Costa BH e, Gonçalves EJ. 2018b. 1034 Marine partially protected areas: drivers of ecological effectiveness.

1035 Frontiers in Ecology and the Environment 16: 381-387.

1036

1037

1038

1039

1040 Tables

1041 Table 1. Surface area $\left(\mathrm{km}^{2}\right)$ and the percentage covered by protection level (PL) and 1042 year of creation of each marine protected area (MPA) (Cerbère-Banyuls, Cap de 1043 Creus and Medes Islands).
MPA
Year of
PL km² (\%) 


\section{1}

2

3

4

5

6

7

8

9

10

11

12

13

14

15

16

17

\begin{tabular}{ccccc} 
& creation & FPA & PPA & UPA \\
\cline { 3 - 5 } Cerbère-Banyuls & 1974 & $0.65(1.59)$ & $5.85(14.32)$ & $35.00(85.68)$ \\
\hline Cap de Creus & 1998 & $0.21(0.69)$ & $7.98(26.11)$ & $22.37(73.20)$ \\
\hline Medes Islands & 1983 & $0.39(2.00)$ & $4.24(21.77)$ & $14.85(76.23)$
\end{tabular}

1044

1045

1046

1047

1048

1049

1050

1051

1052

1053

1054

1055

1056

1057

1058 Figures 


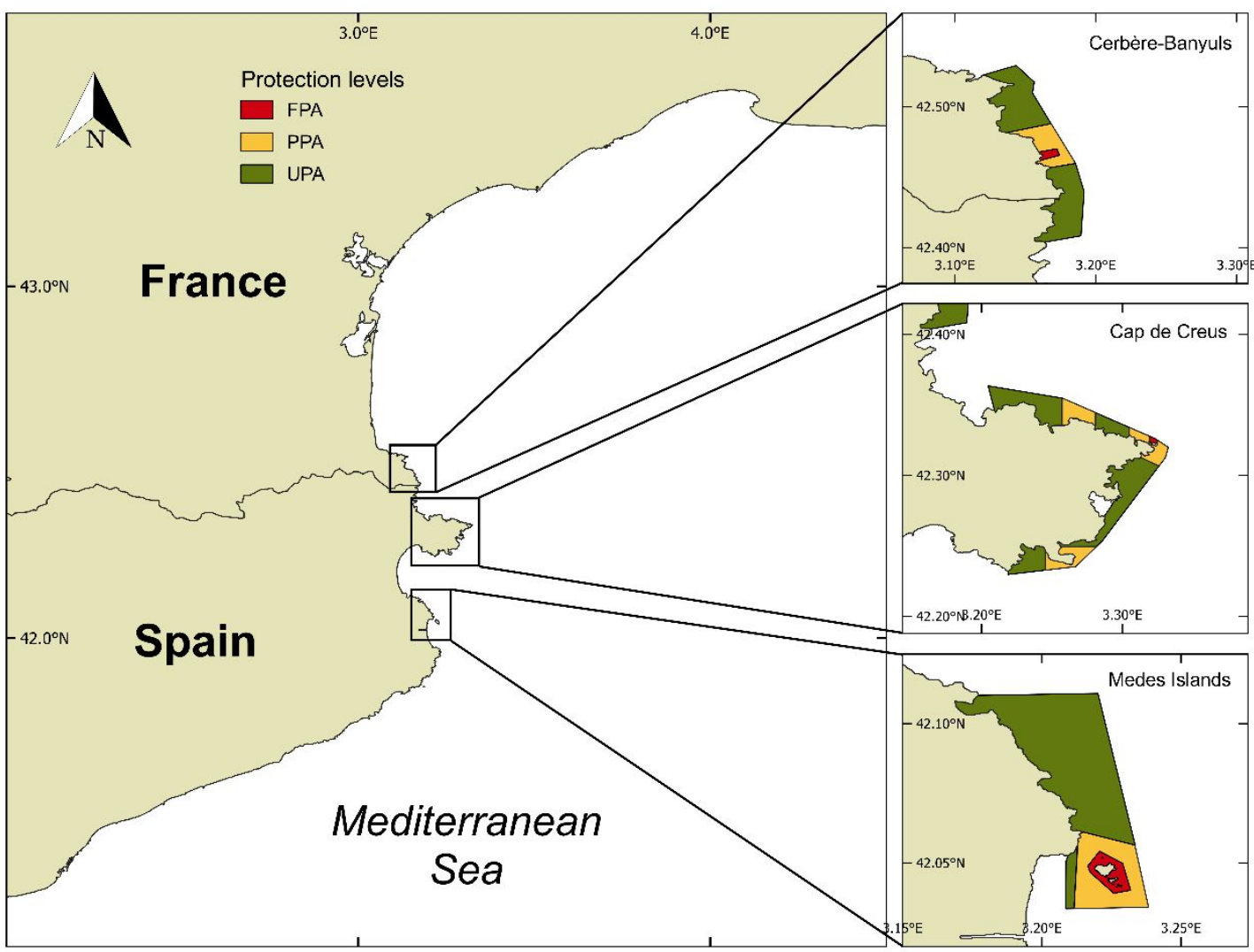

1059

Figure 1. Location of the three MPAs and their protection levels (PL) (FPA: fully 1061 protected area; PPA: partially protected area; UPA: unprotected area) in Cerbère1062 Banyuls, Cap de Creus and Medes Islands.

1063

1064

1065

1066

1067 


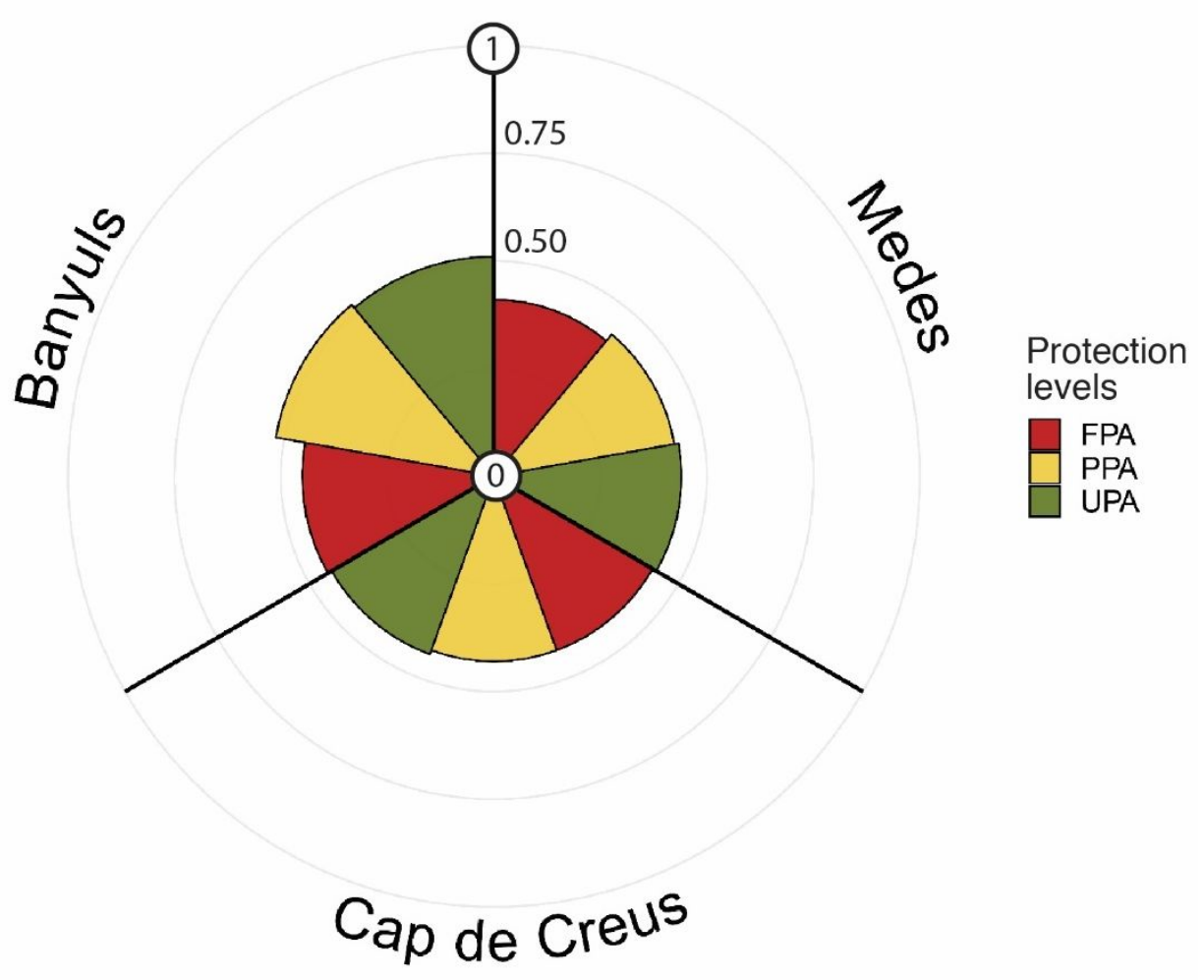

1068

1069 Figure 2. Pedigree index values of the three protection levels $(P L)$ models (FPA: 1070 fully protected area; PPA: partially protected area; UPA: unprotected area) for each 1071 MPA (Cerbère-Banyuls, Cap de Creus and Medes Islands). 
Figure 3. Flow diagrams of three protection levels (PL) (FPA: red; PPA: yellow; UPA: green) of Cerbère-Banyuls MPA model 1085 organized by trophic levels (TL) (y-axis). The size of each circle is proportional to the biomass of the functional group. The 1086 wideness of the connecting lines is proportional to the magnitude of their flows. The numbers identify the functional groups of the PL models (Appendix 1 supplementary material) (Flow diagrams of Cap de Creus and Medes Islands MPA can be 1088 found in supplementary material Figure S6.1.). 

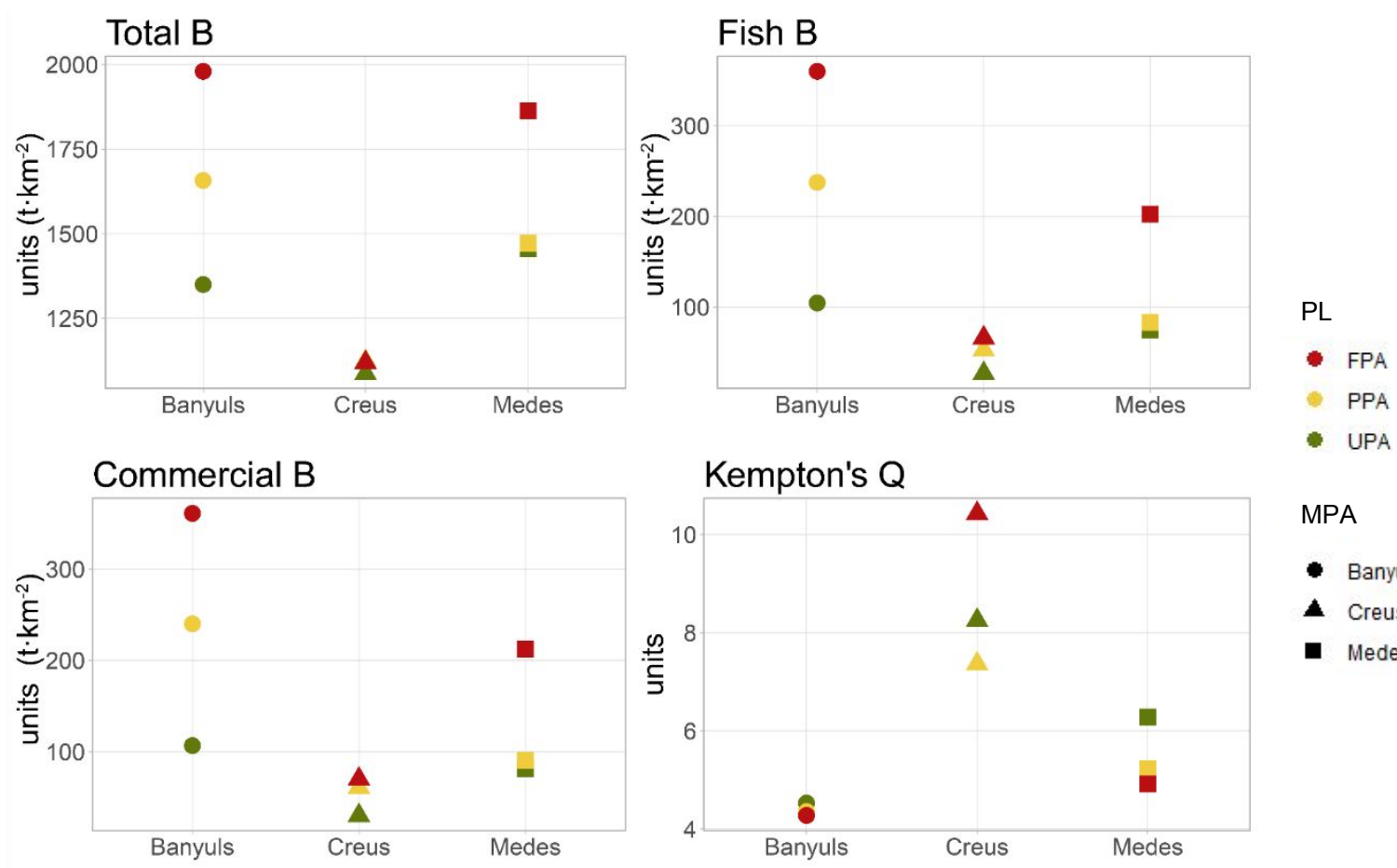

MPA

- Banyuls

- Creus

- Medes

Figure 4. Biomass-based indicators of the three protection levels (PL) (FPA: fully protected area; PPA: partially protected area; UPA: unprotected area) models for each MPA (Cerbère-Banyuls, Cap de Creus and Medes Islands). (B - Biomass, Kempton's Q - Kempton's Q diversity index). 

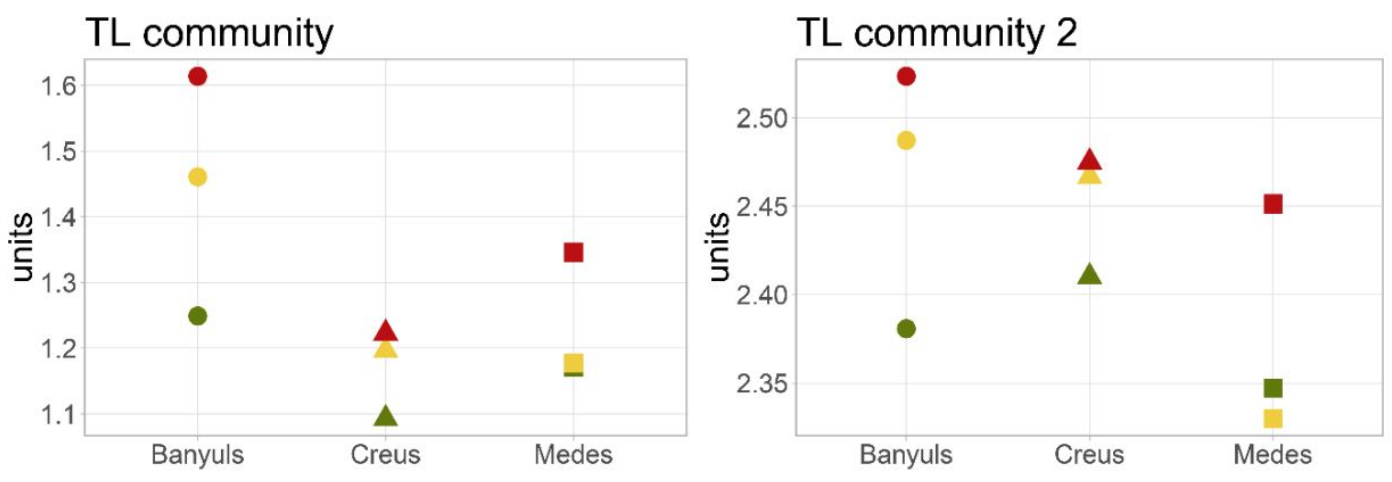

$\mathrm{PL}$

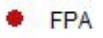

- PPA

- UPA
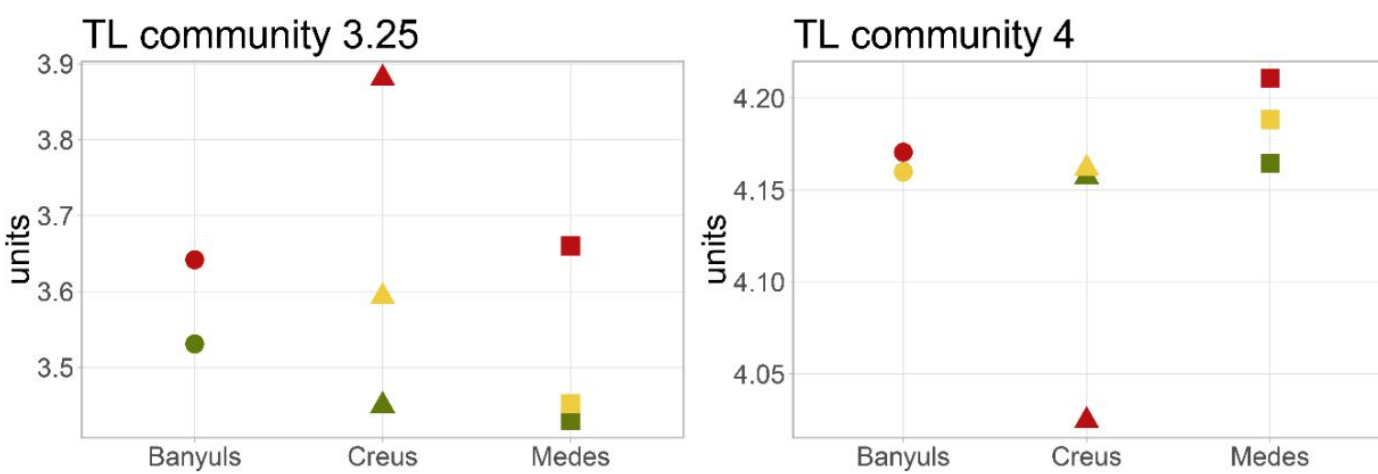

MPA

- Banyuls

- Creus

- Medes

Figure 5. Trophic-based indicators of the three protection levels (PL) (FPA: fully protected area; PPA: partially protected area; UPA: unprotected area) models for each MPA (Cerbère-Banyuls, Cap de Creus and Medes Islands). (TL - trophic level). 

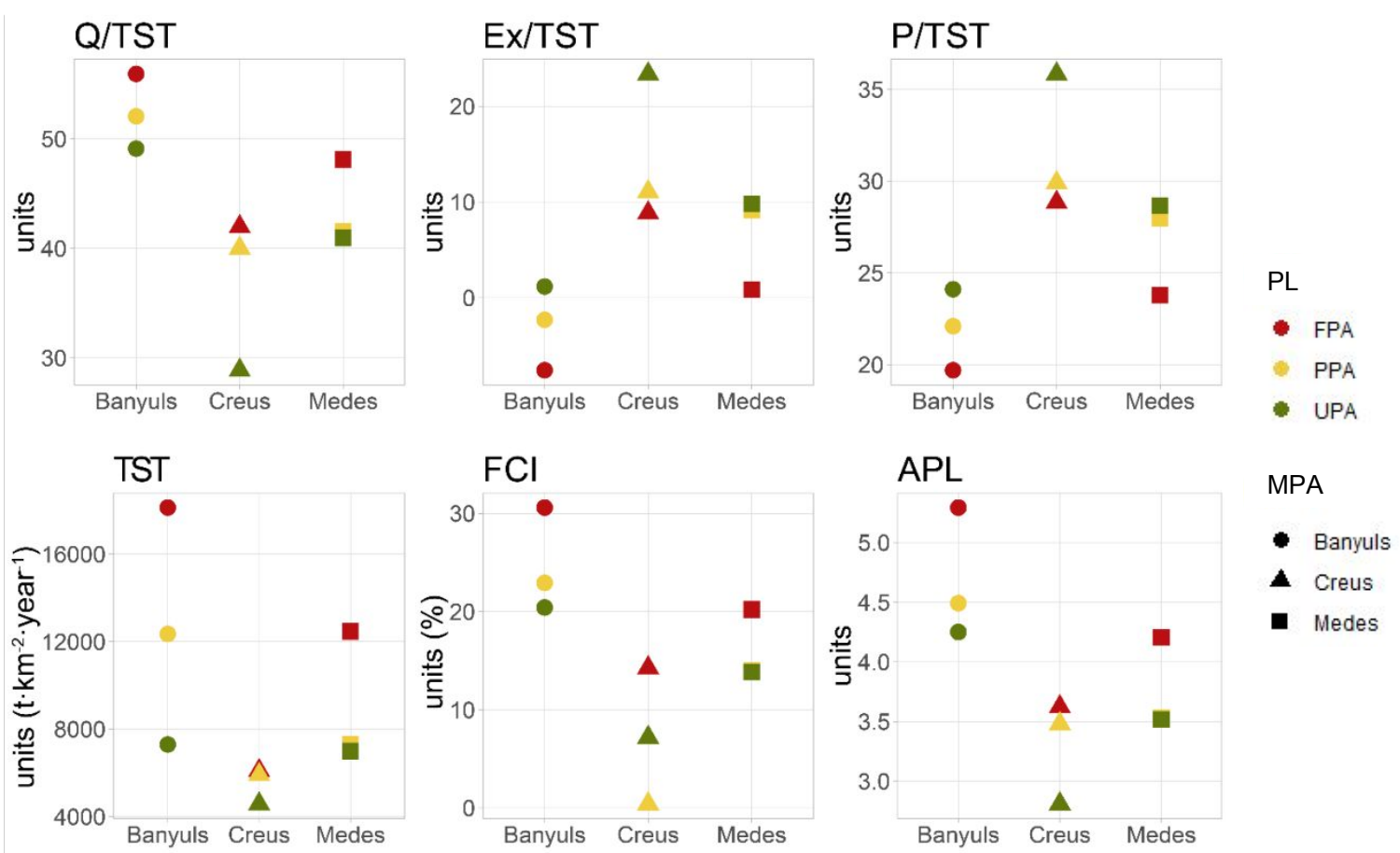

Figure 6. Flow-based indicators of the three protection levels (PL) (FPA: fully protected area; PPA: partially protected area; UPA: unprotected area) models for each MPA (Cerbère-Banyuls, Cap de Creus and Medes Islands). (Q/TST Consumption ratio, Ex/TST - Export ratio, P/TST - Production ratio, TST - Total System Throughtput, FCl - Finn Cycle Index and APL - Average Path Length). 


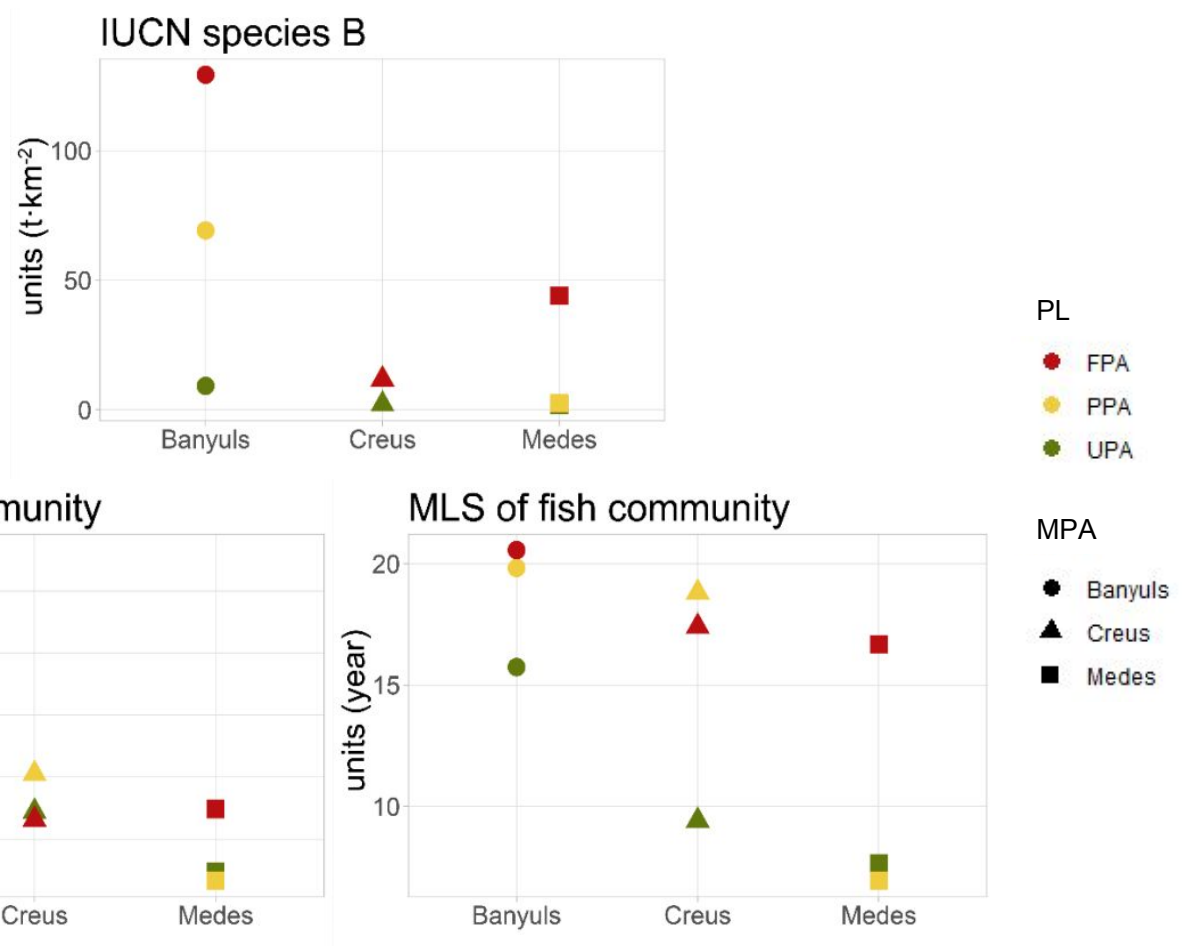

Figure 7. Species-based indicators of the three protection levels (PL) (FPA: fully protected area; PPA: partially protected area; UPA: unprotected area) models for each MPA (Cerbère-Banyuls, Cap de Creus and Medes Islands). (B - Biomass, ML - mean length and MLS - mean life span). 


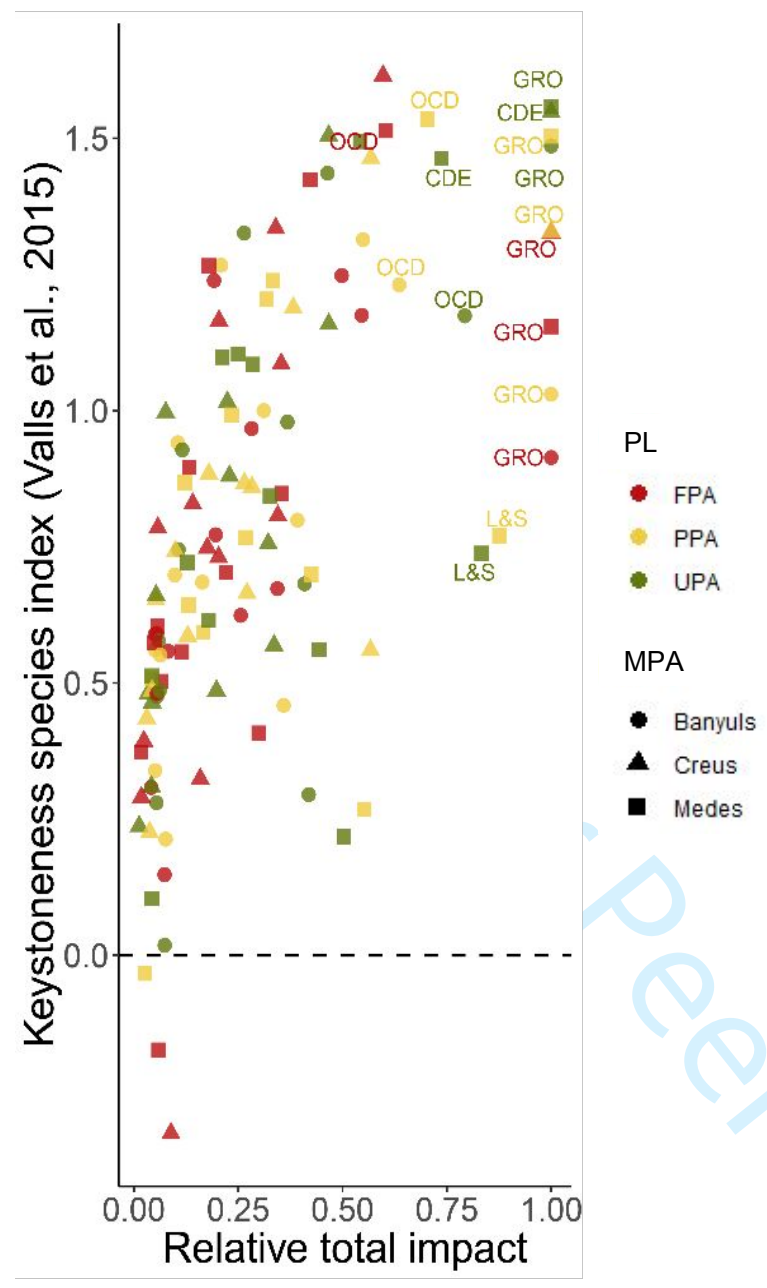

Figure 8. Keystone Index analysis of the three protection levels (PL) (FPA: fully protected area; PPA: partially protected area; UPA: unprotected area) models for each MPA (Cerbère-Banyuls, Cap de Creus and Medes Islands). The acronyms identify the functional group with highest keystoneness index and relative total impact. (GRO - groupers; CDE - common dentex; OCD - Other commercial medium demersal fishes; L\&S - Labridae and Serranidae). 

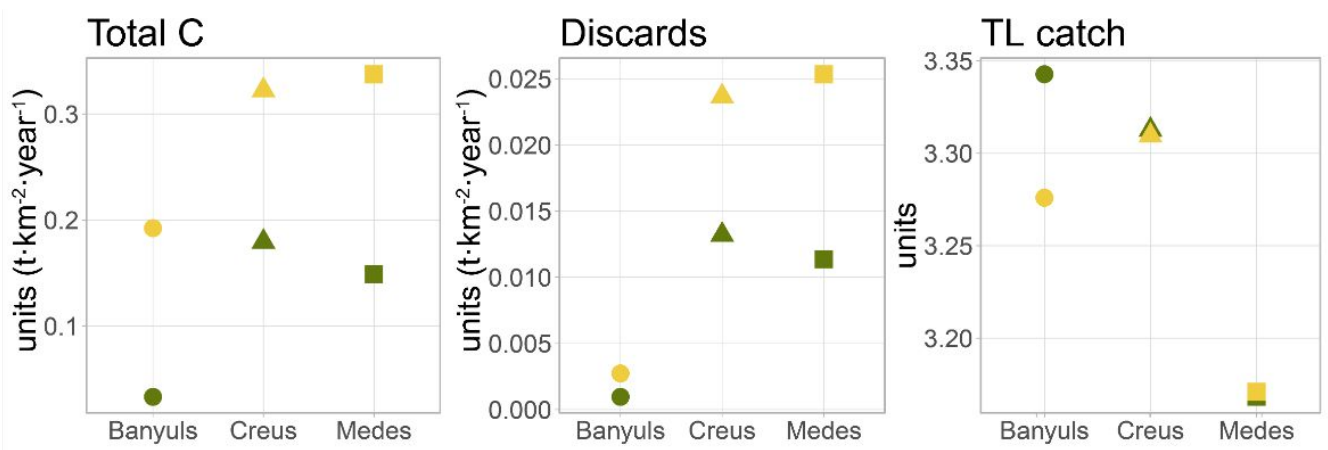

$\mathrm{PL}$
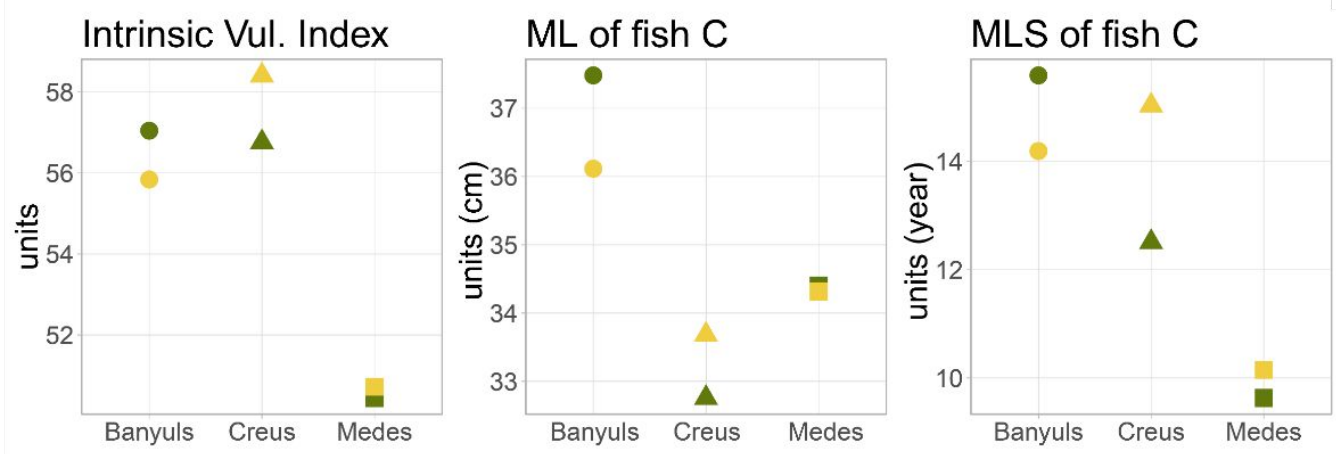

MPA

- Banyuls

- Creus

- Medes

Figure 9. Catch-based indicators of the three protection levels (PL) (PPA: partially protected area; UPA: unprotected area) models for each MPA (Cerbère-Banyuls, Cap de Creus and Medes Islands). (C - Catch; TL - trophic level; ML - mean length; MLS - mean life span). 


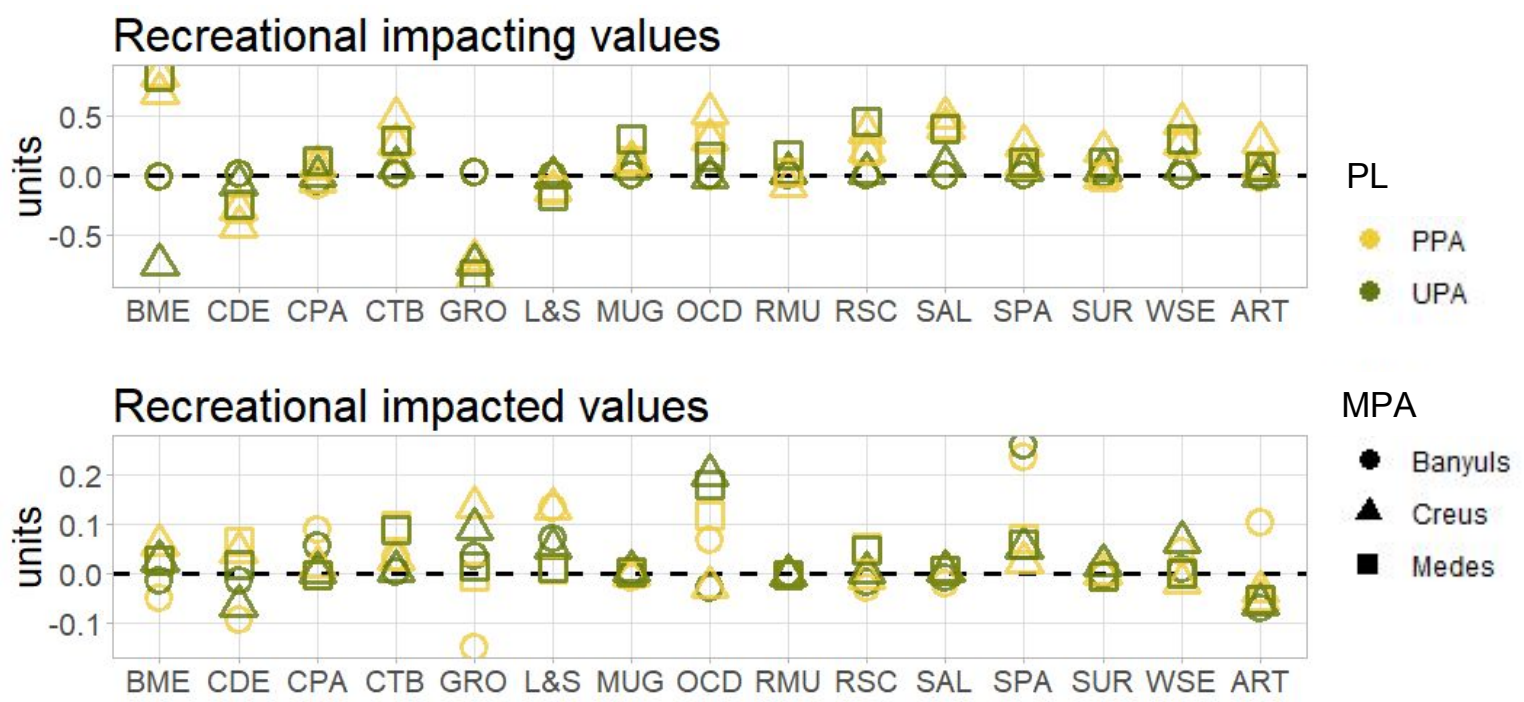

Figure 10. Recreational impacting and impacted values of three protection levels $(P L)$ models (PPA: partially protected area; UPA: unprotected area) for each MPA (Cerbère-Banyuls, Cap de Creus and Medes Islands). (BME - brown meagre; CDE - common dentex; CPA - common pandora; CTB - common two-banded seabream; GRO - groupers; L\&S - Labridae and Serranidae; MUG - Mugilidae; OCD - Other commercial medium demersal fishes; RMU - red mullet; RSC - red scorpionfish; SAL - salema; SPA - Sparidae; SUR - striped red mullet; WSE - white seabream; ART - Small scale fishery). 


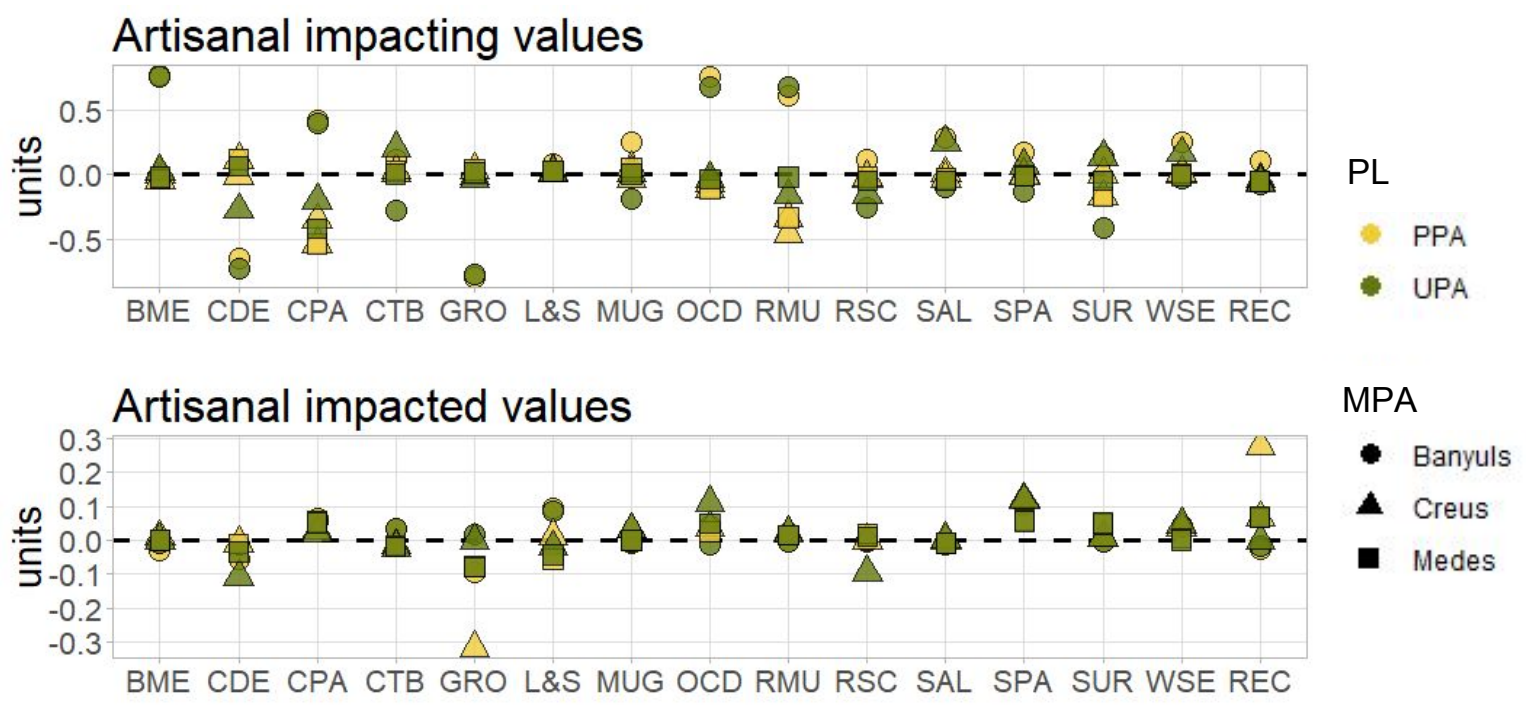

Figure 11. Small scale impacting and impacted values of three protection levels $(P L)$ models (PPA: partially protected area; UPA: unprotected area) for each MPA (Cerbère-Banyuls, Cap de Creus and Medes Islands). (BME - brown meagre; CDE - common dentex; CPA - common pandora; CTB - common two-banded seabream; GRO - groupers; L\&S - Labridae and Serranidae; MUG - Mugilidae; OCD - Other commercial medium demersal fishes; RMU - red mullet; RSC - red scorpionfish; SAL - salema; SPA - Sparidae; SUR - striped red mullet; WSE - white seabream; REC - Recreational fishery). 


\section{Supplementary data}

Additional Supplementary material may be found in the online version of this article:

Appendix 1. Supplementary table: Functional groups included for the protection level models showing those present $(P)$ or absent $(A)$ in each MPA (Table S1.1.).

Appendix 2. Supplementary tables: Cerbère-Banyuls, Cap de Creus and Medes MPAs functional groups species composition and methods and references used to estimate the basic input parameters of the nine Ecopath models (Table S2.1.); Input parameters and outputs estimate for Cerbère-Banyuls (Table S2.2.), Cap de Creus (Table S2.3.) and Medes Islands (Table S2.4.) PL models.

Appendix 3. Supplementary tables: Diet composition matrix for the protection level models of Cerbère-Banyuls (Table S3.1.), Cap de Creus (Table S3.2.) and Medes Islands (Table S3.3.) MPA.

Appendix 4. Supplementary tables: Keystone index and Relative Total Impact values for the functional groups included in Cerbère-Banyuls (Table S4.1), Cap de Creus (Table S4.2) and Medes Islands (Table S4.3) protection level models. FPA: fully protected area; PPA: partially protected area; UPA: unprotected area.

Appendix 5. Additional explanatory text about balancing procedure.

Appendix 6. Supplementary figure: Flow diagrams of three protection levels of Cap de Creus and Medes Islands MPA model (Figure S6.1.). 
1 The effects of marine protected areas on ecosystem recovery and fisheries

2 using a comparative modelling approach

3

4 Authors

5 Daniel Vilas ${ }^{* 1,2,3}$, Marta Coll1,4, Xavier Corrales ${ }^{1,4,5}$, Jeroen Steenbeek ${ }^{4}$, Chiara 6 Piroddi ${ }^{65}$, Antonio Calò ${ }^{76,87}$, Antonio Di Franco ${ }^{76,98}$, Toni Font ${ }^{109}$, Paolo Guidetti ${ }^{76}$, 7 Alessandro Ligas ${ }^{110}$, Josep Lloret ${ }^{109}$, Giulia Prato ${ }^{121}$, Rita Sahyoun ${ }^{132}$, Paolo 8 Sartor $^{110}$ and Joachim Claudet ${ }^{1 \underline{4} 3}$

9 Affiliations

$10{ }^{1}$ Institut de Ciències del Mar (ICM-CSIC), P. Marítim de la Barceloneta, 37-49, 1108003 Barcelona, Spain.

122 Nature Coast Biological Station, Institute of Food and Agricultural Sciences, 13 University of Florida, Cedar Key, FL 32625, United States.

$14{ }^{3}$ Fisheries and Aquatic Sciences Program, School of Forest Resources and 15 Conservation, University of Florida, Gainesville, FL 32611, United States.

$16{ }^{4}$ Ecopath International Initiative (EII), Barcelona, Spain.

$17{ }^{5}$ AZTI, Marine Research, Txatxarramendi Ugartea z/g, E-48395, Sukarrieta, Spain. 18

$19 \quad 65$ European Commission, Joint Research Centre, Institute for Environment and 20 Sustainability, Via Fermi 2749, 21027 Ispra, Italy.

21 ํㅡ Université Côte d'Azur, CNRS, UMR 7035 ECOSEAS, Parc Valrose 28, Avenue 22 Valrose, 06108, Nice, France.

$23 \quad{ }^{87}$ Dipartimento di Scienze della Terra e del Mare (DiSTeM), Università di Palermo, 24 Via Archirafi 20, 90123 Palermo, Italy.

$25 \quad 98$ Stazione zoologica Anton Dohrn, Dipartimento Ecologia Marina Integrata, Sede

26 Interdipartimentale della Sicilia, Lungomare Cristoforo Colombo (complesso

27 Roosevelt), 90142 Palermo, Italy. 
$28 \quad 109$ Universitat de Girona, Girona, Spain.

$29{ }^{110}$ Consorzio per il Centro Interuniversitario di Biologia Marina ed Ecologia

30 Applicata "G.Bacci", viale N. Sauro 4, 57128, Livorno, Italy.Consorzio per il Centro

31 Interuniversitario di Biologia Marina ed Ecologia Applicata "G.Bacci", Italy.

$32 \quad{ }^{12}+$ WWF Italy, Italy.

33132 WWF France, 35-37 rue Baudin - 93310 Le Pré-Saint-Gervais - France.

$34 \quad 1433$ National Center for Scientific Research, PSL Université Paris, CRIOBE, USR

353278 CNRS-EPHE-UPVD, Maison des Océans, 195 rue Saint-Jacques 75005

36 Paris, France.

37

38

39

40

41

42

Abstract

1. The overexploitation of many marine resources and ecosystems calls for the development and implementation of measure-of measures to support their recovery and conservation.

2. We assessed the The potential contributions to support fisheries and ecosystem recovery were assessed at the local level of the three multiple-use Marine Protected Areas (MPAs) of Cerbère-Banyuls, Medes Islands and Cap de Creus, located in the Northwestern Mediterranean Sea.

3. -For each MPA, we developed a food-web model accounting for each

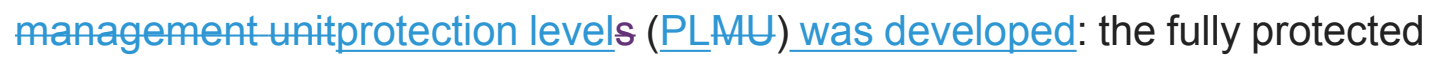
area (FPA), the partially protected area (PPA) and the unprotected area (UPA) surrounding the MPA. Using the resulting nine food-web models, we characterized and compared ${ }_{2}$ the ecosystem structure and functioning of each MUPL were compared and characterized, we assessed differences and 
56

57

58

59

60

61

62

63

64

65

66

67

68

69

70

71

72

73

74

75

76

77

similarities within and among the three MPAs were assessed, and the ecosystem response to fully protection was evaluated for the three MPAs.we evaluated if the ecosystem response to full protection led to specific ecosystem functional traits that are shared among the three MPAs.

4. We showed differences-Differences among MUs in terms of ecosystem structure and functioning were found among PLs. Overall, FPAs presented the most positive effect of protection in terms of ecosystem structure and functioning, followed by PPAs. However, the effects of protection on neighbouring unprotected areas were hardly noticeable.

5. Similarities between Cerbère-Banyuls and Medes Islands MPAs were obtainedobserved, while Cap de Creus MPA showed the least benefits from protection overall. These results are likely due to similarities in the configuration of the protection-protected areas, the levels of enforcement and compliance, and the impact of recreational and small scale fisheries allowed in the PPAs and UPAs.

6. Our This study illustrates that well-enforced Mediterranean MPAs, even when small, can yield local positive impacts on the structure and functioning of marine ecosystems that can contribute to support local fisheries.

Keywords: Management units, Protection levels, fully protected areas, partially protected areas, Ecopath with Ecosim, NW Mediterranean Sea

*Contact author: danielvilasgonzalez@gmail.com 


\section{Introduction}

Marine ecosystems have been degraded at high rates under the cumulative impact of multiple anthropogenic activities (Costello et al., 2010; Halpern et al., 2015)(Costello et al., 2010; Halpern et al., 2015)(Costelloet al., 2010; Halpern et al., 2015). In 2010, the United Nations' Convention on Biological Diversity (CBD) established a target of $10 \%$ of the ocean to be protected by 2020 ("Aichi Target 11") (CBD, 2010)(CBD, 2010)(CBD, 2010). Marine protected areas (MPAs hereafter) are an essential tool for reversing the global degradation of ocean life (Claudet et al., 2008; Babcock et al., 2010; McCauley et al., 2015)(Claudet et al., 2008; Babcock et al., 2010; McCauley et al., 2015)(Babcock et al., 2010; Claudet et al., 2008; McCauley et al., 2015). Several studies have shown that protection from fishing leads to rapid increases in abundance, size and biomass of exploited species and, sometimes, to an increase in species diversity (e.g. Claudet et al., 2010; Di Franco et al., 2018; Lester et al., 2009). However, only $3.7 \%$ of the world's ocean is currently protected with implemented MPAs (Sala et al., 2018)(Sala et al., 2018)(Sala et al., 2018).

MPAs can also provide socio-economic benefits. Economic benefits may stem from the creation of employment opportunities through the development of nonconsumptive activities such as tourism and recreation (Roncin et al., 2008)(Roncin et al., 2008)(Roncin et al., 2008), or from securing future jobs by increasing the chances of managing stocks sustainably (Sumaila et al., 2000)(Sumaila et al., 2000)(Sumaila et al., 2000). Fisheries benefits arise from ecological effects within protected areas in the form of biomass recovery, and subsequent spillover outside the boundaries of the MPA (Di Lorenzo et al., 2016)(Di Lorenzo et al., 2016)(Di Lorenzo et al., 2016) or by increased larval production and supply toward unprotected areas (Marshall et al., 2019)(Marshall et al., 2019)(Marshall et al., 2019), with MPAs finally replenishing external fisheries grounds. Actually, empirical studies comprising small scale (Stelzenmüller et al., 2008)(Stelzenmüller et al., 2008)(Stelzenmüller et al., 2008), recreational (Font et al., 2012a)(Font et al., 2012a)(Font et al., 2012a) and industrial bottom-trawling fishing effort (Murawski et al., 2005)(Murawski et al., 2005)(Murawskiet al., 2005) showed a concentration of fishing activities in the close vicinity of the MPA boundaries. This concentration of 
109 fishing effort, also known as "fishing the line", can reduce the biomass in 110 neighbouring unprotected areas.

111

112

113

114

115

116

117

118

119

120

121

122

123

124

125

126

127

128

129

130

131

132

133

134

135

136

137

138

Most MPAs are multiple-use (Claudet, 2018)(Claudet, 2018)(Claudet, 2018). They combine different levels of protection within a spatially zoned management scheme that can encompass fully protected areas (FPA, also known as no-take areas), where all extractive activities are prohibited, or a type of partially protected areas (PPAs), where some fishing activities are allowed but with varying restrictions (Lubchenco and Grorud-Colvert, 2015; Horta e Costa et al., 2016; Giakoumi et al., 2017)(Lubchenco and Grorud-Colvert, 2015; Horta e Costa et al., 2016; Giakoumi et al., 2017)(Giakoumi et al., 2017; Horta e Costa et al., 2016; Lubchenco and Grorud-Colvert, 2015). Multiple management uses in MPAs can have strong implications in terms of ecosystem and fisheries benefits at the larger scale (i.e. regional). Recent studies showed that ecological benefits can be observed in fully and highly protected areas, while lower levels of protection provide benefits only under specific conditions (i.e. when surrounded by a fully protected area; (Zupan et

al., 2018b)(Zupan et al., 2018b)(Zupan et al., 2018b). In addition, when allowed in a given zone of an MPA, fishing exploitation can become a threat for the overall MPA (Zupan et al., 2018a)(Zupan et al., 2018a)(Zupan et al., 2018a).

While MPAs are an ecosystem-based management tool, it is still unclear how the functioning of ecosystems is affected by protection - in particular, how different levels of protection in multiple-use MPAs translate into ecosystem reorganizations, and how ecosystem response to different levels of protection transfer into fisheries benefits. Here, using food-web modelling techniques, different levels of protection in multiple-use MPA were quantitatively modeled and their ecosystem structural and functional trait responses were compared. Three Mediterranean MPAs were used as case studies to develop ecosystem models for each protection level in each MPA.

_While MPAs are an ecosystem-based management tool, it is still unclear how the functioning of ecosystems is affected by protection - in particular, how different levels of protection in multiple-use MPAs translate into ecosystem reorganizations, and how ecosystem response to different levels or protection transfer into fisheries 
139

140

141

142

143

144

145

146

147

148

149

150

151

152

153

154

155

156

157

158

159

160

161

162

163

164

165

166

167

benefits. Here, using food-web modelling techniques, different levels of protection in multiple-use MPA were quantitatively modeled and their ecosystem structural and functional trait responses were compared. the first attempt to quantitatively model and compare ecosystem structural and functional trait responses to different levels of protection in multiple-use MPAs is presented. Three Mediterranean MPAs were used as a case studies and to develop ecosystem models for each management unit in each MPA.

\section{Material \& Methods}

\section{Study areas}

Different management unitsprotection levels (MUs $\underline{\mathrm{PLs}}$ ) inøf three MPAs inin the North-western Mediterranean Sea were examined: Cerbère-Banyuls MPA in France, Cap de Creus and Medes Islands MPAs in Spain (Figure 1). A^ PL MU-was identified as an area included in an MPA or its surroundings which is classified by its level of protection (fully, partially or unprotected).

These three MPAs were selected because of their similar in bathymetricy ranges, habitat composition, spatial- proximity, and because each MPA combines different levels of protection within a spatially zoned management scheme (Table 1 and Figure 1). Each of the three MPAs has a fully protected area (FPA) at its core, wherewhere fishing exploitation-is not allowed. Neighbouring partially protected areas (PPAs) allow restricted uses such as small-scale (traditional/artisanal) fisheries (Zupan et al., 2018a)(Zupan et al., 2018a)(Zupan et al., 2018a). Last, unprotected areas (UPAs) surround each MPA.

In order to model the functioning of each MPA and the influence of the protected area onte the unprotected area, the FPA, PPA and UPA zones in isolation were modelled. The boundaries of UPAs were selected as all areas adjacent to the MPA with similar ecological characteristics (Figure 1).

\section{Ecosystem modelling approach}

PLAU models were developed using the Ecopath with Ecosim approach (EwE 6.6 version) (Christensen and Walters, 2004; Christensen et al., 2008)(Christensen 
168

169

170

171

172

173

174

175

176

177

178

179

180

181

182

183

184

185

186

187

188

189

190

191

192

193

194

195

and Walters, 2004; Christensen et al., 2008)(Christensen et al., 2008; Christensen and Walters, 2004) and followed the best practices rules (Heymans et al., 2016)(Heymans et al., 2016)(Heymans et al., 2016).

Ecopath is a mass-balanced model based on two main equations. The first master equation describes the energy balance for each functional group in the model, so that:

$$
\text { Consumption }=\text { production }+ \text { respiration }+ \text { unassimilated food } \quad \text { Eq. } 1
$$

The second Ecopath equation is based on the assumption that the production of one functional group is equal to the sum of all predation, non-predatory losses, exports, biomass accumulations, and catches, as expressed by the following equation:

$$
P / B_{i} \cdot B_{i}=P / B_{i} \cdot B_{i} \cdot\left(1-E E_{i}\right)+\sum_{j}(Q / B)_{j i} \cdot B_{i} \cdot D C_{j i}+Y_{i}+N M_{i}+B A_{i} \quad \text { Eq. } 2
$$

where $B_{i}$ is the biomass, $(P / B)_{i}$ is the production rate, $(Q / B)_{i}$ is the consumption rate, $D C_{j i}$ is the fraction of prey $i$ included in the diet of predator $j, N M_{i}$ is the net migration of prey $i, B A_{i}$ is the biomass accumulation of prey $i, Y_{i}$ is the catch of prey $i$, and $E E_{i}$ is the ecotrophic efficiency of prey $i$, that is, the proportion of production used in the system or exported.

\section{Model parametrization}

An ecosystem model was built for each management unitprotection level, i.e. for each combination of the three MPAs and three protection levels (FPA, PPA and UPA). The nine PLAU models were built using the best available information and represented periods from 2000 s to 2010 s, mostly limited by the available biomass data from the underwater visual census (UVC). Specifically, the Cerbère-Banyuls MPA model included most of the data from 2013, while the Cap de Creus MPA and the Medes Islands MPA models included most of their information from the period (2005-2008) and (2000-2004), respectively.

Species presence and their biomass were aggregated in functional groups (FGs) of species or groups of species clustered according to their trophic ecology, 
196 commercial value, and abundance in the ecosystem. The meta-web structure 197 previously defined for the Western Mediterranean Sea model (Coll et al., 2019)(Coll 198 et al. 2019)(Collet al., 2019a) developed under the SafeNet Project ${ }^{1}$ context was 199 followed. This meta-web structure was adapted to local conditions, removing those 200 FGs which did not occur in the study areas. The final food-web structure of Cerbère201 Banyuls MPA contained 64 functional groups (two2 marine mammals, 3-three 202 seabirds, 1 - one sea turtle, 8 - eight pelagic fish, 25 demersal fish, 3 three 203 cephalopods, 14 invertebrates, 2 primary producers, 2 two zooplankton, 2 two 204 phytoplankton and 2 two detritus), while Cap de Creus MPA and Medes Islands MPA 205 had 67 functional groups each (2two marine mammals, 3-three seabirds, 1-one sea 206 turtle, 9-nine pelagic fish, 25 demersal fish, 3-three cephalopods, 14 invertebrates, 4 207 four primary producers, 2 two zooplankton, 2 two phytoplankton twd $_{2}$ two detritus) 208 (supplementary material Table S1.12). Except in the case of FPAs, which do not 209 have discards because all fishing extractions are forbidden, food-web structures of 210 each PLAU in the same MPA were identical.

FGs' biomass were obtained from different sources from the study area or surrounding areas (see additional explanatory text in Appedix 4 and-supplementary

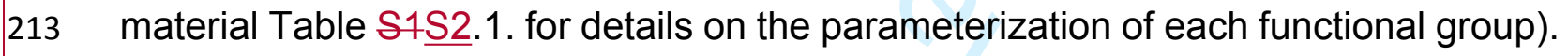
214 The nine PL models share biomass data on some FGs (marine mammals, seabirds, 215 sea turtles, pelagic fish, some invertebrates' groups, primary producers, zooplankton 216 and phytoplankton) for two main reasons: the lack of local data and/or the closeness 217 among these MPAs. The rest of the FGs were parameterized with local information 218 available from field studies for Cerbère-Banyuls (underwater visual census, UVC) 219 The nine PL models share biomass data on some FGs (marine mammals, seabirds, 220 sea turtles, pelagic fish, some invertebrates' groups, primary producers, zooplankton 221 and phytoplankton) for two main reasons: the lack of local data and/or the closeness 222 among these MPAs. The rest of the FGs were parameterized with local information 223 available from field studies for-Cerbère-Banyuls (underwater visual census, UVC) 224 (Claudet, 2013)(Claudet, 2013) and literature for Cap de Creus and Medes Islands

\footnotetext{
${ }^{1}$ http://www.criobe.pf/recherche/safenet/
} 
225 models (García-Rubies and Zabala i Limousin, 1990; Macpherson et al., 2002; 226 Hereu Fina and Quintana Pou, 2012; Hereu Fina et al., 2017)(García-Rubies and 227 Zabala i Limousin, 1990; Macpherson et al., 2002; Hereu Fina and Quintana Pou, 228 2012; Hereu Fina et al., 2017) (supplementary material Table S2.1.) except for some 229 non-reef fish and invertebrates' FG. For these non-reef fish FG (e.g. Aanglerfish), 230 MEDITS trawling survey (Bertrand et al., 1997)(Bertrand et al., 1997) data were 231 extracted with a new released-software insidedeveloped for SafeNet Project, which 232 is called-MEDITS data explorer v. 1.5 .1 (Steenbeek, 2018a)(Steenbeek, 2018a). This 233 tool allowed us to extract MEDITS data easily, and itto scales biomass data to the 234 area and bathymetric rangesautomatically. We extracted-MEDITS trawling survey 235 data were extracted from the closest point to each MPA, in order to have biomass 236 data for those species that were not present during field studies. Those species are 237 present in the MPAs, but they are less important in MPAs in terms of biomass. This 238 assumption was assessed previously withby expert knowledge from the project. For 239 invertebrates' FGs whose biomass estimates were not available, realistic EE values 240 were used to estimate the biomass of four FGs in Cerbère-Banyuls models and six 241 FGs in Cap de Creus and Medes Islands models (supplementary material Table 242 S2.2.). Additionally, scaling factors were used on biomass data of pelagic fish groups 243 available from the MEDITS oceanographic survey, which does not fully cover coastal 244 areas. Thus, this scaling enabled to adapt the estimates and get more accurate 245 biomass values for these coastal areas. The scaling conversions were based on 246 species depth distribution (extracted from Aquamaps - www.aquamaps.org) 247 (Kaschner et al., 2013)(Kaschner et al., 2013) and took into account their 248 contribution in each FG.

250 Production (P/B, year-1) and consumption ( $Q / B$, year ${ }^{-1}$ ) rates were either 251 estimated using empirical equations (Heymans et al., 2016)(Heymans et al., 252 2016)(Heymans et al., 2016), taken from literature or from other models developed 253 in the Mediterranean Sea (Coll et al., 2019)(Coll et al., 2019)(Coll et al., 2019b) 254 (supplementary material Table S1⒉1). Additionally, local body lengths of reef- 
255 associated species obtained from UVC (Di Franco, 2018)(Di Franco, 2018)(Di Franco, 256 2018) were used to estimate $P / B$ and $Q / B$ rates using empirical equations and local 257 data (Pauly, 1980)(Pauly, 1980)(Pauly, 1980).

Diet matrices (supplementary material Appendix 3, Tables S3.1., S3.2. and S3.3.) were built using The-diet information which was compiled using published studies on stomach content analyses, giving preference to local or surrounding areas

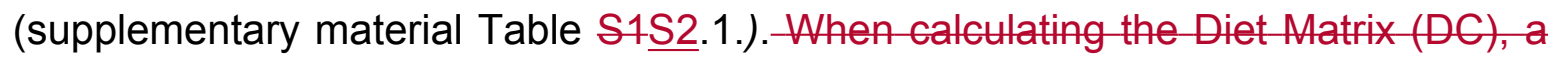
pedigree index associated with each predator FG (supplementary material appendix Z, Table S2.1., S2.2., S2.3.) was generated. We used the-1 (Steenbeek, 2018b)(Steenbeek, 2018b), a custom-build extraction tool, was used (Steenbeek 2018), a custom-built extraction tool that to auto matizes

270 to the small sizes of the MUsPLs investigated and the capacity to-of some species 271 to move between AUsPLs (Gell and Roberts, 2003a; Grüss et al., 2011)(Gell and 272 Roberts, 2003a; Grüss et al., 2011)(Gell and Roberts, 2003a; Grüss et al., 2011), a 273 fraction of the diet composition of these species was set as import for all MUs 274 based on the time that these species feed outside the areas and their ecological 275 traits. This import was based on the size, behaviour, and ecology of species of each 276 functional group (Froese and Pauly, 2019)(Froese and Pauly, 2019)(Froese and Pauly, 2019).

Fisheries data were obtained from different sources (database, literature and 278 unpublished data) (additional explanatory text in Appendix 4 and-supplementary 279 material Table S1 S2.1) and the information on catches was split into two fishing 280 fleets - recreational and professional small scale (except for FPA models where 281 fishing activities are not allowed). Regarding professional small scale fisheries 282 catches, Cerbère-Banyuls data were obtained from a local study Regarding 283 professional small scale fisheries catches, Cerbère-Banyuls data were obtained from 284 a local study (Prats, 2016)(Prats, 2016), while for Cap de Creus and Medes Islands 
285 the data came from an official dataset of the regional government of Catalonia 286 managed by the Institute of Marine Sciences (ICM-CSIC), while for Cap de Creus 287 and Medes Islands the data came from an official dataset of the regional government 288 of Catalonia managed by the Institute of Marine Sciences (ICM-CSIC) (Tudó, 289 2017)(Tudó, 2017). For Cap de Creus, these landings were from Llançà, Port de la 290 Selva, Cadaqués and Roses harbours, where the main fleets operating are located, 291 and were scaled by the months of fishing activity of the fleets inside the MPA For 292 Gap-de Creus, these landings were from Llançà, Port de la Selva, Cadaqués and 293 Roses harbours, where the main fleets operating are located, and were scaled by 294 the months of fishing activity of the fleets inside the MPA (Gómez et al., 295 2006)(Gómez et al., 2006). For recreational fisheries, we extracted-catches were 296 extracted from Ivanoff et al. (2010)(2010) in Cerbére-Banyuls. Cap de Creus 297 recreational catches came from Font and Lloret (2011a, 2011b)(2011a, 2011b) and 298 Lloret et al. (2008a, 2008b) (2008a, 2008b). Whereas, for Medes, recreational catches 299 were extracted from Sacanell (2012)(2012).

300

301

Ensuring mass-balance and assessing the quality of the models

302

In an Ecopath model, the energy input and output of all functional groups must 303 be balanced under ecological and thermodynamic rules: (1) EE < 1.0; (2) P/Q 304 [production/consumption rate or gross efficiency (GE)] should range from 0.1 to 0.3 305 with the exception of fast fast-growing groups such as bacteria; (3) R/A 306 (respiration/food assimilation) < 1; (4) R/B (respiration/biomass) should range from 3071 to 10 for fish and higher values for small organisms; (5) NE (net efficiency of food 308 conversion) > GE and (6) P/R (production/respiration) < 1 (Christensen et al., 2008; 309 Heymans et al., 2016)(Christensen et al., 2008; Heymans et al., 2016)(Christensen 310 et al., 2008; Heymans et al., 2016). A standardized procedure to ensure the mass311 balance of all the models was followed (detailed information can be found at 312 Appendix $4 \underline{5}$ in the supplementary material).

313 The quality of the models was evaluated using the pedigree routine, which 314 allows assigning a pedigree value for each input parameter $(B, P / B, Q / B$, diet and 
315 catches) (Christensen and Walters, 2004; Christensen et al., 2008)(Christensen and 316 Walters, 2004; Christensen et al., 2008)(Christensen et al., 2008; Christensen and 317 Walters, 2004). All pedigree values were established manually except for diet 318 pedigree values, which were obtained from the Diet Calculator software (Steenbeek, 319 2018b)(Steenbeek, 2018b)(Steenbeek, 2018). This software computes a total pedigree 320 value for each diet record, which is a weighted average of four field scores from four 321 diet features (region, year, type of data and method). Pedigree values were first used 322 to determine which parameters were of lower quality and thus could be modified 323 during the balancing procedure. Afterwards, they were used to calculate the 324 pedigree index of each model, which vary between 0 (lowest quality) and 1 (highest 325 quality) (Christensen and Walters, 2004)(Christensen and Walters, 2004)(Christensen and 326 Walters, 2004).

\section{Models analyses and ecological indicators}

328 Flow diagram

The food-web structure of each PLMU in the three MPAs was visualized using a flow diagram. Flow diagrams were obtained using the ggplot2 package (Wickham, 331 2010)(Wickham, 2010)(Wickham, 2010) implemented in $R$ software ( $R$ Core Team, 332 2017)(R Core Team, 2017)(R Core Team, 2017) and were built from the biomass, and trophic 333 levels (TL, as outputs) of each FG, and the direct trophic interactions among them 334 extracted from EwE. The TL identifies the position of organisms within food webs by 335 tracking the source of energy for each organism, and it is calculated by assigning 336 primary producers and detritus a TL of 1 (e.g. phytoplankton), and consumers to a 337 TL of 1, plus the average TL of their prey weighted by their proportion in weight in 338 the predator's diet (Christensen, 1996)(Christensen, 1996)(Christensen, 1996).

\section{Ecological indicators}

340 Several ecological indicators were computed toTo describe the state and 341 functioning of the ecosystems, several ecological indicators were computedderived 342 from modeling procedure. A detailed explanation of the equations to calculate these 343 indicators are described in Christensen et al. (2008)(2008) and Coll and Steenbeek 
344 (2017). These indicators were_-divided into five main groups following: Goll-and 345 Steenbeek, (2017):

- Biomass-based. These indicators are calculated from the biomass of 
374 threatened (ES, $t \cdot \mathrm{km}^{-2}$.year $\left.{ }^{-1}\right)$, mean length (ML) of fish in the community ( $\mathrm{ALL}$, $375 \mathrm{~cm}$ ) and mean life span (MLS) of fish in the community (MLS, year).

$376 \quad$ - Flow-based. Several indicators are related to total flowsrelated to the 377 interactions in the network of the system and six were usedselected. The 378 Total System Throughput (TST, $\left.\mathrm{t}^{\mathrm{km}} \mathrm{km}^{-2} \cdot \mathrm{year}^{-1}\right)$ is ; the sum of all flows in the 379 model (consumption, export, respiration, and flow to detritus), and -it is considered an overall measure of the "ecological size" of the system (Finn, 1976)(Finn, 1976)(Finn, 1976). The Finn's Cycling Index (FCl, \%) is the fraction of the ecosystem's throughput that is recycled (Finn, 1976)(Finn, 1976)(Finn, 1976)., and the higher its value ...... The Average Path Length (APL) is defined as the average number of groups that flows passes through and $X X X X X$ is an indicator of stress (Christensen, 1995)(Christensen, 1995)(Christensen, 1995). Therefore, the higher $\mathrm{FCl}$ and $\mathrm{APL}$ values are, the more resilient, stable and mature the ecosystem is (Christensen, 1995)(Christensen, 1995). - Additional indicators were selected because of their information on the distribution of ecosystem flows and their robustness in front of models' comparison (Heymans et al., 2014)(Heymans et al., 2014)(Heymans etal., 2014) and their information on the distribution of ecosystem flows: the ratios of consumption $(Q)$, export $(E x)$ and production $(P)_{\bar{\Sigma}}$.

- Catch-based. These indicators are based-focused on catch and discard species datathe fishing activity and based on catch and discard data. They can give an idea of $n$ the potential effect on adjacent fisheries through spillover of exploited fishes from FPAs (McClanahan and Mangi, 2000)(McClanahan and Mangi, 2000)(AcClanahan and Mangi, 2000), so greater catch-based indicators values are expected on well-enforced MPAs. -Also, PPAs is usuallyare surrounding FPAs and is where higher fishing pressure levels occur (Stelzenmüller et al., 2008)(Stelzenmülller et al., 2008), so catch-based indicators are supposed to be higher in these areas. Six indicators were included: total catch ( $\mathrm{TC} \cdot \mathrm{km}^{-2}$ year ${ }^{-1}$ ), total discarded catch (TD, $\mathrm{t} \cdot \mathrm{km}^{-2}$.year $\left.{ }^{1}\right)$, trophic level $\underline{T L}$ of the catch,$(T L C)$, the intrinsic vulnerability index of catch 
404

405

406

407

408

409

410

411

412

413

414

415

416

417

418

419

420

421

422

423

424

425

426

427

428

429

430

431

432

433

$(\mathrm{V})$, mean length $\underline{\mathrm{ML}}$ of fish in the catch (MLG, $\mathrm{cm})$ and mean life spanMLS of fish in the catch (MLC, year).

Additionally, the mixed trophic impact (MTI) analysis was performed to quantify direct and indirect trophic interactions among functional groups (Ulanowicz and Puccia, 1990)(Ulanowicz and Puccia, 1990)(Ulanowicz and Puccia, 1990). This analysis quantifies the direct and indirect impacts that a hypothetical increase in the biomass of one functional group would have on the biomass of all the other functional groups, including the fishing fleets. The MTI for living groups is calculated by constructing an $\mathrm{n} \times \mathrm{n}$ matrix, and quantifying each interaction between the impacting group (j) and the impacted group (i) is:

$M T I_{j i}=D C_{j i}-F C_{i j}$

Eq. 3

where $D C_{j i}$ is the diet composition term expressing how much $i$ contributes to the diet of $j$, and $F C_{i j}$ is a host composition term giving the proportion of the predation on $j$ that is due to $i$ as a predator.

Furthermore, keystoneness analysis was performed for the nine management unitsprotection levels. A keystone species is a species that shows relatively low biomass but has a relatively important role in the ecosystem (Power et al., 1996)(Power et al., 1996)(Poweretal., 1996). To identify the keystone species within the ecosystem, the keystoneness index (KS) of the most important reef FG (common pandora: Pagellus erythrinus; Sparidae; white seabream: Diplodus sargus; common two-banded seabream: Diplodus vulgaris; Common dentex: Dentex dentex; red scorpionfish: Scorpaena scrofa; groupers: Epinephelus spp; brown meagre: Sciaena umbra; Labridae and Serranidae; Other commercial medium demersal fish; salema: Salpa salpa; Mugilidae; red mullet: Mullus barbatus; and striped red mullet: Mullus surmuletus) were estimated using 3 three different methods: (1) Power keystone indicator (Power et al., 1996) (KS ) and (2) Libralato's keystone indicator (Libralato et al., 2006) $\left(\mathrm{KS}_{\llcorner}\right)$, which are based on a measure of trophic impact derived from the MTI analysis, and a quantitative measure of biomass; and (3)_Valls et al. (2015)(2015)(2015) (KSV) keystoneness index, in which the biomass component is based on a descending ranking. These indices are calculated as: 
$\begin{array}{llr}434 & K S_{P i}=\varepsilon_{i \frac{p_{i}}{2}} & \text { Eq.4 } \\ 435 & K S_{L i}=\log \left[\varepsilon_{i}\left(1-p_{i}\right)\right] & \text { Eq.5 } \\ 436 & K S_{V i}=\log \left[I C_{i} \cdot B C_{i}\right] & \text { Eq. } \\ 437 & & \underline{36}\end{array}$

438 where $\varepsilon_{i}$ represents the RTI; $p_{i}$ is the contribution of the group $i$ to the total biomass 439 in the food-web; $I C_{i}$ is a component estimating the trophic impact of the group $i$; and $440 B C_{\mathrm{i}}$ is a component estimating the biomass of the group $i$.

441 Evaluating MPAs and the role of MUsPLs

In order to determine the role of MUsPLs in the functioning of the MPAs, 443 results from ecological indicators (except catch-based indicators) and keystoneness 444 were compared among the three AUSPLs within each MPA. This comparison among 445 MUsPLs ecological indicators served to capture shifts in ecosystem structure and 446 functioning due to the level of protection (Dale and Fortin, 2014)(Dale and Fortin, 447 2014)(Fortin and Dale, 2005).

The sSame above-mentioned indicators were used to evaluate differences among the three studied MPAs, comparing the same AUsPLs of the different MPAs. For instance, considering the FPAs of the three MPAs allowed us to capture how different are these MPAs since-even although they officially offer the same levels of

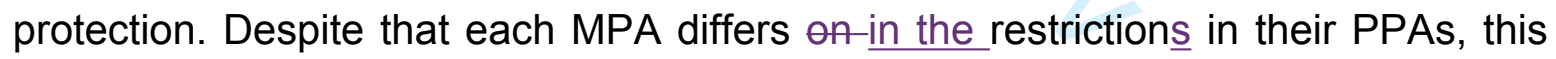
multiple comparison procedure was developed for the three MUsPLs because the ecological theory establishes that reserve effects should extend from FPA beyond its boundaries as a result of the-spillover (Gell and Roberts, 2003b)(Gell and Roberts, z003b)(Gell and Roberts, 2003b).

\section{Impact of small-scale fisheries}

To evaluate the impact of small-scale fisheries on the MPAs, catch-based 459 indicators were examined between PPAs and UPAs of the three MPAs. The mixed 460 trophic impact results of recreational and professional small scale fishing fleets were 461 examined to quantify the direct and indirect impact of each fleet on the functional 
462 groups for PPAs and UPAs of the three studied MPAs, and their potential competition 463 and trade-offs between them were identified.

464

465

466

467 468

469

470

471

472

473

474

475

476

477

478

479

480

481

482

483

484

485

486

487

488

489

490

\section{Results}

The pedigree index values of the PLAHU models showed similar values among them (Figure 2), ranging from 0.41 to 0.52 . The highest pedigree values were obtained for Cerbère-Banyuls, and FPAs obtained-had slightly lower pedigree indexes than the other MUsPLs.

The flow diagrams displayed high levels of biomass even for some high trophic level groups, especially in the FPAs (Figure 3 and supplementary material Figure S5S6.1). Also, the results emphasized-highlighted the complexity of these food webs regarding with respect to the number of trophic links among functional groups with important fluxes of energy from phytoplankton (FG 61 and 62) and detritus (FG 63) up to-the food web.

\section{Ecosystem structure and functional traits}

Overall, biomass-based indicators displayed the same pattern between MUSPLs (Figure 4), with the highest biomass values found in Cerbère-Banyuls, then Medes Islands and finally Cap de Creus. Conversely, the Kempton's b Biodiversity Indicator index (KI) decreased from Cap de Creus to Medes Islands and then Cerbère-Banyuls. Within MUsPLs, the FPAs showed the highest values in terms of total and fish biomass, and they were followed by the PPA in all MPAs. In Cap de Creus similar values were observed among MUS $\underline{P L S}$ for both indicatorstotal, fish and commercial biomass. Kempton's biodiversity index values were similar among PLs for Cerbère-Banyuls, while the highest value was obtained by the UPA for Medes Islands and the FPA for Cap de Creus.

Trophic-based indicators revealed that the TL of the community and TL2 was higher for Cerbère-Banyuls, followed by Medes Islands, while Cap de Creus showed the lowest levels (Figure 5). Cerbère-Banyuls and Medes Islands displayed similar values for TL3.25 and TL4, while Cap de Creus obtained-showed higher variance among these indicators. Specifically, Cap de Creus showed the highest TL3.25 
491 values and the lowest TL4 value. Within AUsPLs, most trophic-based indicators 492 showed the highest values for FPAs followed by PPAs and UPAs. However, the FPA 493 in Cap de Creus displayed the lowest value of TL4 (Figure 5).

Flow-based indicators showed differences between MPAs. Cerbère-Banyuls showed the highest values for Q/TST, TST, $\mathrm{FCl}_{2}$ and $\mathrm{APL}$, while the lowest values for Ex/TST and P/TST (Figure 6). Inversely In contrast, Cap de Creus showed the 497 lowest values for Q/TST, whilst the highest values were observed for Ex/TST and 498 P/TST. Medes Islands MPA values were located between these two MPAs. 499 Considering PLAU values, flow-based results revealed higher values for FPAs 500 followed by PPAs in most of the flow-based indicators. As an exception, Ex/TST and 501 P/TST were higher for UPAs and lower for FPAs.

502 Results from species and size-based indicators (Figure 7) pointed 503 eutrevealed that Cerbère-Banyuls had the highest values for IUCN species 504 Bbiomass, followed by Medes Islands. Regarding ML and MLS of fish, the highest 505 values were also obtained for Cerbère-Banyuls, followed by Cap de Creus and then 506 Medes Islands. Species and size-based indicators were higher for FPAs, except in 507 Cap de Creus, where PPA had higher values of ML and MLS than FPA.

All keystoneness indices The keystoneness index (Figure 8; Supplementary 509 material appendix Appendix 34) for the nine models identified the same groups-as 510 keystone functional groupss: groupers, o511 common dentex and Labridae \& Serranidae. Particularly, groupers obtained had the 512 highest relative total impact. These results confirmed that groupers play an important 513 ecological role in Mediterranean coastal ecosystems. The kKeystoneness indexices 514 showed different patterns among MUsPLs and MPAs. Medes Islands models 515 ebtained-had the highest number of keystone species followed by Cerbère-Banyuls 516 (Figure 8).

\section{Role and impact of small-scale and recreational fisheries}

$518 \quad$ Total catch and discards showed similar values between Cap de Creus and 519 Medes Islands, while Cerbère-Banyuls presented the lowest values (Figure 9). $\mathbb{Z}$ 520 Vulnerability index values were similar for Cap de Creus and Cerbère-Banyuls, and 
521 with the lowest $\mathbb{V}$ valuesvalue were-found for Medes Islands. FLC $\mathrm{TL}$ of the catch 522 was higher for Cerbère-Banyuls and Cap de Creus and lower for Medes Islands 523 (Figure 9), and these results are in line with MLSG-MLS of the catch results (Figure 524 7). Also, Cerbère-Banyuls showed the highest value for MLc while Cap de Creus got 525 had the lowest onevalue. TC and discards exhibited higher values for PPAs than 526 UPAs. IV indexes were higher for PPAs than UPAs except for Cerbère-Banyuls. TLG 527 The catch TL values were similar between PPA and UPA in Cap de Creus and 528 Medes Islands, while it was higher for PPA in Cerbère-Banyuls. ML and MLS of the 529 catch results evidenced-showed similar values between MUs $\underline{P L s}$ for Medes Islands, 530 while PPA obtained-showed higher values in Cap de Creus and lower in Cerbère531 Banyuls.

The MTI analysis based on the recreational fisheries (Figure 10) revealed that 533 their impacts on the FGs in the ecosystem were clearly higher than the impacts of 534 FGs to on recreational fisheries (between - 0.86 and 0.84 and -0.15 and 0.26 , 535 respectively). The highest impacting and impacted values were found for PPA in Cap 536 de Creus, where impacted values were higher for PPA in Cerbère-Banyuls 537 (positively on Sparidae and negatively on brown meagre, common dentex and 538 groupers) and Medes Islands (positively on common two-banded seabream and red 539 scorpionfish). Impacts on recreational fisheries were low (close to zero) for most 540 groups except for groupers and Sparidae in Cerbère-Banyuls.

541 In line with impacts of recreational fisheries, impacts of small scale fisheries 542 (Figure 11) were higher and more fluctuating than impacts of FGs to small scale 543 fisheries (ranging from -0.80 to 0.77 and -0.32 to 0.12 , respectively). Generally, small 544 scale impact results did not evidence show great differences between MUsPLs. The 545 highest small scale fisheries impacting values were obtained in Cerbère-Banyuls, 546 with some exceptions for negative impacting values of some groups (common 547 pandora and red mullet in Cap de Creus). Small scale fisheries impacted results 548 displayed low values (close to zero), except for groupers, which highly negatively 549 impacted on the small scale fishery of PPA in Cap de Creus. 
550

551

552

553

554

555

556

557

558

559

560

561

562

563

564

565

566

567

568

569

570

571

572

573

574

575

576

577

578

579

Overall, the MTI analysis based on fisheries did not show any pattern among MUsPLs and MPAs, and fisheries impacting values were clearly higher and more fluctuating than impacted values-(ranging from -0.86 to 0.84 and -0.32 to 0.26 , respectively). Mostly, the highests impacts of recreational fisheries were found-for the PPA of Cap de Creus, while the highests impacts of smale scale fleet were found for Cerbère-Banyulsimpacts of recreational fisheries were higher for the PPA of Cap de Creus, while impacts of small scale fleet were higher for Cerbère-Banyuls. Specifically, MTI analysis revealed that the impacts of recreational fisheries were greater (positively and negatively) for brown meagre and groupers. On the other hand, the recreational fishery was highly (positively) impacted by other commercial medium demersal fish and Sparidae (Figure 10). Regarding small scale fishery, brown meagre, other commercial medium demersal fish and red mullet were positively impacted by recreational fisheries, while common dentex and groupers were negative impacted (Figure 11). Groupers was the most impacting (negatively) group on the small scale fishery. Recreational and small scale fisheries showed low impacted and impacting values between them. Among them, the highest impact was for the recreational fleet on the small scale one in the PPA of Cap de Creus $(0.28)$.

\section{Discussion}

Nine quantitative models were built to investigate the differences among MUsPLs of three MPAs in the NW Mediterranean Sea. This analysis allowed us to assess the impact of protection on the ecosystem at local scale. TFo our knowledge, this is the first attempt to develop a food-web model for each MUsPLs within MPAs to assess the impact of protection on the ecosystem at local scale.

The input data were qualitatively acceptable if our results are compared to the distribution of pedigree values in other existing models (Morissette, 2007; Lassalle et al., 2014)(Morissette, 2007; Lassalle et al., 2014)(Lassalle et al., 2014; Morissette, 2007). Also, the pedigree values of the models were comparable to that from other available MPA models in the Western Mediterranean Sea, such as 0.49 in the Portofino MPA (Prato et al., 2016)(Prato et al., 2016)(Prato et al., 2016a). However, FPAs showed the lowest pedigree values because several P/B parameters were 
580 581 582 583 584 585 586 587 588 589 590 591 592 593 594 595 596 597 598 599 600 601 602 603 604 605 606 607 608 609

estimated to estimate obtain reasonable P/Q values (Heymans et al., 2016)(Heymans et al., 2016)(Heymans et al., 2016) and so decreasing their pedigree index. These results highlighted the need to further develop studies develop studies focused on estimating specific growth and consumption ratios for species in Mediterranean MPAs.develop studies focused on estimating specific growth and consumption ratios in Mediterranean MPAs to charactherize and monitor MPAs within the Mediterranean Sea.

The flow diagram showed the first differences among MUs $\underline{P L s}$. Although the-TL were similar among three MUSPLs in each MPA, some commercial functional groups (e.g. FG 26 - groupers in Cerbère-Banyuls) showed slightly higher values for FPAs. This pattern could be due to the effect of protection in these areas, which may be connected with the complexity of the food web and the maturity of the ecosystem (Odum and Barrett, 1971)(Odum and Barrett, 1971)(Odum and Barrett, 1971).

Ecological indicators also showed differences among MUs $\underline{\mathrm{PLS}}$ and pointed out at the strong benefits of FPAs (Sala et al., 2017)(Sala et al., 2017)(Sala et al., 2017). FPAs (also known as no-take areas) are widely recognized as a powerful tool for ecosystem and biodiversity conservation (Claudet et al., 2008)(Claudet et al., 2008)(Claudet et al., 2008) and several studies have described their positive effects on biomass (Guidetti et al., 2014)(Guidetti et al., 2014)(Guidetti et al., 2014), trophic levels (Prato et al., 2016)(Guénette et al., 2014)(Guénette et al., 2014), mean length (Claudet et al., 2006)(Claudet et al., 2006)(Claudet et al., 2006), mean life span (Guénette and Pitcher, 1999)(Guénette and Pitcher, 1999)(Guénette and Pitcher, 1999), condition (Lloret and Planes, 2003)(Hloret and Planes, 2003)(Lloret and Planes, 2003) and biomass of IUCN species such as groupers (Claudet et al., 2008)(Claudet et al., 2008)(Claudet et al., 2008). ). Not surprisingly, biomass and trophic-based indicators results increased with the level of protection which demonstrated these positive effects of protection. This implies that FPAs promote higher fish weight and marine species abundance Not surprisingly, biomass and trophic-based indicators results increased with the level of protection which demonstrated these positive effects of protection. This implies that FPAs promote higher fish weight and marine species 
610 abundance-(Harmelin-Vivien et al., 2008). The increase in the TLs underlined the 611 applicability of FPAs as a conservation tool for large predatory fish species The 612 increase in the TLs underlined the applicability of FPAs as a conservation tool for 613 large predatory fish species-(Soler et al., 2015).

614 The same pattern was also found for TST, APL, and FCl, in which the value 615 of the indicator increases with the level of protection. These indicators suggested 616 lower stress, more maturity, larger ecological size and higher resilience 617 (Christensen, 1995) for FPAs ecosystems. In line with these results, Sala et al. 618 (2017) highlighted the potential benefits of FPAs and pointed out that these areas 619 are more resilient than UPAs. In our study In line with these results, consumption rate 620 over total system flows was higher in FPAs than PPA and UPA, since the higher the 621 biomass in the ecosystem the higher the consumption. Libralato et al. 622 (2010)(2010)(2010) found similar results for another Mediterranean MPA in the Adriatic 623 Sea due to the effect of protection. In addition, export and production ratio results 624 showed higher values for UPAs because the biomass of several FGs (such as 625 Sparidae or groupers) were quite high to support their feeding rates. So, these FGs 626 would migrate beyond the boundaries of the modelled ecosystem $(\mathrm{PL})$ to maintain 627 their feeding rates. The export results are also related to the fact that fisheries occur 628 in UPAs and PPAs in comparison with FPAs, where they are forbidden. The same 629 pattern was also found for TST, APL and FCl, in which the value of the indicator 630 increases with the level of protection. These indicators suggested lower stress, more 631 maturity, larger ecological size and higher resilience (Christensen, 632 1995)(Christensen, 1995) for FPAs ecosystems. In line with these results, Sala et al. 633 (2017)(2017) highlighted the potential benefits of FPAs and pointed out that these 634 areas are more resilient than UPAs.

635 Similarly, species based-indicators results showed a gradient among PLs. 636 reduces population abundance and mostly removing larger and older fish and so 637 decreasing the ML and MLS of fish in UPAs and increasing in the FPAs Fishing 638 reduces population abundance and mostly removing larger and older fish and so 639 decreasing the ML and MLS of fish in UPAs and increasing in the FPAs-(Lizaso et 
640 al., 2000). In addition, this pattern could also be due to large fish biomass with a 641 dominance of large apex predators such as Epinephelus marginatus In addition, this 642 pattern could also due to large fish biomass with a dominance of large apex 643 predators such as Epinephelus marginatus-(Hackradt et al., 2014). Similar results 644 were found for several MPAs in the Mediterranean Sea (Guidetti et al., 2014).

645 In addition, most biomass-based, trophic-based, species-based and flows646 based results obtained from PPAs demonstrated their role as buffer zones 647 (Giakoumi et al., 2017)(Giakoumi et al., 2017)(Giakoumi et al., 2017), so they may 648 confer biomass enhancement compared to UPAs although FPAs produce greater 649 benefits (Lester and Halpern, 2008; Sciberras et al., 2015)(Lester and Halpern, 650 2008; Sciberras et al., 2015)(Lester and Halpern, 2008; Sciberras et al., 2015). In 651 addition, export and production ratio results showed higher values for UPAs because 652 the biomass of several FGs (such as Sparidae or groupers) were quite high to 653 support their feeding rates. So, these FGs would migrate beyond the boundaries of 654 the modelled ecosystem $(\mathrm{PL})$ to maintain their feeding rates. The export results are 655 also related to the fact that fisheries occur in UPAs and PPAs in comparison with 656 FPAs, where they are forbidden.

657 In contrast, the Kempton's biodiversity index did not show the expected 658 pattern as biodiversity is expected to increase with protection In contrast, the 659 Kempton's bbiodiversity index (KI) did not show the expected pattern as biodiversity 660 is expected to increase with protection-(Costello and Ballantine, 2015)(Costello and 661 Ballantine, 2015)(Costello and Ballantine, 2015).- This controversial result could be due to 662 the available data, which came from different studies for each MPA. The Kempton's 663 biodiversity index may be biased since Cerbère-Banyuls model differs on the number 664 of functional groups compared to Cap de Creus and Medes Islands model 665 (Ainsworth and Pitcher, 2006). This controversial result could be due to the available 666 data, which came from different studies for each MPA. Using multiple studies for 667 each MPA could also bias this result because some studies showed biomass 668 estimates at higher taxonomic levels than others and the time period that these 669 models represent with regard to the creation year of the MPA. Therefore, as more 
670 exhaustive species biomass data are available, the biodiversity index becomes more 671 reliable Using multiple studies for each MPA may bias this result because some 672 studies showed biomass estimates at higher taxonomic levels than others and year. 673 Therefore, as more exhaustive species biomass data are available, the biodiversity 674 index becomes more reliable-(Claudet, 2013; Hereu Fina et al., 2017)(Claudet, 2013; 675 Hereu Fina et al., 2017)(Claudet, 2013; Hereu Fina et al., 2017). Although some 676 MPAs are not implemented for biodiversity purposes (Day et al., 2012), the great 677 differences of Kempton's biodiversity index between the FPA and the other two PL 678 areas in Cap de Creus could indicate that the PPA and the UPA marine populations 679 are not being replenished by new individuals coming from the FPA and so not 680 achieving the FPA's biodiversity value. The failure on the spillover effect in Cap de 681 Creus may be due to the lack of enforcement, the great differences of Kempton's 682 biodiversity index between the FPA and the other two PL areas in Cap de Creus 683 could indicate that the PPA and the UPA marine populations are not being 684 replenished by new individuals coming from the FPA and so not achieving the FPA's 685 biodiversity value. The failure on the spillover effect in Cap de Creus may be due to 686 the lack of enforcement-(Lloret et al., 2008a, 2008b), high fishing pressure in the 687 area (Lloret et al., 2008b) or the zonation and design of the MPA which is 688 represented by a fragmented PPA and a non-totally surrounded FPA. In addition, 689 export and production ratio results showed higher values for UPAs because the 690 biomass of several FGs (such as Sparidae or groupers) were quite high to support 691 their feeding rates. So, these FGs would migrate beyond the boundaries of the 692 modelled ecosystem (MU) to maintain their feeding rates. The export results are also 693 related to the fact that fisheries occur in UPAs and PPAs in comparison with FPAs, 694 where they are forbidden.

695 Overall, indicators displayed differences among MUsPLs within each MPA, 696 especially in the case of Cerbère-Banyuls and Medes Islands MPAs, but not for Cap 697 de Creus. Probably, these patterns could be explained by their enforcement, 698 reported to be a key factor to promote direct and indirect reserve effects (Guidetti et 699 al., 2008)(Guidetti et al., 2008)(Guidetti et al., 2008). The lack of enforcement is one 700 of the most relevant issues concerning MPAs in the Mediterranean context (Fenberg 
701 et al., 2012)(Fenberg et al., 2012)(Fenberg et al., 2012). Claudet and Guidetti 702 (2010)(2010)(2010) recognized that an MPA without enforcement and compliance is 703 just a paper park and no reserve effects can be expected. This could be the case of 704 Cap de Creus, in which our results did not show the same pattern found for the other 705 two MPAs. In fact, Lloret et al. (2008a, 2008b)(2008a, 2008b)(2008b, 2008a) reported a 706 lack of enforcement and a low level of compliance in Cap de Creus, particularly on

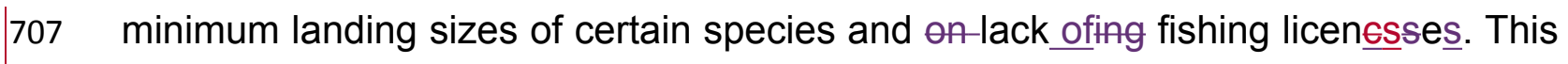
708 is in contrast with Cerbère-Banyuls and Medes Islands MPAs, in which compliance 709 and enforcement are ensured to promote a high level of ecological effectiveness (Di 710 Franco et al., 2016)(DiFranco et al., 2016)(DiFranco et al., 2016). Our results are 711 also consistent with previous studies performed in Cerbère-Banyuls (Harmelin712 Vivien et al., 2008)(Harmelin-Vivien et al., 2008)(Harmelin-Vivien et al., 2008) and 713 Medes Islands (Harmelin-Vivien et al., 2008; Sala et al., 2012)(Harmelin-Vivien et 714 al., 2008; Sala et al., 2012)(Harmelin-Vivien et al., 2008; Sala et al., 2012), which 715 demonstrated reserve effects for those MPAs and reported higher biomass in FPAs 716 with a rapid declineing from FPAs outward.

717 Giakoumi et al. (2017)(2017)(2017) revealed significant stronger biomass effect 718 for FPAs than PPAs and higher fish density in older, better enforced, and smaller 719 MPAs. Considering that Cap de Creus is the least enforced MPA in the study, our 720 results suggest that the level of enforcement and the-compliance have a strong effect 721 on MPA effectiveness at the ecosystem level. These patterns among MPAs were 722 also found by Horta e Costa et al. (2016)(2016)(2016) who presented a novel 723 classification system for MPAs which ranges from 1 (fully protected areas) to 8 724 (unprotected areas). In this scale, Cerbère-Banyuls obtained a rate of 4.7, being a 725 highly protected area, and Medes 6.4, being less well protected (Horta e Costa et 726 al., 2016)(Horta e Costa et al., 2016)(Horta e Costa et al., 2016). Cap de Creus was 727 not included in this study, but a higher MPA index can be assumed because of its 728 small FPA and its low compliance which increases the impact of fishing activities. 729 Overall, our results call for enhancement of the regulations, increasing the surface 730 extent of FPAs and the enforcement of management rules in Medes and Cap de 731 Creus MPA. 
732

733

734

735

736

737

738

739

740

741

742

743

744

745

746

747

748

749

750

751

752

753

754

755

756

757

758

759

760

761

All keystoneness indices for the nine models pointed out-at the same functional groups as keystones. Among them, groupers and common dentex were highlighted as keystone groups in previous western Mediterranean MPAs models (Valls et al., 2012; Prato et al., 2016)(Valls et al., 2012; Prato et al., 2016)(Prato et al., 2016b; Valls et al., 2012).

MPAs are considered an important tool to manage coastal fisheries (Claudet et al., 2006; Di Franco et al., 2016)(Claudet et al., 2006; Di Franco et al., 2016)(Claudet et al., 2006; DiFranco et al., 2016), and enforcement is a key aspect to achieve these goals. Our results showBiomass and catch-based results demonstrated that well-enforced small coastal MPAs can enhance small-scale and recreational fisheries by spillover effect and can promote the sustainability of local fisheries (Forcada et al., 2009; Goñi et al., 2011; Sala et al., 2013)(Forcada et al., 2009; Goñi et al., 2011; Sala et al., 2013)(Forcada et al., 2009; Goñi et al., 2011; Sala et al., 2013). According to the spillover effect, total catch and discards were higher in PPAs than in UPAs for all MPAs. Additionally, these differences on catches and discards between PPAs and UPAs can be explained by the concept of "fishing the line", which can reduce the biomass in neighbouring unprotected areas (Kellner et al., 2007)(Kellner et al., 2007)(Kellner et-al., 2007), so understanding spatialtemporal patterns of fishing effort around an MPA is a key aspect to manage and assess these areas. In this context, Stelzenmüller et al. (2008)(2008)(2008) found a local concentration of fishing effort around the borders of Cerbère-Banyuls and Medes Islands MPAs, in accordance with our results. On the other hand, although small-scale and recreational fisheries- are often considered to have a relatively low ecological impact, they do affect vulnerable species in coastal or offshore waters in the western Mediterranean Sea (including MPAs) through, targeted fishing or unintentional bycatch (Lloret et al., 2019)(Hloret et al., 2019)(Lloret et al., 2019).

\section{The results of PLs in Cap de Creus differed substantially from Cerbère-} Banyuls and Medes Islands. This could be related to the physical position of its FPA 
762 within a multi-use MPA, which for Cap de Creus is not located at the core of the MPA 763 surrounded by PPAs as is the common MPA design in the Mediterranean Sea The 764 results of MUs in Cap de Creus differed substantially from Cerbère-Banyuls and 765 Medes Islands. This could be related to the physical position of its FPA, which for 766 this MPA is not located at the core surrounded by PPAs as is the common MPA 767 design in the Mediterranean Sea-(Gabrié et al., 2012)(Gabrié et al., 2012)(Gabrié et 768 al., 2012). This unconventional placement could explain the observed reduction in 769 PPA effectiveness although this interpretation could be biased by the apparent lack 770 of enforcement in Cap de Creus. In MPAs, the maximum benefit to conservation and 771 ecosystem services will occur when FPAs are surrounded by well-managed fishing 772 grounds -(Roberts and Hawkins, 2000)(Roberts and Hawkins, 2000). This result 773 suggested the requirement of an implemented and non-fragmented PPA 774 surrounding the FPA in Cap de Creus which complements and ensures the 775 protection of the biodiversity in the FPA, as recommended in IUCN guidelines for 776 applying MPAs eseand non-fragmenteds (Day et al., 2012)(Day et al., 2012). This 777 unconventional placement could explain the observed reduction in PPA 778 effectiveness.

779 In addition, high values of total catch and discards in Cap de Creus could be 780 related to non-compliance, as well as to the lack of georeferenced catch data that 781 could have biased our results. Non-compliance could also result in some fishing 782 inside FPAs and PPAs, which may reduce the effectiveness of their potential 783 biological, ecological and fisheries benefits (Roberts, 2000)(Roberts, 2000)(Roberts, 784 2000), in accordance with the lack of enforcement above conclusions-obtained from 785 other ecological indicators (e.g. b-Biomass-based indicators). In additionAdditionally, 786 estimates of $\mathrm{V}$-vulnerability index and ML of the catch estimated values from Cap 787 de Creus could be explained as a failure in the enforcement in an MPA supporting-a 788 high fishing pressure from both small-scale and recreational fishing sectors (Lloret 789 and Font, 2013)(tloret and Font, 2013)(Horet and Font, 2013). Finally, our results 790 highlighted the impact of recreational fisheries in Cap de Creus among the rest of 791 studied MPAs, which could be also reducing MPA benefits (Lloret et al., 2008a, 792 2008b)(-Lloret et al., 2008a, 2008b)(Lloret et al., 2008b, 2008a). On the other hand, 


\begin{abstract}
793 the lower values of total catch and discards, the higher values of TL of the catch, ML 794 and MLS of fish in the catch, could reveal potential benefits of protection to adjacent 795 fisheries. Fishing pressure can lead to a decrease of TL of the catch, the higher 796 values of TL of the catch, ML and MLS of fish in the catch, which reveal potential 797 benefits of protection to adjacent fisheries. Fishing pressure can lead to a decrease 798 of TL of the catch (Shannon et al., 2014) and ML and MLS of fish in the catch 799 (Pelletier et al., 2005). Similarly, Prato et al. (2016) demonstrated that a decrease 800 in the fishing effort lead to an increase in the trophic level of the catch because of 801 increasing in fish predators biomass in Portofino MPA (Northwestern Mediterranean 802 Sea)demonstrated that a decrease on the fishing effort lead to an increase on the 803 trophic level of the catch because of increasing on fish predators biomass in 804 Portofino MPA (Northwestern Mediterranean Sea).
\end{abstract}

805

806

807 808 809

810

811

812

813 814 815 816

817

818 819 820 821

822

PPAs showed higher impacted values than UPAs, which suggest a higher contribution of PPAs to the recreational fishery. Although PPAs may differ on $\underline{\text { in }}$ their level of protection (Lester and Halpern, 2008)(tester and Halpern, 2008)(Lester and Halpern, 2008), for example ${ }_{2}$ spearfishing is not allowed inside the PPA of CerbèreBanyuls (Font et al., 2012b)(Font et al., 2012b)(Font et al., 2012b), these results confirmed their ecological effects and benefits for adjacent fisheries. Regarding the small scale fishery, the highest negative impacting values were represented by targeted species for this fleet, while positive values may represent FGs which are preys of those targeted species. Cerbère-Banyuls obtained higher impacting values than other MPAs. Since it is a well-well-enforced MPA, it could represent higher benefits or catches than other MPAs. In addition, most highlighted FGs by their high impacting values in small scale fishery matched with the keystone species, which support that non-enforced marine protected areas may compromise positive effects of these ecosystems (Claudet and Guidetti, 2010)(Claudet and Guidetti, 2010)(Claudet and Guidetti, 2010). Our results encourage fishermen compliance, which was identified as a key attribute for fisheries' success such as in Torre Guaceto MPA, where comanagement involving fishers, scientists and managers led to an increase in total 
823 fish biomass in FPA, an increase in fishermen's revenues when they operate within 824 the PPA and an increase in the commitment of local fishermen to environmental 825 issues (Di Franco et al., 2016)(DiFranco et al., 2016)(Di Franco et al., 2016).

The stronger benefits of FPAs than PPA and the importance of PPAs as a buffer area may suggest an alternative reorganization on the MPA zonation. An 828 increase on the surface or percentage of area covered by FPA could lead to more 829 resilient and productive MPAs which would enhance the benefits of ecosystem 830 services including adjacent fisheries. Additionally, PPAs must be surrounding the 831 FPA in order to ensure and complement the protection. Accordingly, MPA 832 configuration may obtain greater benefits when increasing the FPA surface and 833 ensuring its protection with a buffer PPA. MPAs and networks of MPAs can be used 834 to enhance the resilience, resistance in front perturbations or ecosystem 835 transformation in the face of climate change the e (Sala et al., 2017) (Day et al.., 836 2012)the and so spatial analysis should be included in future studies in order to 837 verify the benefits of new protection level zonations(Carr et al., 2017)(Carr et al., 838 2017). MPA zonation allows to assess the impacts of each protection level and 839 accommodate multiple objectives, human activities and stakeholder groups, and it is 840 a key aspect of the management of MPAs MPA zonation allows to assess the 841 impacts of each PL and accommodate multiple objectives, human activities and 842 stakeholder groups, and it is a key aspect of the management of MPAs-(Francour et 843 al., 2001; Lester and Halpern, 2008).

Even though our work illustrates that quantitative food-web modelling 846 techniques can be useful to assess coastal MPAs effects on the structural and 847 functional traits of marine ecosystems and their adjacent fisheries, some limitations 848 were faced. One of the main hurdles was the lack of local data for some FGs 849 identified in previous MPAs modelling studies (Libralato et al., 2010; Valls et al., 850 2012; Prato et al., 2016)(Libralato et al., 2010; Valls et al., 2012; Prato et al., 851 2016)(Libralato et al., 2010; Prato et al., 2016a; Valls et al., 2012). For example, 852 literature including benthonic biomass estimations inside MPAs is mainly focused on 
853 sea urchins, gorgonians and Posidonia meadows (e.g. HHereu Fina and Quintana Pou, 854 2012; Schvartz and Labbe, 2012)(Hereu Fina and Quintana Pou, 2012; Schvartz and Labbe, 855 2012)(Hereu et al., 2012; Schvartz and Labbe, 2012). However, studies on other important 856 benthic groups such as sponges or crustaceans are scarce. During the balancing 857 procedure, higher predation mortalities were found for several FGs in most 858 quantitative models and diet imports were set in order to ensure the mass-balance 859 for each model. Although these import values were set considering ecological and 860 size attributes of each FGs, small and open study areas could represent a limitation 861 of our models due to the lack of data and knowledgeDuring the balancing procedure, 862 higher predation mortalities were found for several FGs in most quantitative models 863 and diet imports were set in order to ensure the mass-balance. Although these import 864 values were set considering ecological and size attributes of each FGs and did not 865 influence modeling output, small study areas could represent a limitation for food866 web modeling. -Additionally, spatial-temporal series data of catches and fleet 867 distribution would improve the analysis on the effect of MPA potential benefits on the 868 recreational and small scale fisheries. Collecting time series of fishing activities 869 surrounding MPAs is a monitoring priority, as previously highlighted (Valls et al., 870 2012; Prato et al., 2016)(Valls et al., 2012; Prato et al., 2016)(Prato et al., 2016a; 871 Valls et al., 2012). A recent published study (Lloret et al., 2019)(Lloret et al., 872 2019)(Lloret et al., 2019), which focused in the Northwestern Mediterranean Sea, 873 emphasized the importance of differentiating between fishing methods or gears 874 when studying the impacts on vulnerable species in MPAs which could be 875 accomplished if data are available. Moreover, our results could be biased by the 876 oceanographic conditions and the zonation of the modelled MPAs (Heymans et al., 877 2016)(Heymans et al., 2016)(Heymans etal., 2016). In addition, and despite the fact 878 that these MPAs are closely located, the biomass estimations to develop the models 879 came from different reference years which could limit the comparison among MPAs 880 as a result of different environmental conditions (Sala et al., 2012)(Sala et al., 881 2012)(Sala et al., 2012).

882 Despite the limitations, this work represents to our knowledge the first attempt 883 to model management units within a protected area and it provides the basis to 
884 assess the role of these Mediterranean coastal areas within a network of MPAs using 885 a food-web modelling approach. These results highlight the capability of the EwE 886 modeling approach to capture protection effects in such small areas despite data 887 limitations. Our results suggest that enforcement can have an impact regarding on 888 the potential benefits of MPAs at the local scale, and a lack of enforcement is 889 noticeable in surrounding areas. MPAs can increase ecosystem maturity and 890 resilience and show potential benefits for small-scale fisheries that act in their 891 surroundings when these areas are well-enforced. Perceptions of ecological and 892 social benefits are key drivers of stakeholder support to MPAs and could therefore 893 reinforced a virtuous loop further enhancing MPA effects (Bennett et al., 894 2019)(Bennett et al., 2019)(Bennett et al., 2019). Future assessments on the spatial 895 distribution of marine resources and the role of these PLs within a network should 896 take place in order to quantify their impacts at a sub-regional (e.g. Northwestern 897 Mediterranean) and regional (e.g. Western Mediterranean) geographic 898 scales. Future assessments on the role of these MUs within a network should take 899 place in order to quantify their impacts at a sub-regional (e.g. Northwestern 900 Mediterranean) and regional (e.g. Western Mediterranean) geographic scales.

901 902 903 Acknowledgements

904 This work was funded by EU Research Project SAFENET project ("Sustainable 905 Fisheries in EU Mediterranean Waters through Network of MPAs." Call for proposals 906 MARE/2014/41, Grant Agreement n. 721708). D. Vilas benefited from a Short Term 907 Scientific Mission by the COST Action MarCons (CA15121).

References 


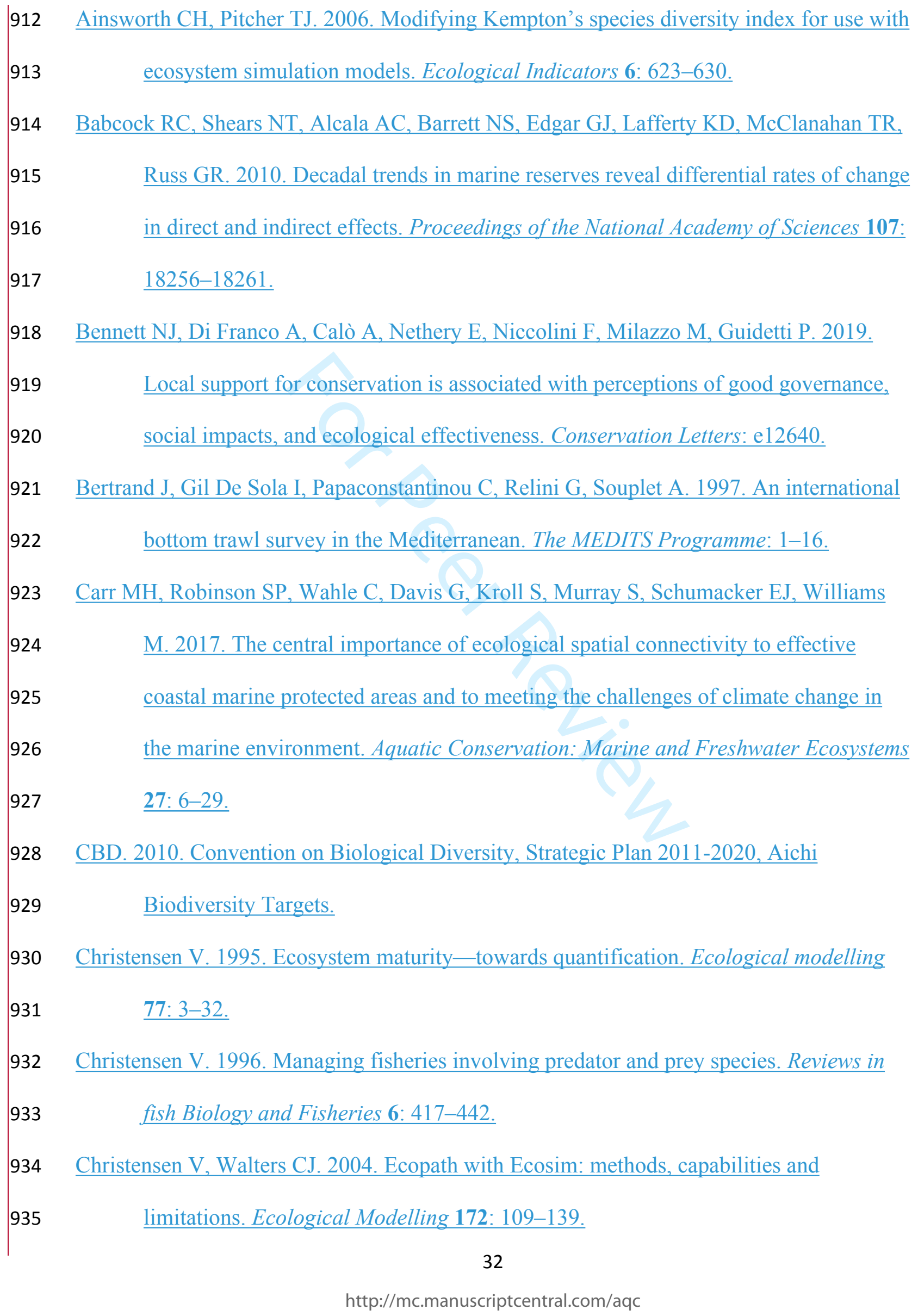


936 Christensen V, Walters CJ, Pauly D, Forrest R. 2008. Ecopath with Ecosim version 6: user 93 guide. November 2008. Fisheries Centre, University of British Columbia, Vancouver, Canada 235.

Claudet J. 2013. Unpubl. data. Underwater visual census of Cerbére-Banyuls Marine Protected Area.

941 Claudet J. 2018. Six conditions under which MPAs might not appear effective (when they are). ICES Journal of Marine Science 75: 1172-1174.

943 Claudet J, Guidetti P. 2010. Improving assessments of marine protected areas. Aquatic $944 \quad$ conservation: marine and freshwater ecosystems 20: 239-242.

945 Claudet J, Pelletier D, Jouvenel JY, Bachet F, Galzin R. 2006. Assessing the effects of $946 \quad$ marine protected area (MPA) on a reef fish assemblage in a northwestern Mediterranean marine reserve: Identifying community-based indicators. Biological Conservation 130: $349-369$.

949 Claudet J, Osenberg CW, Benedetti-Cecchi L, Domenici P, Garcia-Charton JA, Perez-

950 Ruzafa A, Badalamenti F, Bayle-Sempere J, Brito A, Bulleri F, et al. 2008. Marine

$951 \quad$ reserves: size and age do matter. Ecol Lett 11: 481-489.

952 Claudet J, Osenberg CW, Domenici P, Badalamenti F, Milazzo M, Falcón JM, Bertocci I, 953 Benedetti-Cecchi L, García-Charton J-A, Goñi R, et al. 2010. Marine reserves: Fish $954 \quad$ life history and ecological traits matter. Ecological Applications 20: 830-839.

955 Coll M, Steenbeek J. 2017. Standardized ecological indicators to assess aquatic food webs: 956 The ECOIND software plug-in for Ecopath with Ecosim models. Environmental $957 \quad$ Modelling \& Software 89: 120-130. 
958 Coll M, Vilas D, Corrales X, Piroddi C, Steenbeek J. 2019. Report describing the 959 quantitative models. Sustainable Fisheries in EU Mediterranean waters through network of MPAs - Safenet MARE/2014/41 Deliverable 4.2.:17

961 Costello MJ, Ballantine B. 2015. Biodiversity conservation should focus on no-take Marine Reserves: 94\% of Marine Protected Areas allow fishing. Trends in ecology \& evolution 30: 507-509.

964 Costello MJ, Coll M, Danovaro R, Halpin PN, Ojaveer H, Miloslavich P. 2010. A census of marine biodiversity knowledge, resources, and future challenges. PLOS ONE 5.

Dale MR, Fortin M-J. 2014. Spatial analysis: a guide for ecologists. Cambridge University Press.

Day J, Dudley N, Hockings M, Holmes G, Laffoley D d'A, Stolton S, Wells SM. 2012.

Guidelines for applying the IUCN protected area management categories to marine protected areas. IUCN.

971 Di Franco A. 2018. Databases on marine assemblages. Sustainable Fisheries in EU Mediterranean waters through network of MPAs - Safenet MARE/2014/41

974 Di Franco A, Thiriet P, Di Carlo G, Dimitriadis C, Francour P, Gutiérrez NL, De Grissac

Di Lorenzo M, Claudet J, Guidetti P. 2016. Spillover from marine protected areas to $\underline{\text { increase marine protected areas performance for small-scale fisheries management. }}$ adjacent fisheries has an ecological and a fishery component. Journal for Nature Conservation 32: 62-66. 


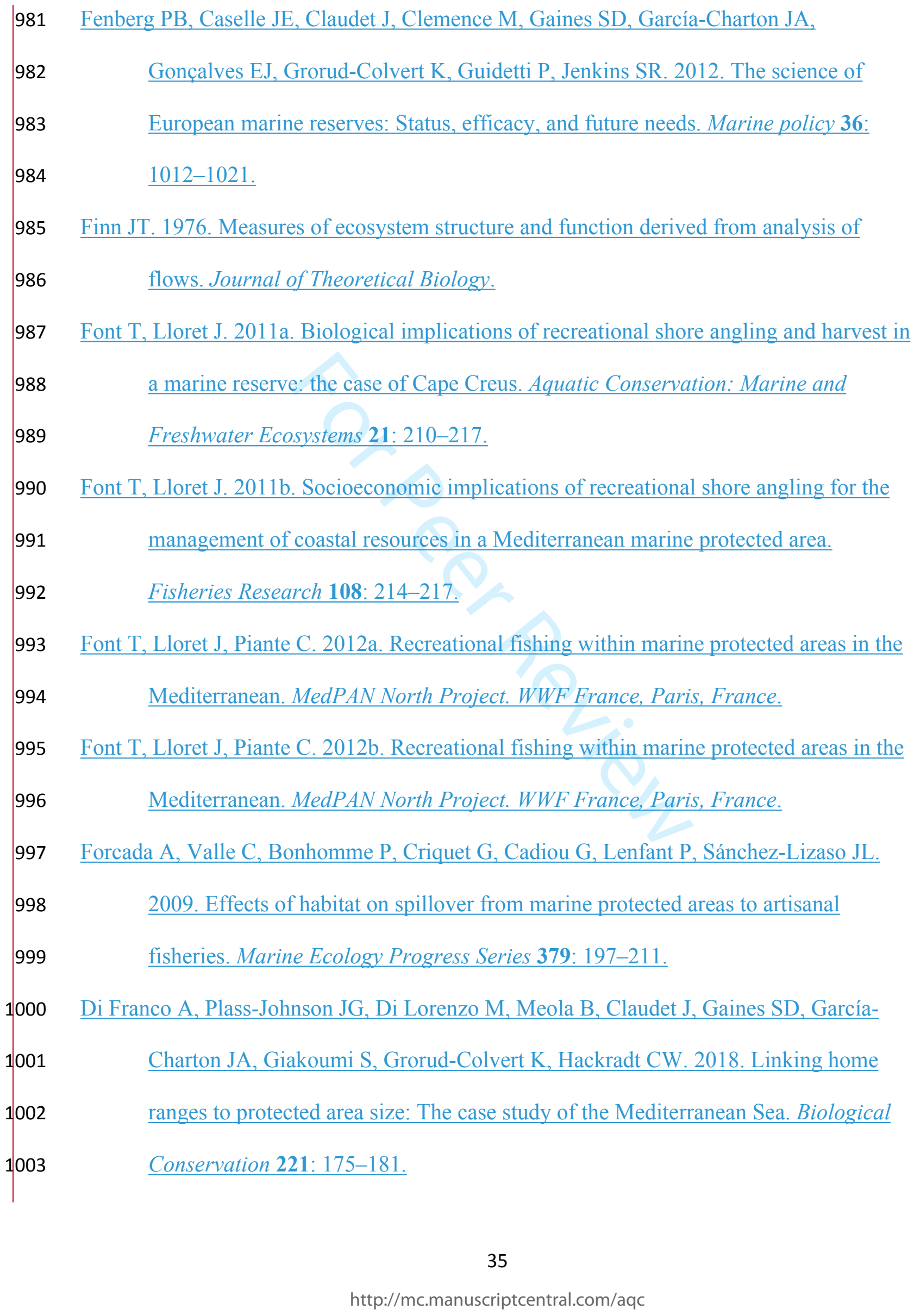


1004 Francour P, Harmelin J-G, Pollard D, Sartoretto S. 2001. A review of marine protected 1005

areas in the northwestern Mediterranean region: siting, usage, zonation and management. Aquatic conservation: marine and freshwater ecosystems 11: 155$1007 \underline{188 .}$

$1008 \quad$ Froese R, Pauly D. 2019. FishBase.

1009 Gabrié C, Lagabrielle E, Bissery C, Crochelet E, Meola B, Webster C, Claudet J, $1010 \quad$ Chassanite A, Marinesque S, Robert P. 2012. The status of marine protected areas in the mediterranean sea 2012. MedPAN Collection.

1012 García-Rubies A, Zabala i Limousin M. 1990. Effects of total fishing prohibition on the rocky fish assemblages of Medes Islands marine reserve (NW Mediterranean).

Gell FR, Roberts CM. 2003a. Benefits beyond boundaries: the fishery effects of marine

Gómez S, Lloret J, Demestre M, Riera V. 2006. The decline of the artisanal fisheries in Mediterranean coastal areas: the case of Cap de Creus (Cape Creus). Coastal reserves. Trends in Ecology \& Evolution 18: 448-455.

Gell FR, Roberts CM. 2003b. Benefits beyond boundaries: the fishery effects of marine reserves. Trends in Ecology \& Evolution 18: 448-455.

Giakoumi S, Scianna C, Plass-Johnson J, Micheli F, Grorud-Colvert K, Thiriet P, Claudet J, Di Carlo G, Di Franco A, Gaines SD. 2017. Ecological effects of full and partial protection in the crowded Mediterranean Sea: a regional meta-analysis. Scientific reports 7: 8940. Management 34: 217-232. 
1026 Goñi R, Badalamenti F, Tupper MH. 2011. Fisheries_Effects of Marine Protected Areas

1027

1028

1028

1029

(1)

1030

1031

1032

(1)

1033

103

(1)

1035

1036

1037

1038

1038

1039

1040

(1)

1041

1042

(1)

1043

1044

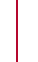

1045

1046

1047

1048

on Local Fisheries: Evidence from Empirical Studies. Marine Protected Areas: A Multidisciplinary Approach 72: 73.

Grüss A, Kaplan DM, Guénette S, Roberts CM, Botsford LW. 2011. Consequences of adult and juvenile movement for marine protected areas. Biological Conservation 144: $\underline{692-702 .}$

Guénette S, Pitcher TJ. 1999. An age-structured model showing the benefits of marine reserves in controlling overexploitation. Fisheries Research 39: 295-303.

Guidetti P, Milazzo M, Bussotti S, Molinari A, Murenu M, Pais A, Spanò N, Balzano R, Agardy T, Boero F, et al. 2008. Italian marine reserve effectiveness: Does enforcement matter? Biological Conservation 141: 699-709.

Guidetti P, Baiata P, Ballesteros E, Di Franco A, Hereu B, Macpherson E, Micheli F, Pais $\underline{\text { A, Panzalis P, Rosenberg AA. 2014. Large-scale assessment of Mediterranean }}$ marine protected areas effects on fish assemblages. PLoS One 9: e91841.

Hackradt CW, García-Charton JA, Harmelin-Vivien M, Perez-Ruzafa A, Le Direach L, Bayle-Sempere J, Charbonnel E, Ody D, Reñones O, Sanchez-Jerez P. 2014. $\underline{\text { Response of rocky reef top predators (Serranidae: Epinephelinae) in and around }}$ marine protected areas in the Western Mediterranean Sea. PloS one 9: e98206.

Halpern BS, Frazier M, Potapenko J, Casey KS, Koenig K, Longo C, Lowndes JS, Rockwood RC, Selig ER, Selkoe KA. 2015. Spatial and temporal changes in cumulative human impacts on the world's ocean. Nature communications 6: 7615.

Harmelin-Vivien M, Ledireach L, Baylesempere J, Charbonnel E, Garciacharton J, Ody D, Perezruzafa A, Renones O, Sanchezjerez P, Valle C. 2008. Gradients of abundance 
1049 1050 1051 1052 1053 1054 1055<smiles></smiles>

1072

and biomass across reserve boundaries in six Mediterranean marine protected areas:

Evidence of fish spillover? Biological Conservation 141: 1829-1839.

Hereu Fina B, Quintana Pou X. 2012. El fons marí de les illes Medes i el Montgrí: quatre dècades de recerca per a la conservació.

Hereu Fina B, Aspillaga Cuevas E, Atienza I, Burgués Martínez I, Capdevila Lanzaco P, Díaz Viñolas D, García-Rubies A, Linares Prats C, Mariani S, Martínez Ricart A. 2017. Seguiment del medi marí al Parc Natural del Cap de Creus i al Parc Natural del Montgrí, les Illes Medes i el Baix Ter. Memòria 2016.

Heymans JJ, Coll M, Libralato S, Morissette L, Christensen V. 2014. Global patterns in ecological indicators of marine food webs: a modelling approach. PloS one 9: $\underline{\mathrm{e} 95845 .}$

Heymans JJ, Coll M, Link JS, Mackinson S, Steenbeek J, Walters C, Christensen V. 2016. Best practice in Ecopath with Ecosim food-web models for ecosystem-based management. Ecological Modelling 331: 173-184.

Horta e Costa B, Claudet J, Franco G, Erzini K, Caro A, Gonçalves EJ. 2016. A regulationbased classification system for Marine Protected Areas (MPAs). Marine Policy 72: $\underline{192-198 .}$

Ivanoff P, Payrot J, Verdoit-Jarraya M. 2010. A recreational fishery survey inside and outside a marine protected area (north-western mediterranean) over one year: typology, seasonal variability and reserve's influence. Mémoire Master. Université Montpellier.

Kaschner K, Rius-Barile J, Kesner-Reyes K, Garilao C, Kullander S, Rees T, Froese R. 2013. AquaMaps. Predicted range maps for aquatic species World Wide Web electronic publication, Version 8: 2013. 
1073 Kellner JB, Tetreault I, Gaines SD, Nisbet RM. 2007. Fishing the line near marine reserves $1074 \quad$ in single and multispecies fisheries. Ecological Applications 17: 1039-1054. 1075 Lassalle G, Bourdaud P, Saint-Béat B, Rochette S, Niquil N. 2014. A toolbox to evaluate 1076 data reliability for whole-ecosystem models: application on the Bay of Biscay $1077 \quad$ continental shelf food-web model. Ecological modelling 285: 13-21.

1078 Lester SE, Halpern BS. 2008. Biological responses in marine no-take reserves versus 1079 partially protected areas. Marine Ecology Progress Series 367: 49-56.

Lester SE, Halpern BS, Grorud-Colvert K, Lubchenco J, Ruttenberg BI, Gaines SD, 1081 Airamé S, Warner RR. 2009. Biological effects within no-take marine reserves: a 1082 global synthesis. Marine Ecology Progress Series 384: 33-46.

1083 Libralato S, Coll M, Tempesta M, Santojanni A, Spoto M, Palomera I, Arneri E, Solidoro 1084 C. 2010. Food-web traits of protected and exploited areas of the Adriatic Sea. Biological Conservation 143: 2182-2194.

1086 Lizaso JS, Goñi R, Reñones O, Charton JG, Galzin R, Bayle JT, Jerez PS, Ruzafa AP, 1087 Ramos AA. 2000. Density dependence in marine protected populations: a review. $1088 \quad$ Environmental conservation 27: 144-158.

1089 Lloret J, Font T. 2013. A comparative analysis between recreational and artisanal fisheries $1090 \quad$ in a Mediterranean coastal area. Fisheries Management and Ecology 20: 148-160. 1091 Lloret J, Planes S. 2003. Condition, feeding and reproductive potential of white seabream Diplodus sargus as indicators of habitat quality and the effect of reserve protection in the northwestern Mediterranean. Marine Ecology Progress Series 248: 197-208. 1094 Lloret J, Zaragoza N, Caballero D, Font T, Casadevall M, Riera V. 2008a. Spearfishing 1095 pressure on fish communities in rocky coastal habitats in a Mediterranean marine protected area. Fisheries Research 94: 84-91. 
1097 Lloret J, Zaragoza N, Caballero D, Riera V. 2008b. Biological and socioeconomic 1098 implications of recreational boat fishing for the management of fishery resources in the marine reserve of Cap de Creus (NW Mediterranean). Fisheries Research 91: 252-259.

1101 Lloret J, Biton-Porsmoguer S, Carreño A, Di Franco A, Sahyoun R, Melia P, Claudet J,

Macpherson E, Gordoa A, Garcia-Rubies A. 2002. Biomass size spectra in littoral fishes in $\underline{\text { Seve C, Ligas A, Belharet M, et al. 2019. Recreational and small-scale fisheries }}$ may pose a threat to vulnerable species in coastal and offshore waters of the western Mediterranean. ICES Journal of Marine Science.

Lubchenco J, Grorud-Colvert K. 2015. Making waves: The science and politics of ocean protection. Science 350: $382-383$.

Marshall DJ, Gaines S, Warner R, Barneche DR, Bode M. 2019. Underestimating the

McClanahan TR, Mangi S. 2000. Spillover of exploitable fishes from a marine park and its benefits of marine protected areas for the replenishment of fished populations. protected and unprotected areas in the NW Mediterranean. Estuarine, Coastal and Shelf Science 55: 777-788. Frontiers in Ecology and the Environment 17: 407-413.

McCauley DJ, Pinsky ML, Palumbi SR, Estes JA, Joyce FH, Warner RR. 2015. Marine defaunation: Animal loss in the global ocean. Science 347: 1255641. effect on the adjacent fishery. Ecological applications 10: 1792-1805.

Micheli F, Halpern BS, Botsford LW, Warner RR. 2004. Trajectories and correlates of community change in no-take marine reserves. Ecological Applications 14: 17091723. 

1120 Morissette L. 2007. Complexity, cost and quality of ecosystem models and their impact on 1121 resilience: a comparative analysis, with emphasis on marine mammals and the Gulf of St. Lawrence. University of British Columbia.
Murawski SA, Wigley SE, Fogarty MJ, Rago PJ, Mountain DG. 2005. Effort distribution and catch patterns adjacent to temperate MPAs. ICES Journal of Marine Science 62: $1150-1167$.

Odum EP, Barrett GW. 1971. Fundamentals of Ecology. Volume 3. Thomson, Brooks/Cole. 1127 Pauly D. 1980. On the interrelationships between natural mortality, growth parameters, and $1128 \quad$ mean environmental temperature in 175 fish stocks. ICES Journal of Marine Science 39: 175-192.

1130 Pauly D, Watson R. 2005. Background and interpretation of the 'Marine Trophic Index'as a measure of biodiversity. Philosophical Transactions of the Royal Society B: Biological Sciences 360: 415-423.

1133 Pelletier D, García-Charton JA, Ferraris J, David G, Thébaud O, Letourneur Y, Claudet J, Amand M, Kulbicki M, Galzin R. 2005. Designing indicators for assessing the effects of marine protected areas on coral reef ecosystems: a multidisciplinary standpoint. Aquatic Living Resources 18: 15-33.

1137 Power ME, Tilman D, Estes JA, Menge BA, Bond WJ, Mills LS, Daily G, Castilla JC, $1138 \quad$ Lubchenco J, Paine RT. 1996. Challenges in the quest for keystones. BioScience 46: $1139 \quad$ 609-620.

1140 Prato G, Barrier C, Francour P, Cappanera V, Markantonatou V, Guidetti P, Mangialajo L, Cattaneo-Vietti R, Gascuel D. 2016. Assessing interacting impacts of artisanal and $\underline{\text { recreational fisheries in a small Marine Protected Area (Portofino, NW }}$ Mediterranean Sea). Ecosphere 7: e01601. 
$1144 \quad$ Prats L. 2016. Etude de la variabilité spatiale et temporelle dans la Réserve Naturelle Marine de Cerbère-Banyuls et à proximité : caractérisation de la pêche professionnelle, étude de l'effet réserve et des espèces à protéger (Msc thesis). $\mathrm{PhD}$ Thesis, Université de Pau et des Pays de L’Adour.

$1148 \quad$ R Core Team. 2017. R: A language and environment for statistical computing [Internet]. $1149 \quad$ Vienna, Austria; 2014.

1150 Roberts C, Hawkins JP. 2000. Fully-protected marine reserves: a guide. WWF Endangered seas campaign Washington, DC.

1152 Roberts CM. 2000. Selecting marine reserve locations: optimality versus opportunism. Bulletin of marine science 66: 581-592.

1154 Roncin N, Alban F, Charbonnel E, Crec'hriou R, de la Cruz Modino R, Culioli J-M, 1155 Dimech M, Goñi R, Guala I, Higgins R, et al. 2008. Uses of ecosystem services provided by MPAs: How much do they impact the local economy? A southern Europe perspective. Journal for Nature Conservation 16: 256-270.

1158 Sacanell M. 2012. Study on recreational fishing in the Medes Islands marine protected area. 1159 Technical Report to the Medes Islands Marine Reserve Management Authority: 52

$160 \quad$ pp.

1161 Sala E, Ballesteros E, Dendrinos P, Di Franco A, Ferretti F, Foley D, Fraschetti S, $1162 \quad$ Friedlander A, Garrabou J, Guclusoy H, et al. 2012. The structure of Mediterranean 163 rocky reef ecosystems across environmental and human gradients, and conservation $1164 \quad$ implications. PLoS One 7: e32742.

1165 Sala E, Costello C, Dougherty D, Heal G, Kelleher K, Murray JH, Rosenberg AA, Sumaila $1166 \quad$ R. 2013. A general business model for marine reserves. PLoS One 8: e58799. 
1167 Sala E, Giakoumi S, Pendleton H editor: L. 2017. No-take marine reserves are the most

1168

1169

1170

1171

171

1172

1173

174

1174

1175

1176

1177

1178

179

1179

1180

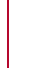

1181

1182

1183

1184

1185

186

1186

1187

1188

1189

effective protected areas in the ocean. ICES Journal of Marine Science 75: 11661168.

Sala E, Lubchenco J, Grorud-Colvert K, Novelli C, Roberts C, Sumaila UR. 2018. Assessing real progress towards effective ocean protection. Marine Policy 91: 1113.

$\underline{\text { Schvartz T, Labbe M. 2012. Suivi à long terme des communautés benthiques des substrats }}$ durs dans la Réserve Naturelle Marine de Cerbère-Banyuls.

$\underline{\text { Sciberras M, Jenkins SR, Mant R, Kaiser MJ, Hawkins SJ, Pullin AS. 2015. Evaluating the }}$ $\underline{\text { relative conservation value of fully and partially protected marine areas. Fish and }}$ Fisheries 16: 58-77.

$\underline{\text { Shannon L, Coll M, Bundy A, Gascuel D, Heymans JJ, Kleisner K, Lynam CP, Piroddi C, }}$ Tam J, Travers-Trolet M. 2014. Trophic level-based indicators to track fishing impacts across marine ecosystems. Marine Ecology Progress Series 512: 115-140.

Soler GA, Edgar GJ, Thomson RJ, Kininmonth S, Campbell SJ, Dawson TP, Barrett NS, Bernard AT, Galván DE, Willis TJ. 2015. Reef fishes at all trophic levels respond positively to effective marine protected areas. PLoS One 10: e0140270.

Steenbeek J. 2018a. MEDITS Data Explorer - Quick Reference Guide. Version 1.5.1, 26 June 2018. Safenet project - EU-DGMARE (MARE/2014/41), Barcelona.

Steenbeek J. 2018b. Diet Calculator - Quick Reference Guide. Version 0.8.5, 11 June 2018. $\underline{\text { Safenet project - EU-DGMARE (MARE/2014/41), Barcelona. }}$

Stelzenmüller V, Maynou F, Bernard G, Cadiou G, Camilleri M, Crec'hriou R, Criquet G, Dimech M, Esparza O, Higgins R. 2008. Spatial assessment of fishing effort around 
$1190 \quad$ European marine reserves: implications for successful fisheries management. Marine Pollution Bulletin 56: 2018-2026.

1192 Sumaila UR, Guénette S, Alder J, Chuenpagdee R. 2000. Addressing ecosystem effects of 1193 fishing using marine protected areas. ICES Journal of marine Science 57: 752-760.

1194 Tudó P. 2017. Unpubl. Data. Directorate of Fishing and Maritime Affairs, Government of

Catalonia, Avinguda Diagonal 523-525, 08029 Barcelona, Spain.

1196 Ulanowicz RE, Puccia CJ. 1990. Mixed trophic impacts in ecosystems. Coenoses: 7-16.

1197 Valls A, Gascuel D, Guénette S, Francour P. 2012. Modeling trophic interactions to assess 1198 the effects of a marine protected area: case study in the NW Mediterranean Sea. $1199 \quad$ Marine Ecology Progress Series 456: 201-214.

1200 Valls A, Coll M, Christensen V.2015. Keystone species: toward an operational concept for 1201 marine biodiversity conservation. Ecological Monographs 85: 29-47.

1202 Wickham H. 2010. ggplot2: elegant graphics for data analysis. J Stat Softw 35: 65-88. 1203 Zupan M, Bulleri F, Evans J, Fraschetti S, Guidetti P, Garcia-Rubies A, Sostres M, Asnaghi $\underline{\text { V, Caro A, Deudero S, et al. 2018a. How good is your marine protected area at }}$ curbing threats? Biological Conservation 221: 237-245.

1206 Zupan M, Fragkopoulou E, Claudet J, Erzini K, Costa BH e, Gonçalves EJ. 2018b. Marine 1207 partially protected areas: drivers of ecological effectiveness. Frontiers in Ecology $1208 \quad$ and the Environment 16: 381-387.

1209 Babcock RC, Shears NT, Alcala AC, Barrett NS, Edgar GJ, Lafferty KD, McClanahan TR. $1210 \quad$ Russ GR. 2010. Decadal trends in marine reserves reveal differential rates of change 1211 in direct and indirect effects. Proceedings of the National Academy of Sciences 107: 
1213 Bennett NJ, Di Franco A, Calò A, Nethery E, Niccolini F, Milazzo M, Guidetti P. 2019.

1214 Local support for conservation is associated with perceptions of good governance, social impacts, and ecological effectiveness. Conservation Letters: e12640.

Bertrand J, Gil De Sola I, Papaconstantinou C, Relini G, Souplet A. 1997. An internationat bottom traw1 survey in the Mediterranean. The MEDITS Programme: 1 16.

1218 Carr MH, Robinson SP, Wahle C, Davis G, Kroll S, Murray S, Schumacker EJ, Williams

$1219 \quad$ M. 2017. The central importance of ecological spatial connectivity to effective coastal marine protected areas and to meeting the challenges of climate change in 1221 the marine environment. Aquatic Conservation: Marine and Freshwater Ecosystems $1222 \quad \underline{27: 6-29}$.

CBD. 2010. Convention on Biological Diversity, Strategic Plan 2011-2020, Aichi

$1224 \quad$ Biodiversity Targets.

1225 Christensen V. 1995. Ecosystem maturity towards quantification. Ecological modelling $1226 \quad \underline{77: 3-32 .}$

1227 Christensen V. 1996. Managing fisheries involving predator and prey species. Reviews in $1228 \quad$ fish Biology and Fisheries 6:417-442.

1229 Christensen V, Walters CJ. 2004. Ecopath with Ecosim: methods, capabilities and $1230 \quad$ limitations. Ecological Modelling 172: 109-139.

1231 Christensen V, Walters CJ, Pauly D, Forrest R. 2008. Ecopath with Ecosim version 6: user guide. November 2008. Fisheries Centre, University of British Columbia, $1233 \quad$ Vancouver, Canada 235.

1234 Claudet J. 2013. Unpub1. data. Underwater visual census of Cerbére-Banyuls Marine $1235 \quad$ Protected Area. 
1236 Claudet J. 2018. Six conditions under which MPAs might not appear effective (when they are). ICES Journal of Marine Science 75: $1172 \quad 1174$.

1238 Claudet J, Guidetti P. 2010. Improving assessments of marine protected areas. Aquatic $1239 \quad$ eonservation: marine and freshwater ecosystems 20:239-242.

Claudet J, Pelletier D, Jouvenel JY, Bachet F, Galzin R. 2006. Assessing the effects of

marine protected area (MPA) on a reef fish assemblage in a northwestern

Mediterranean marine reserve: Identifying community based indicators. Biological

Claudet J, Osenberg CW, Benedetti-Cecchi L, Domenici P, Garcia-Charton JA, Perez Ruzafa A, Badalamenti F, Bayle-Sempere J, Brito A, Bulleri F, et al. 2008. Marine reserves: size and age do matter. Ecol Lett 11:481-489.

Claudet J, Osenberg CW, Domenici P, Badalamenti F, Milazzo M, Falcón JM, Bertocci I, Benedetti-Cecchi L, García-Charton J-A, Goñi R, et al. 2010. Marine reserves: Fish life history and ecological traits matter. Ecological Applications 20:830 839.

Coll M, Steenbeek J. 2017. Standardized ecological indicators to assess aquatic food webs: 1251 The ECOIND software plug in for Ecopath with Ecosim models. Environmentat Modelling \& Softure 89: $120 \quad 130$.

1253 Coll M, Vilas D, Corrales X, Piroddi C, Steenbeek J. 2019. Report describing the quantitative models. Sustainable Fisheries in EU Mediterranean waters through network of MPAs - Safenet MARE/2014/41 Deliverable 4.2.:17

1256 Costello MJ, Ballantine B. 2015. Biodiversity conservation should focus on no-take Marine evolution 30:507 509. 
1259 Costello MJ, Coll M, Danovaro R, Halpin PN, Ojaveer H, Miloslavich P. 2010. A census of 1260 marine biodiversity knowledge, resources, and future challenges. PLOS ONE 5.

1261 Dale MR, Fortin M-J. 2014. Spatial analysis: a guide for ecologists. Cambridge University $1262 \quad \underline{\text { Press. }}$

1263 Day J, Dudley N, Hockings M, Holmes G, Laffoley D-d'A, Stolton S, Wells SM. 2012. 1264 Guidelines for applying the IUCN protected area management categories to marine 1265 protected areas. IUCN.

Di Franco A. 2018. Databases on marine assemblages. Sustainable Fisheries in EU Mediterranean waters through network of MPAs-Safenet MARE/2014/41

Di Lorenzo M, Claudet J, Guidetti P. 2016. Spillover from marine protected areas to adjacent fisheries has an ecological and a fishery component. Journal for Nature Eonservation 32: 62 66.

1276 Fenberg PB, Caselle JE, Claudet J, Clemence M, Gaines SD, García-Charton JA, 1277 Gonçalves EJ, Grorud-Colvert K, Guidetti P, Jenkins SR. 2012. The science of European marine reserves: Status, efficacy, and future needs. Marine policy 36:

$1279 \underline{1012 \quad 1021}$

1280 Finn JT. 1976. Measures of ecosystem structure and function derived from analysis of 
1282 Font T, Lloret J. 2011a. Biological implications of recreational shore angling and harvest in 1283

Font T, Lloret J. 2011b. Socioeconomic implications of recreational shore angling for the management of coastal resources in a Mediterranean marine protected area.

$1287 \quad$ Fisheries Research 108: 214217.

1288 Font T, Lloret J, Piante C. 2012a. Recreational fishing within marine protected areas in the

Mediterranean. MedPAN North Project. WWF France, Paris, France.

1290 Font T, Lloret J, Piante C. 2012b. Recreational fishing within marine protected areas in the

Mediterranean. MedPAN North Project. WWF France, Paris, France.

1292 Forcada A, Valle C, Bonhomme P, Criquet G, Cadiou G, Lenfant P, Sánchez Lizaso JL.

2009. Effects of habitat on spillover from marine protected areas to artisanal

$1294 \quad$ fisheries. Marine Ecology Progress Series 379: $197 \quad 211$.

1295 Di Franco A, Plass-Johnson JG, Di Lorenzo M, Meola B, Claudet J, Gaines SD, García-

Charton JA, Giakoumi S, Grorud-Colvert K, Hackradt CW. 2018. Linking home ranges to protected area size: The case study of the Mediterranean Sea. Biological Eonservation 221: $175 \quad 181$.

1299 Francour P, Harmelin J-G, Pollard D, Sartoretto S. 2001. A review of marine protected areas in the northwestern Mediterranean region: siting, usage, zonation and management. Aquatic conservation: marine and freshwater ecosystems 11: 155

1302 $\underline{188 .}$

1303 Froese R, Pauly D. 2019. FishBase. 
1304 Gabrié C, Lagabrielle E, Bissery C, Crochelet E, Meola B, Webster C, Claudet J,

Chassanite A, Marinesque S, Robert P. 2012. The status of marine protected areas in the mediterranean sea 2012. MedPAN Collection.

García-Rubies A, Zabala i Limousin M. 1990. Effects of total fishing prohibition on the

rocky fish assemblages of Medes Istands marine reserve (NW Mediterranean).

Scientia Marina, 1990, vol. 54, num. 4, p. 317328.

1310 Gell FR, Roberts CM. 2003a. Benefits beyond boundaries: the fishery effects of marine reserves. Trends in Ecology \& Evolution 18: $448-455$.

1312 Gell FR, Roberts CM. 2003b. Benefits beyond boundaries: the fishery effects of marine reserves. Trends in Ecology \& Evolution 18: $448-455$.

1314 Giakoumi S, Scianna C, Plass-Johnson J, Micheli F, Grorud-Colvert K, Thiriet P, Claudet Jan

Di Carlo G, Di France A, Gaines SD. 2017. Ecological effects of full and partial protection in the crowded Mediterranean Sea: a regional meta-analysis. Scientific reports $7: 8940$.

1318 Gómez S, Lloret J, Demestre M, Riera V. 2006. The decline of the artisanal fisheries in $1319 \quad$ Mediterranean coastal areas: the case of Cap de Creus (Cape Creus). Coastat Management 34: $217 \quad 232$.

1321 Goñi R, Badalamenti F, Tupper MH. 2011. Fisheries Effects of Marine Protected Areas on Local Fisheries: Evidence from Empirical Studies. Marine Protected Areas: A Multidisciplinary Approach 72: 73.

1324 Grüss A, Kaplan DM, Guénette S, Roberts CM, Botsford LW. 2011. Consequences of adult and juvenile movement for marine protected areas. Biological Conservation 144: $\underline{692702 .}$ 
1327 Guénette S, Pitcher TJ. 1999. An age-structured model showing the benefits of marine reserves in controlling overexploitation. Fisheries Research 39: 295 303.

1329 Guidetti P, Milazzo M, Bussotti S, Molinari A, Murenu M, Pais A, Spanò N, Balzano R,

Agardy T, Boero F, et al. 2008. Italian marine reserve effectiveness: Does

enforcement matter? Biological Conservation 141: 699-709.

1332

Guidetti P, Baiata P, Ballesteros E, Di Franco A, Hereu B, Macpherson E, Micheli F, Pais

A, Panzalis P, Rosenberg AA. 2014. Large-scale assessment of Mediterranean marine protected areas effects on fish assemblages. PLoS One 9: e91841.

Hackradt CW, García-Charton JA, Harmelin-Vivien M, Perez Ruzafa A, Le Direach L,

Bayle-Sempere J, Charbonnel E, Ody D, Reñones O, Sanchez Jerez P. 2014.

Response of rocky reef top predators (Serranidae: Epinephelinae) in and around

marine protected areas in the Western Mediterranean Sea. PloS one 9: e98206.

Halpern BS, Frazier M, Potapenko J, Casey KS, Koenig K, Longo C, Lowndes JS.

Rockwood RC, Selig ER, Selkoe KA. 2015. Spatial and temporal changes in cumulative human impacts on the world's ocean. Nature communications 6: 7615.

1342 Harmelin-Vivien M, Ledireach L, Baylesempere J, Charbonnel E, Garciacharton J, Ody D, and biomass across reserve boundaries in six Mediterranean marine protected areas: Evidence of fish spillover? Biological Conservation 141: 1829-1839.

\section{Hereu Fina B, Quintana Pou X. 2012. E1 fons marí de les illes Medes i el Montgrí: quatre} dècades de recerca per a la conservació.

Hereu Fina B, Aspillaga Cuevas E, Atienza I, Burgués Martínez I, Capdevila Lanzaco P. Díaz Viñolas D, Gareía Rubies A, Linares Prats C, Mariani S, Martínez Ricart $\Lambda$. 
1352 Heymans J, Coll M, Libralato S, Morissette L, Christensen V. 2014. Global patterns in

ecological indicators of marine food webs: a modelling approach. Plos one 9:

$1354 \quad \underline{\text { e95845. }}$

1355

Heymans JJ, Coll M, Link JS, Mackinson S, Steenbeek J, Walters C, Christensen V. 2016.

Best practice in Ecopath with Ecosim food-web models for ecosystem-based management. Ecological Modelling 331: 173-184.

Horta e Costa B, Claudet J, Franco G, Erzini K, Caro A, Gonçalves EJ. 2016. A regulationbased classification system for Marine Protected Areas (MPAs). Marine Policy 72: 192198.

Ivanoff P, Payrot J, Verdoit-Jarraya M. 2010. A recreational fishery survey inside and outside a marine protected area (north-western mediterranean) over one year: typology, seasonal variability and reserve's influence. Mémoire Master. Université $1364 \quad$ Montpellier.

Kaschner K, Rius Barile J, Kesner-Reyes K, Garilao C, Kullander S, Rees T, Froese R. 2013. AquaMaps. Predicted range maps for aquatic species World Wide Web electronic publication, Version 8: 2013.

1368 Kellner JB, Tetreault I, Gaines SD, Nisbet RM. 2007. Fishing the line near marine reserves in single and multispecies fisheries. Ecological Applications 17: 1039-1054.

1370 Lassalle G, Bourdaud P, Saint-Béat B, Rochette S, Niquil N. 2014. A toolbox to evaluate data reliability for whole-ecosystem models: application on the Bay of Biscay eontinental shelf food web model. Ecological modelling 285: 1321. 
1373 Lester SE, Halpern BS. 2008. Biological responses in marine no-take reserves versus partially protected areas. Marine Ecology Progress Series 367:49-56.

1375 Lester SE, Halpern BS, Grorud Colvert K, Lubchenco J, Ruttenberg BI, Gaines SD,

Airamé S, Warner RR. 2009. Biological effects within no-take marine reserves: a

1377 global synthesis. Marine Ecology Progress Series 384: 33 -46.

1378 Libralato S, Coll M, Tempesta M, Santojanni A, Spoto M, Palomera I, Arneri E, Solidoro

$1379 \quad$ C. 2010. Food-web traits of protected and exploited areas of the Adriatic Sea.

Lizaso JS, Goñi R, Reñones O, Charton JG, Galzin R, Bayle JT, Jerez PS, Ruzafa AP,

Ramos AA. 2000. Density dependence in marine protected populations: a review. Environmental conservation 27: 144158.

Lloret J, Font T. 2013. A comparative analysis between recreational and artisanal fisheries in a Mediterranean coastal area. Fisheries Management and Ecology 20: 148 160.

Lloret J, Planes S. 2003. Condition, feeding and reproductive potential of white seabream Diplodus sargus as indicators of habitat quality and the effect of reserve protection in the northwestern Mediterranean. Marine Ecology Progress Series 248: 197208.

Eloret J, Zaragoza N, Caballero D, Font T, Casadevall M, Riera V. 2008a. Spearfishing pressure on fish communities in rocky coastal habitats in a Mediterranean marine protected area. Fisheries Research 94: 8491.

\section{Eloret J, Zaragoza N, Caballero D, Riera V. 2008b. Biological and socioeconomic} implications of recreational boat fishing for the management of fishery resources in the marine reserve of Cap de Creus (NW Mediterranean). Fisheries Research 91: $\underline{252 \quad 259 .}$ 
1396 1397

1398

Lloret J, Biton Porsmoguer S, Carreño A, Di Franco A, Sahyoun R, Melia P, Claudet Jo

Seve C, Ligas A, Belharet M, et al. 2019. Recreational and small-scale fisheries may pose a threat to vulnerable species in coastal and offshore waters of the western Mediterranean. ICES Journal of Marine Science.

1400 Eubchenco J, Grorud-Colvert K. 2015. Making waves: The science and polities of ocean protection. Science 350:382 383.

1402 Macpherson E, Gordoa A, Garcia-Rubies A. 2002. Biomass size spectra in littoral fishes in protected and unprotected areas in the NW Mediterranean. Estuarine, Coastal and $1404 \quad$ Shelf Science 55:777 788.

1405 Marshall DJ, Gaines S, Warner R, Barneche DR, Bode M. 2019. Underestimating the

$1406 \quad$ benefits of marine protected areas for the replenishment of fished populations.

1408 McCauley DJ, Pinsky ML, Palumbi SR, Estes JA, Joyce FH, Warner RR. 2015. Marine 1409 defaunation: Animal loss in the global ocean. Science 347: 1255641.

1410 McClanahan TR, Mangi S. 2000. Spillover of exploitable fishes from a marine park and its $1411 \quad$ effect on the adjacent fishery. Ecological applications 10: $1792 \quad 1805$.

1412 Micheli F, Halpern BS, Botsford LW, Warner RR. 2004. Trajectories and correlates of community change in no-take marine reserves. Ecological Applications 14: 1709 $\underline{1723 .}$

1415 Morissette L. 2007. Complexity, cost and quality of ecosystem models and their impact on $1416 \quad$ resilience: a comparative analysis, with emphasis on marine mammals and the Gulf of St. Lawrence. University of British Columbia. 
1418 Murawski SA, Wigley SE, Fogarty MJ, Rago PJ, Mountain DG. 2005. Effort distribution 1419 and catch patterns adjacent to temperate MPAs. ICES Journal of Marine Science

Odum EP, Barrett GW. 1971. Fundamentals of Ecology. Volume 3. Thomson, Brooks/Cole.

1422 Pauly D. 1980. On the interrelationships between natural mortality, growth parameters, and mean environmental temperature in 175 fish stocks. ICES Journal of Marine

Science 39: 175-192.

1425 Pauly D, Watson R. 2005. Background and interpretation of the 'Marine Trophic Index'as a measure of biodiversity. Philosophical Transactions of the Royal Society B: $1427 \quad$ Biological Sciences 360:415-423.

Pelletier D, García-Charton JA, Ferraris J, David G, Thébaud O, Letourneur Y, Claudet J.

Amand M, Kulbicki M, Galzin R. 2005. Designing indicators for assessing the effects of marine protected areas on coral reef ecosystems: a multidisciplinary standpoint. Aquatic Living Resources 18: $15 \quad 33$.

1432 Power ME, Tilman D, Estes JA, Menge BA, Bond WJ, Mills LS, Daily G, Castilla JC, Lubchenco J, Paine RT. 1996. Challenges in the quest for keystones. BioScience 46:

$1434 \quad \underline{609-620 .}$

Prato G, Barrier C, Francour P, Cappanera V, Markantonatou V, Guidetti P, Mangialajo L, Cattaneo-Vietti R, Gascuel D. 2016. Assessing interacting impacts of artisanal and recreational fisheries in a small Marine Protected Area (Portofino, NW

$1438 \quad$ Mediterranean Sea). Ecosphere 7: e01601.

1439 Prats L. 2016. Etude de la variabilité spatiale et temporelle dans la Réserve Naturelle

Marine de Cerbère Banyuls et à proximité : caractérisation de la pêche

\section{4}

http://mc.manuscriptcentral.com/aqc 
$1454 \quad$ Technical Report to the Medes Islands Marine Reserve Management Authority:52

1455 pp.

1456 Sala E, Ballesteros E, Dendrinos P, Di Franco A, Ferretti F, Foley D, Fraschetti $S_{9}$

Friedlander A, Garrabou J, Guclusoy H, et a1. 2012. The structure of Mediterranean rocky reef ecosystems across environmental and human gradients, and conservation implications. PLoS One 7: e32742.

1460 Sala E, Costello C, Dougherty D, Heal G, Kelleher K, Murray JH, Rosenberg AA, Sumaila

$1461 \quad$ R. 2013. A general business model for marine reserves. PLoS One 8: e58799.

1462 Sala E, Giakoumi S, Pendleton H editor: L. 2017. No-take marine reserves are the most 
1465 Sala E, Lubchenco J, Grorud-Colvert K, Novelli C, Roberts C, Sumaila UR. 2018.

Schvartz T, Labbe M. 2012. Suivi à long terme des communautés benthiques des substrats

Soler GA, Edgar GJ, Thomson RJ, Kininmonth S, Campbell SJ, Dawson TP, Barrett NS, Bernard AT, Galván DE, Willis TJ. 2015. Reef fishes at all trophic levels respond positively to effective marine protected areas. PLoS One 10: e0140270.

Steenbeek J. 2018a. MEDITS Data Explorer-Quick Reference Guide. Version 1.5.1, 26 June 2018. Safenet project - EUDGMARE (MARE/2014/41), Barcelona.

Steenbeek J. 2018b. Diet Caleulater Quick Reference Guide. Version 0.8.5, 11 June 2018. Safenet project - EUDGMARE (MARE/2014/41), Barcelona.

Stelzenmüller V, Maynou F, Bernard G, Cadiou G, Camilleri M, Crec'hriou R, Criquet G.

Dimech M, Esparza O, Higgins R. 2008. Spatial assessment of fishing effort around European marine reserves: implications for successful fisheries management. Marine Pollution Bulletin 56: 2018 2026.

Sumaila UR, Guénette S, Alder J, Chuenpagdee R. 2000. Addressing ecosystem effects of fishing using marine protected areas. ICES Journal of marine Science 57: $752 \quad 760$. 
1489

Tudó P. 2017. Unpubl. Data. Directorate of Fishing and Maritime Affairs, Government of Catalonia, Avinguda Diagonal 523-525,08029 Barcelona, Spain.

1491 Ulanowicz RE, Puccia CJ. 1990. Mixed trophic impacts in ecosystems. Coenoses: 7 16.

Valls A, Gascuel D, Guénette S, Francour P. 2012. Modeling trophic interactions to assess the effects of a marine protected area: case study in the NW Mediterranean Sea. Marine Ecology Progress Series 456: $201-214$.

Valls A, Coll M, Christensen V. 2015. Keystone species: toward an operational concept for marine biodiversity conservation. Ecological Monographs 85: 29-47.

Wickham H. 2010. ggplot2: elegant graphics for data analysis. J Stat Softw 35: 65 88.

Zupan M, Bulleri F, Evans J, Fraschetti S, Guidetti P, Garcia-Rubies A, Sostres M, Asnaghi $\underline{V}$, Caro A, Deudero $S$, et al. 2018a. How good is your marine protected area at eurbing threats? Biological Conservation 221: $237 \quad 245$.

1501 Zupan M, Fragkopoulou E, Claudet J, Erzini K, Costa BH e, Gonçalves EJ. 2018b. Marine partially protected areas: drivers of ecological effectiveness. Frontiers in Ecology and the Environment 16:381-387.

Babcock, R.C., Shears, N.T., Alcala, A.C., Barrett, N.S., Edgar, G.J., Lafferty, K.D., McClanahan, T.R., Russ, G.R., 2010. Decadal trends in marine reserves reveal differential rates of change in direct and indirect effects. Proc. Natl. Acad. Sci. 107, 18256-18261. https://doi.org/10.1073/pnas.0908012107

Bennett, N.J., Di Franco, A., Calò, A., Nethery, E., Niccolini, F., Milazzo, M., Guidetti, P., 2019. Local support for conservation is associated with perceptions of good governance, social impacts, and ecological effectiveness. Conserv. Lett. e12640.

CBD, 2010. Convention on Biological Diversity, Strategic Plan 2011-2020, Aichi Biodiversity Targets [WWW Document].

\section{7}

http://mc.manuscriptcentral.com/aqc 
1513 Christensen, V., 1996. Managing fisheries involving predator and prey species. Rev. Fish Biol. Fish.

$1514 \quad 6,417-442$.

Christensen, V., 1995. Ecosystem maturity - towards quantification. Ecol. Model.

Christensen, V., Walters, C.J., 2004. Ecopath with Ecosim: methods, capabilities and limitations. Ecol. Model. 172, 109-139. https://doi.org/10.1016/j.ecolmodel.2003.09.003

Christensen, V., Walters, C.J., Pauly, D., Forrest, R., 2008. Ecopath with Ecosim version 6: user guide. November 2008. Fish. Cent. Univ. Br. Columbia Vanc. Can. 235.

1521 Claudet, J., 2018. Six conditions under which MPAs might not appear effective (when they are). ICES J. Mar. Sci. 75, 1172-1174. https://doi.org/10.1093/icesjms/fsx074

1523 Claudet, J., 2013. Unpubl. data. Underwater visual census of Cerbére-Banyuls Marine Protected $1524 \quad$ Area.

1525 Claudet, J., Guidetti, P., 2010. Improving assessments of marine protected areas. Aquat. Conserv. Mar. Freshw. Ecosyst. https://doi.org/10.1002/aqc.1087

1527

Claudet, J., Osenberg, C.W., Benedetti-Cecchi, L., Domenici, P., Garcia-Charton, J.A., Perez-Ruzafa,

A., Badalamenti, F., Bayle-Sempere, J., Brito, A., Bulleri, F., Culioli, J.M., Dimech, M., Falcon, J.M., Guala, 1., Milazzo, M., Sanchez-Meca, J., Somerfield, P.J., Stobart, B., tett 11, 481-489. https://doi.org/10.1111/j.1461-0248.2008.01166.x Benedetti-Cecchi, L., García-Charton, J.-A., Goñi, R., Borg, J.A., Forcada, A., de Lucia, G.A., 1534 Pérez-Ruzafa, Á., Afonso, P., Brito, A., Guala, I., Diréach, L. Le, Sanchez-Jerez, P., Somerfield, P.J., Planes, S., 2010. Marine reserves: Fish life history and ecological traits matter. Ecol. Appl. 20,830-839. https://doi.org/10.1890/08-2131.1

58

http://mc.manuscriptcentral.com/aqc 
Claudet, J., Pelletier, D., Jouvenel, J.Y., Bachet, F., Galzin, R., 2006. Assessing the effects of marine protected area (MPA) on a reef fish assemblage in a northwestern Mediterranean marine reserve: Identifying community-based indicators. Biol. Conserv.

1541

Coll, M., Steenbeek, J., 2017. Standardized ecological indicators to assess aquatic food webs: The 130.

Coll, M., Steenbeek, J., Piroddi, C., Vilas, D., Corrales, X., 2019a. Report describing the qualitative Network models. Sustainable Fisheries in EU Mediterranean waters through network of MPAs-Safenet MARE/2014/41 Deliverable 4.1:17.

1547 Coll, M., Vilas, D., Corrales, X., Piroddi, C., Steenbeek, J., 2019b. Report describing the quantitative models. Sustainable Fisheries in EU Mediterranean waters through network of MPAs Safenet MARE/2014/41 Deliverable $4.2: 17$.

Costello, M.J., Ballantine, B., 2015. Biodiversity conservation should focus on no-take Marine Reserves: 94\% of Marine Protected Areas allow fishing. Trends Ecol. Evol. https://doi.org/10.1016/j.tree.2015.06.011

Difranco, A., 2018. Databases on marine assemblages. Sustainable Fisheries in EU Mediterranean waters through network of MPAs-Safenet MARE/2014/41 Deliverable 3.1.

Difranco, A., Plass-Johnson, J.G., DiLorenzo, M., Meola, B., Claudet, J., Gaines, S.D., García181.

Difranco, A., Thiriet, P., DiCarlo, G., Dimitriadis, C., Francour, P., Gutiérrez, N.L., De-Grissac, A.J., Koutsoubas, D., Milazzo, M., del Mar Otero, M., 2016. Five key attributes can increase 
1

2

3

4

5

6

7

8

9
1561

1562

1563

1564

1565

1566

1567

1568

1569

1570

1571

1572

1573

1574

1575

1576

1577

1578

1579

1580

1581

1582

1583

marine protected areas performance for small-scale fisheries management. Sci. Rep. 6, 38135.

DiLorenzo, M., Claudet, J., Guidetti, P., 2016. Spillover from marine protected areas to adjacent fisheries has an ecological and a fishery component. J. Nat. Conserv. 32, 62-66. https://doi.org/10.1016/j.jnc.2016.04.004

Fenberg, P.B., Caselle, J.E., Claudet, J., Clemence, M., Gaines, S.D., García-Charton, J.A., Gonçalves, E.J., Grorud-Colvert, K., Guidetti, P., Jenkins, S.R., 2012. The science of European marine reserves: Status, efficacy, and future needs. Mar. Policy 36, 1012-1021.

Finn, J.T., 1976. Measures of ecosystem structure and function derived from analysis of flows. J. Theor. Biol. https://doi.org/10.1016/S0022-5193(76)80080-X

Font, T., Lloret, J., Piante, C., 2012a. Recreational fishing within marine protected areas in the Mediterranean. MedPAN North Proj. WWF Fr. Paris Fr.

Font, T., Lloret, J., Piante, C., 2012b. Recreational fishing within marine protected areas in the Mediterranean. MedPAN North Proj. WWF Fr. Paris Fr.

Forcada, A., Valle, C., Bonhomme, P., Criquet, G., Cadiou, G., Lenfant, P., José, L.S.L., 2009. Effects of habitat on spillover from marine protected areas to artisanal fisheries. Mar. Ecol. Prog. Ser. https://doi.org/10.3354/meps07892

Fortin, M.J., Dale, M.R.T., 2005. Spatial analysis: A guide for ecologists, Spatial Analysis: A Guide for Ecologists. https://doi.org/10.1017/СВ09780511542039

Froese, R., Pauly, D., 2019. FishBase.

Gabrié, C., Lagabrielle, E., Bissery, C., Crochelet, E., Meola, B., Webster, C., Claudet, J., Chassanite, A., Marinesque, S., Robert, P., 2012. The status of marine protected areas in the mediterranean sea 2012. MedPAN Collection. 
1584 1585

1586

1587

1588

1589

1590

1591

1592

1593

1594

1595

1596

1597

1598

1599

1600

1601

1602

1604

1605

1606

1607

Gell, F.R., Roberts, C.M., 2003a. Benefits beyond boundaries: the fishery effects of marine reserves. Trends Ecol. Evol. 18, 448-455.

Gell, F.R., Roberts, C.M., 2003b. Benefits beyond boundaries: the fishery effects of marine reserves. Trends Ecol. Evol. 18, 448-455.

Giakoumi, S., Scianna, C., Plass-Johnson, J., Micheli, F., Grorud-Colvert, K., Thiriet, P., Claudet, J., Di Earlo, G., Di Franco, A., Gaines, S.D., 2017. Ecological effects of full and partial protection in the crowded Mediterranean Sea: a regional meta-analysis. Sci. Rep. 7, 8940.

Goñi, R., Badalamenti, F., Tupper, M.H., 2011. Fisheries-Effects of Marine Protected Areas on tocal Fisheries: Evidence from Empirical Studies. Mar. Prot. Areas Multidiscip. Approach $72,73$.

Grüss, A., Kaplan, D.M., Guénette, S., Roberts, C.M., Botsford, L.W., 2011. Consequences of adult and juvenile movement for marine protected areas. Biol. Conserv. 144, 692-702.

Guénette, S., Meissa, B., Gascuel, D., 2014. Assessing the contribution of marine protected areas to the trophic functioning of ecosystems: a model for the Banc d'Arguin and the Mauritanian shelf. PLoS One 9, e94742.

Guénette, S., Pitcher, T.J., 1999. An age-structured model showing the benefits of marine reserves in controlling overexploitation. Fish. Res. https://doi.org/10.1016/S0165-7836(98)00173-8

Guidetti, P., Baiata, P., Ballesteros, E., Di Franco, A., Hereu, B., Macpherson, E., Micheli, F., Pais, A., Panzalis, P., Rosenberg, A.A., Zabala, M., Sala, E., 2014. Large-scale assessment of mediterranean marine protected areas effects on fish assemblages. PLOS ONE. https://doi.org/10.1371/journal.pone.0091841

Guidetti, P., Milazzo, M., Bussotti, S., Molinari, A., Murenu, M., Pais, A., Spanò, N., Balzano, R., Agardy, T., Boero, F., Carrada, G., Cattaneo-Vietti, R., Cau, A., Chemello, R., Greco, S., Manganaro, A., di Sciara, G., Russo, G.F., Tunesi, L., 2008. Italian marine reserve 
1608 effectiveness: Does enforcement matter? Biol. Conserv. 141, 699-709. https://doi.org/10.1016/j.biocon.2007.12.013

Harmelin-Vivien, M., Ledireach, L., Baylesempere, J., Charbonnel, E., Garciacharton, J., Ody, D., Perezruzafa, A., Renones, O., Sanchezjerez, P., Valle, C., 2008. Gradients of abundance and biomass across reserve boundaries in six Mediterranean marine protected areas: Evidence ef fish spillover? Biol. Conserv. 141, 1829-1839. https://doi.org/10.1016/j.biocon.2008.04.029

1615 Hereu, B., Quintana, X., Hereu Fina, B., Quintana Pou, X., 2012. El fons marí de les illes Medes iet $1616 \quad$ Montgrí: quatre dècades de recerca per a la conservació.

Hereu Fina, B., Aspillaga Cuevas, E., Atienza, 1., Burgués Martínez, 1., Capdevila Lanzaco, P., Díaz Viñolas, D., García-Rubies, A., Linares Prats, C., Mariani, S., Martínez Ricart, A., 2017. Seguiment del medi marí al Pare Natural del Cap de Creus i al Parc Natural del Montgrí, les Hes Medes i el Baix Ter. Memòria 2016.

1621 Heymans, J.J., Coll, M., Libralato, S., Morissette, L., Christensen, V., 2014. Global patterns in ecological indicators of marine food webs: a modelling approach. Plos one 9, e95845.

1623 Heymans, J.J., Coll, M., Link, J.S., Mackinson, S., Steenbeek, J., Walters, C., Christensen, V., 2016. Best practice in Ecopath with Ecosim food-web models for ecosystem-based management. Ecol. Model. 331, 173-184. https://doi.org/10.1016/j.ecolmodel.2015.12.007

Horta e Costa, B., Claudet, J., Franco, G., Erzini, K., Caro, A., Gonçalves, E.J., 2016. A regulationbased classification system for Marine Protected Areas (MPAs). Mar. Policy 72, 192-198.

1628 Kellner, J.B., Tetreault, I., Gaines, S.D., Nisbet, R.M., 2007. Fishing the line near marine reserves in single and multispecies fisheries. Ecol. Appl. 17, 1039-1054. 
tassalle, G., Bourdaud, P., Saint-Béat, B., Rochette, S., Niquil, N., 2014. A toolbox to evaluate data reliability for whole-ecosystem models: application on the Bay of Biscay continental shelf food-web model. Ecol. Model. 285, 13-21.

tester, S.E., Halpern, B.S., 2008. Biological responses in marine no-take reserves versus partially protected areas. Mar. Ecol.Prog. Ser. https://doi.org/10.3354/meps07599

tester, S.E., Halpern, B.S., Grorud-Colvert, K., Lubchenco, J., Ruttenberg, B.I., Gaines, S.D., Airamé, S., Warner, R.R., 2009. Biological effects within no-take marine reserves: a global

1638 Libralato, S., Christensen, V., Pauly, D., 2006. A method for identifying keystone species in food 1639 web models. Ecol. Model. 195, 153-171. https://doi.org/10.1016/j.ecolmodel.2005.11.029

1640 Libralato, S., Coll, M., Tempesta, M., Santojanni, A., Spoto, M., Palomera, I., Arneri, E., Solidoro, C., 1641 2010. Food web traits of protected and exploited areas of the Adriatic Sea. Biol. Conserv. https://doi.org/10.1016/j.biocon.2010.06.002

Horet, J., Biton-Porsmoguer, S., Carreño, A., Di Franco, A., Sahyoun, R., Melia, P., Claudet, J., Seve, C., Ligas, A., Belharet, M., Calo, A., Carbonara, P., Coll, M., Corrales, X., Lembo, G., Sartor, P., Bitetto, I., Vilas, D., Piroddi, C., Prato, G., Charbonnel, E., Bretton, O., Hartmann, V., Prats, L., Font, T., 2019. Recreational and small-scale fisheries may pose a threat to vulnerable species in coastal and offshore waters of the western Mediterranean. ICESJ. Mar. Sci. https://doi.org/10.1111/j.1365-2400.2012.00868.* 
1

2

3

4

5

6

7

8

9

1652 Horet, J., Planes, S., 2003. Condition, feeding and reproductive potential of white seabream

1653 Diplodus sargus as indicators of habitat quality and the effect of reserve protection in the northwestern Mediterranean. Mar. Ecol. Prog. Ser. 248, 197-208.

1655 Horet, J., Zaragoza, N., Caballero, D., Font, T., Casadevall, M., Riera, V., 2008a. Spearfishing protected area. Fish. Res. 94, 84-91.

Horet, J., Zaragoza, N., Caballero, D., Riera, V., 2008b. Biological and socioeconomic implications of

tubchenco, J., Grorud-Colvert, K., 2015. Making waves: The science and politics of ocean protection. Science $350,382-383$.

Marshall, D.J., Gaines, S., Warner, R., Barneche, D.R., Bode, M., 2019. Underestimating the benefits of marine protected areas for the replenishment of fished populations. Front.

AcCauley, D.J., Pinsky, M.L., Palumbi, S.R., Estes, J.A., Joyce, F.H., Warner, R.R., 2015. Marine defaunation: Animalloss in the globalocean. Science 347, 1255641.

AcClanahan, T.R., Mangi, S., 2000. Spillover of exploitable fishes from a marine park and its effect 
Morissette, L., 2007. Complexity, cost and quality of ecosystem models and their impact on resilience: a comparative analysis, with emphasis on marine mammals and the Gulf of St. Lawrence. University of British Columbia.

Murawski, S.A., Wigley, S.E., Fogarty, M.J., Rago, P.J., Mountain, D.G., 2005. Effort distribution and eatch patterns adjacent to temperate MPAs. ICES J. Mar. Sci. 62, 1150-1167.

Odum, E.P., Barrett, G.W., 1971. Fundamentals of Ecology. Volume 3. Thomson BrooksCole.

Pauly, D., 1980. On the interrelationships between natural mortality, growth parameters, and mean environmental temperature in 175 fish-stocks. ICES J. Mar. Sci. 39, 175-192. https://doi.org/10.1093/icesjms/39.2.175

Pauly, D., Watson, R., 2005. Background and interpretation of the 'Marine Trophic Index'as a measure of biodiversity. Philos. Trans. R. Soc. B Biol. Sci. 360, 415-423.

Power, M.E., Tilman, D., Estes, J.A., Menge, B.A., Bond, W.J., Mills, L.S., Daily, G., Castilla, J.C., tubchenco, J., Paine, R.T., 1996. Challenges in the quest for keystones. BioScience 46, 609620.

Prato, G., Barrier, C., Francour, P., Cappanera, V., Markantonatou, V., Guidetti, P., Mangialajo, L., Eattaneo Vietti, R., Gascuel, D., 2016a. Assessing interacting impacts of artisanal and recreational fisheries in a small Marine Protected Area (Portofino, NW Mediterranean

1691 Sea). Ecosphere 7.

Prato, G., Barrier, C., Francour, P., Cappanera, V., Markantonatou, V., Guidetti, P., Mangialajo, L., Gattaneo Vietti, R., Gascuel, D., 2016b. Assessing interacting impacts of artisanal and recreational fisheries in a small Marine Protected Area (Portofino, NW Mediterranean 
Roberts, C.M., 2000. Selecting marine reserve locations: Optimality versus opportunism, in: Bulletin of Marine Science.

Roncin, N., Alban, F., Charbonnel, E., Crec'hriou, R., de la Cruz Modino, R., Culioli, J.-M., Dimech, M., Goñi, R., Guala, I., Higgins, R., Lavisse, E., Direach, L.L., Luna, B., Marcos, C., Maynou, F., Pascual, J., Person, J., Smith, P., Stobart, B., Szelianszky, E., Valle, C., Vaselli, S., Boncoeur, J., 2008. Uses of ecosystem services provided by MPAs: How much do they impact the local economy? A southern Europe perspective. J. Nat. Conserv., Special Issue on: European marine protected areas as tools for fisheries management and conservation 16, 256-270. https://doi.org/10.1016/j.jnc.2008.09.006

Sala, E., Ballesteros, E., Dendrinos, P., Di Franco, A., Ferretti, F., Foley, D., Fraschetti, S., Friedlander, A., Garrabou, J., Guclusoy, H., Guidetti, P., Halpern, B.S., Hereu, B., Karamanlidis, A.A., Kizilkaya, Z., Macpherson, E., Mangialajo, L., Mariani, S., Micheli, F., Pais, A., Riser, K., Rosenberg, A.A., Sales, M., Selkoe, K.A., Starr, R., Tomas, F., Zabala, M., 2012. The structure of Mediterranean rocky reef ecosystems across environmental and human gradients, and conservation implications. PLOS One 7, e32742. https://doi.org/10.1371/journal.pone.0032742

Sala, E., Costello, C., Dougherty, D., Heal, G., Kelleher, K., Murray, J.H., Rosenberg, A.A., Sumaila,

1715 R., 2013. A General Business Model for Marine Reserves. PLOSONE. https://doi.org/10.1371/journal.pone.0058799

Sala, E., Giakoumi, S., Pendleton, H. editor: L., 2017. No-take marine reserves are the most effective protected areas in the ocean. ICES J. Mar. Sci. 75, 1166-1168. real progress towards effective ocean protection. Mar. Policy 91, 11-13. 
1721 Schvartz, T., Labbe, M., 2012. Suivi àlong terme des communautés benthiques des substrats durs

1722

1723

1724

1725

1726

1727

1728

1728

1729

1730

1731

1732

1733

1734

1735

1736

1737

1738

1738

1739

1740

1741

1741 Zupan, M., Bulleri, F., Evans, J., Fraschetti, S., Guidetti, P., Garcia-Rubies, A., Sostres, M., Asnaghi,

1742

1743

1744 dans la Réserve Naturelle Marine de Cerbère-Banyuls.

Sciberras, M., Jenkins, S.R., Mant, R., Kaiser, M.J., Hawkins, S.J., Pullin, A.S., 2015. Evaluating the relative conservation value of fully and partially protected marine areas. Fish Fish. https://doi.org/10.1111/faf.12044

Steenbeek, J., 2018. Diet Calculator-Quick Reference Guide. Version 0.8.5, 11 June 2018. Safenet project - EU-DGMARE (MARE/2014/41), Barcelona.

Stelzenmüller, V., Maynou, F., Bernard, G., Cadiou, G., Camilleri, M., Crec'hriou, R., Criquet, G., Dimech, M., Esparza, O., Higgins, R., 2008. Spatial assessment of fishing effort around European marine reserves: implications for successful fisheries management. Mar. Pollut. Bull. 56, 2018-2026.

Sumaila, U.R., Guénette, S., Alder, J., Chuenpagdee, R., 2000. Addressing ecosystem effects of fishing using marine protected areas. ICES J. Mar. Sci. 57, 752-760.

Ulanowicz, R.E., Puccia, C.J., 1990. Mixed trophic impacts in ecosystems. Coenoses 7-16.

Valls, A., Coll, M., Christensen, V., 2015. Keystone species: toward an operational concept for marine biodiversity conservation. Ecol. Monogr. 85, 29-47.

Valls, A., Gascuel, D., Guénette, S., Francour, P., 2012. Modeling trophic interactions to assess the effects of a marine protected area: case study in the NW Mediterranean Sea. Mar. Ecol. Prog. Ser. 456, 201-214.

Wickham, H., 2010. ggplot2: elegant graphics for data analysis. J Stat Softw 35, 65-88. V., Caro, A., Deudero, S., Goñi, R., Guarnieri, G., Guilhaumon, F., Kersting, D., Kokkali, A., Kruschel, C., Macic, V., Mangialajo, L., Mallol, S., Macpherson, E., Panucci, A., Radolovic, M., Ramdani, M., Schembri, P.J., Terlizzi, A., Villa, E., Claudet, J., 2018a. How good is your 
1745
1746
1747
1748
1749

1750

1751

1752

1753

1754

1755

1756

1757

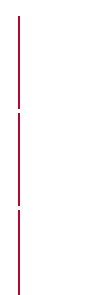

1758

1759 1760

1761 1762 1763 1764 marine protected area at curbing threats? Biol. Conserv. 221, 237-245.

https://doi.org/10.1016/j.biocon.2018.03.013

Zupan, M., Fragkopoulou, E., Claudet, J., Erzini, K., Costa, B.H. e, Gonçalves, E.J., 2018b. Marine partially protected areas: drivers of ecological effectiveness. Front. Ecol. Environ. 16, 381387. https://doi.org/10.1002/fee.1934

\section{Tables}

Table 1. Surface area $\left(\mathrm{km}^{2}\right)$ and the percentage covered by management unit (MU)protection level (PL) and year of creation of each marine protected area (MPA) (Cerbère-Banyuls, Cap de Creus and Medes Islands).

\begin{tabular}{ccccc}
\multirow{2}{*}{ MPA } & $\begin{array}{c}\text { Year of } \\
\text { creation }\end{array}$ & \multicolumn{3}{c}{ PLMU $\left(\mathbf{k m}^{2}\right)(\%)$} \\
\cline { 3 - 5 } & & FPA & PPA & UPA \\
\hline Cerbère-Banyuls & 1974 & $0.65 \underline{(1.59)}$ & $5.85 \underline{(14.32)}$ & $35.00 \underline{(85.68)}$ \\
\hline Cap de Creus & 1998 & $0.21 \underline{(0.69)}$ & $7.98 \underline{(26.11)}$ & $22.37(73.20)$ \\
\hline Medes Islands & 1983 & $0.39 \underline{(2.00)}$ & $4.24 \underline{(21.77)}$ & $14.85 \underline{(76.23)}$
\end{tabular}

Table 2. Functional groups included for the MU models showing those present (P) or absent (A) in each MPA. FG = Functional Group. Discards only are included in PPA and UPA models. 


\begin{tabular}{|c|c|c|c|c|}
\hline $\begin{array}{l}\text { FG } \\
\text { number }\end{array}$ & FG name & $\begin{array}{l}\text { Cerbère- } \\
\text { Banyuls }\end{array}$ & $\begin{array}{l}\text { Cap de } \\
\text { Creus }\end{array}$ & $\begin{array}{l}\text { Medes } \\
\text { Islands }\end{array}$ \\
\hline 4 & Bottlenose-dolphins & $P$ & $\mathrm{P}$ & $\mathrm{P}$ \\
\hline 2 & Striped dolphins & P & $P$ & $P$ \\
\hline 3 & $\begin{array}{l}\text { Endangered and pelagic } \\
\text { seabirds }\end{array}$ & $P$ & $P$ & $P$ \\
\hline 4 & Gulls and cormorants & $P$ & P & $P$ \\
\hline 5 & Terns & $\mathrm{P}$ & $\mathrm{P}$ & $P$ \\
\hline 6 & Loggerhead turtles & $P$ & $P$ & $P$ \\
\hline 7 & $\begin{array}{l}\text { Non-commercial large pelagic } \\
\text { fishes }\end{array}$ & $P$ & P & $P$ \\
\hline 8 & Other large pelagic fishes & P & P & P \\
\hline 9 & Mackerels & $\mathrm{P}$ & $\mathrm{P}$ & $\mathrm{P}$ \\
\hline 10 & Horse mackerels & $P$ & $P$ & $P$ \\
\hline 11 & Other medium pelagic fishes & $P$ & $\mathrm{P}$ & $P$ \\
\hline 12 & European sardine & $P$ & $\mathrm{P}$ & $\mathrm{P}$ \\
\hline 13 & European anchovy & $P$ & $P$ & $\mathrm{P}$ \\
\hline 14 & Round sardinella & A & $P$ & $\mathrm{P}$ \\
\hline 15 & Other small pelagic fish & $P$ & $P$ & $P$ \\
\hline 16 & Anglerfish & $P$ & $P$ & $\mathrm{P}$ \\
\hline 17 & European conger & $\mathrm{P}$ & $\mathrm{P}$ & $\mathrm{P}$ \\
\hline 18 & European hake & $P$ & $P$ & $P$ \\
\hline 19 & Poor cod & $P$ & $P$ & $P$ \\
\hline 20 & Common pandora & $P$ & $P$ & $\mathrm{P}$ \\
\hline 21 & Sparidae & $P$ & $P$ & $\mathrm{P}$ \\
\hline 22 & White seabream & $P$ & $P$ & $P$ \\
\hline 23 & $\begin{array}{l}\text { Common } \\
\text { seabream }\end{array}$ & $P$ & $P$ & $P$ \\
\hline 24 & Gommon dentex & $\mathrm{P}$ & $\mathrm{P}$ & $\mathrm{P}$ \\
\hline 25 & Red scorpionfish & $P$ & $P$ & $\mathrm{P}$ \\
\hline 26 & Scorpaenidae & $P$ & $P$ & $\mathrm{P}$ \\
\hline 27 & Groupers & $P$ & $P$ & $P$ \\
\hline 28 & Brown meagre & $P$ & $P$ & $P$ \\
\hline 29 & Labridae and Serranidae & $P$ & $P$ & $\mathrm{P}$ \\
\hline 30 & Flatfishes & $P$ & $P$ & $P$ \\
\hline 31 & $\begin{array}{l}\text { Other commercial medium } \\
\text { demersal fish }\end{array}$ & $P$ & $P$ & $P$ \\
\hline 32 & $\begin{array}{l}\text { No commercial medium } \\
\text { demersal fish }\end{array}$ & $P$ & $P$ & $P$ \\
\hline 33 & Salema & $P$ & $P$ & $\mathrm{P}$ \\
\hline 34 & Mugilidae & $P$ & $P$ & $\mathrm{P}$ \\
\hline 35 & Red mullet & $P$ & $P$ & $\mathrm{P}$ \\
\hline 36 & Striped red mullet & $P$ & $P$ & $\mathrm{P}$ \\
\hline 37 & $\begin{array}{l}\text { No commercial small demersal } \\
\text { fish }\end{array}$ & $P$ & $P$ & $\mathrm{P}$ \\
\hline 38 & Small-spotted catshark & $P$ & P & P \\
\hline 39 & Rays and skates & $P$ & $P$ & $P$ \\
\hline
\end{tabular}




\begin{tabular}{|ll}
40 & Torpedos \\
41 & Coastal benthic cephalopods \\
42 & Benthopelagic cephalopods \\
43 & Other benthic cephalopods \\
44 & Bivalves \\
45 & Gastropods \\
46 & Europeanlobster \\
47 & Other commercial decapods \\
48 & Non-commmercial decapods \\
49 & Purple sea urchin \\
50 & Other sea urchin \\
51 & Seacucumbers \\
52 & Other macro-benthos \\
53 & Jellyfish \\
54 & Salps and other gelatinous \\
55 & zooplankton \\
56 & Redcoral \\
57 & Other corals and gorgonians \\
58 & Macrozooplankton \\
59 & Meso and microzooplankton \\
60 & Suprabenthos \\
61 & Mediterranean seagrass \\
62 & Other seagrasses \\
63 & Erected algae \\
64 & Seaweeds \\
65 & Small phytoplankton \\
66 & Large phytoplankton \\
67 & Detritus \\
& Discards \\
&
\end{tabular}

$\begin{array}{lll}\text { b } & \text { p } & \text { b }\end{array}$

$\begin{array}{lll}\text { b } & \text { P } & \text { P }\end{array}$

P $\quad$ P $\quad$ P

$\begin{array}{lll}\text { P } & \text { P } & \text { P }\end{array}$

$\begin{array}{lll}\text { P } & \text { P } & \text { P }\end{array}$

$\begin{array}{lll}\text { P } & \text { P } & \text { P }\end{array}$

$\begin{array}{lll}\text { P } & \text { P } & \text { P }\end{array}$

$\begin{array}{lll}\text { P } & \text { P } & \text { P }\end{array}$

$\begin{array}{lll}\text { P } & \text { P } & \text { P }\end{array}$

$\begin{array}{lll}P & P & P\end{array}$

$\begin{array}{lll}\text { P } & \text { P } & \text { P }\end{array}$

$\begin{array}{lll}\text { P } & \text { P } & \text { P }\end{array}$

$\begin{array}{lll}\text { P } & \text { P } & \text { P }\end{array}$

$\begin{array}{lll}\text { P } & \text { P } & \text { P }\end{array}$

$\begin{array}{lll}P & P & P\end{array}$

1765

1766

$\begin{array}{lll}\text { P } & \text { P } & \text { P }\end{array}$

$\begin{array}{lll}P & P & P\end{array}$

$\begin{array}{lll}\mathrm{P} & \mathrm{P} & \mathrm{P}\end{array}$

$\begin{array}{lll}P & P & P\end{array}$

$\begin{array}{lll}\text { P } & \text { P } & \text { P }\end{array}$

$\begin{array}{lll}P & P & P\end{array}$

A $P$ P

$\begin{array}{lll}A & P & P\end{array}$

$\begin{array}{lll}\text { P } & \text { P } & \text { P }\end{array}$

$\begin{array}{lll}P & P & P\end{array}$

$\begin{array}{lll}P & P & P\end{array}$

P $P$ P

P $P$

P

1767

1768

1769

1770

1771

1772

1773 


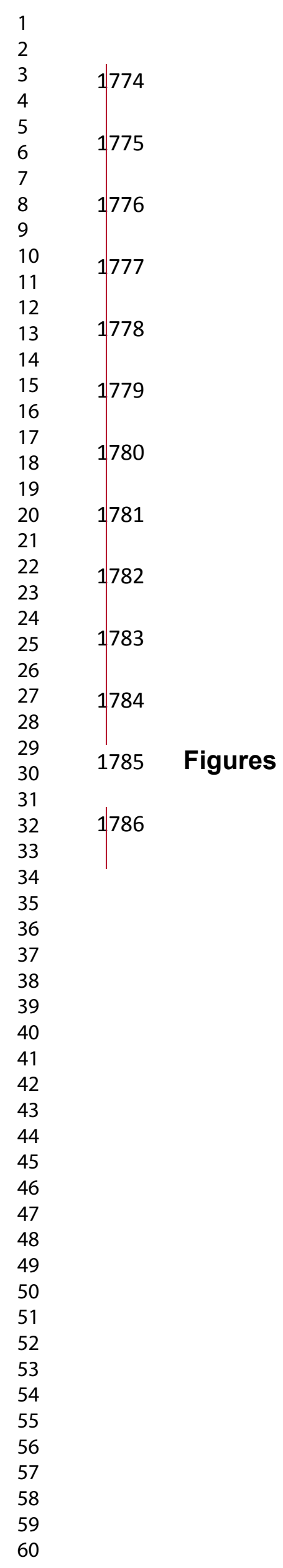




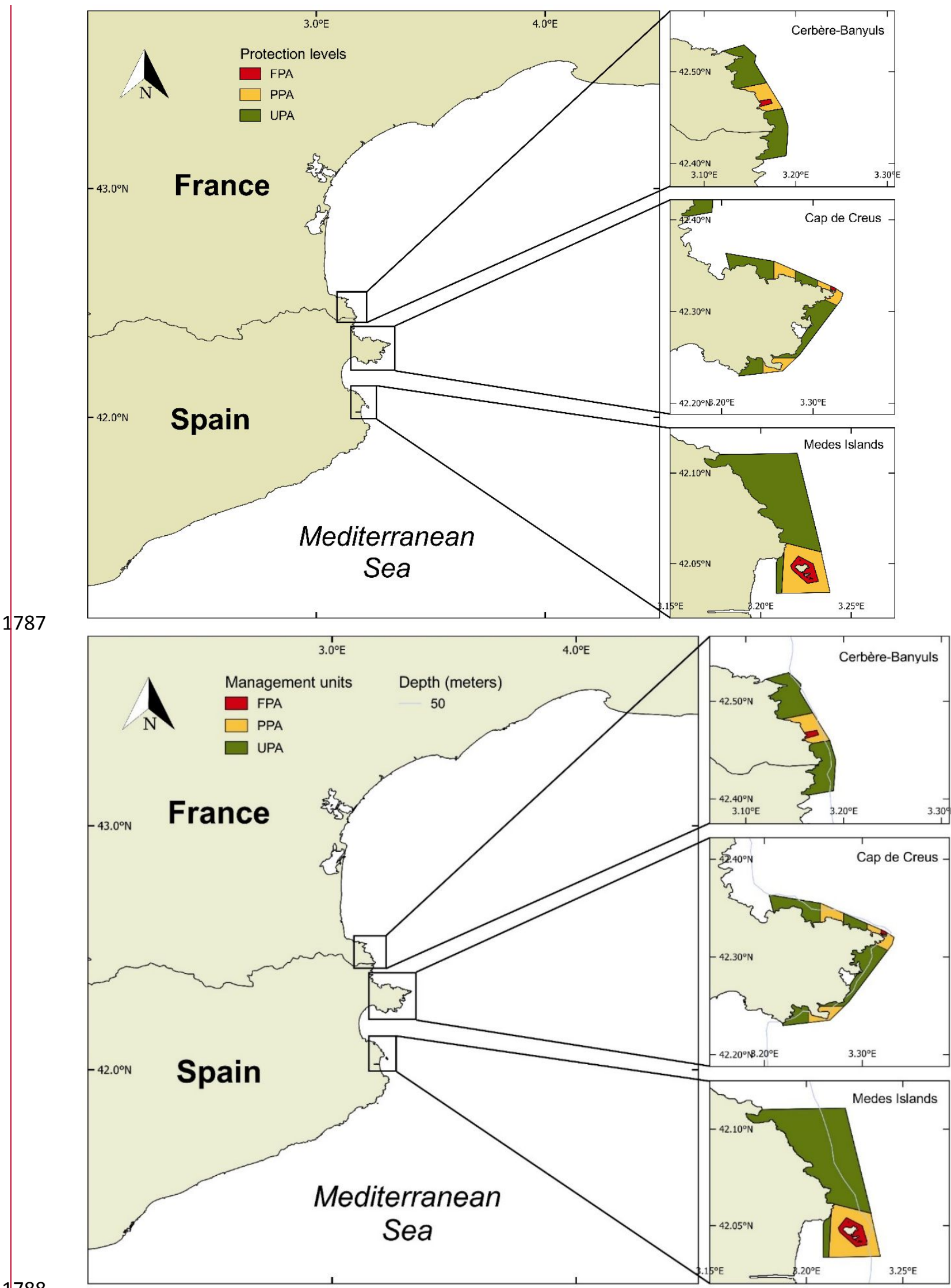


1789 Figure 1. Location of the three MPAs and their AUsprotection levels (PL) PLs-(FPA: 1790 fully protected area; PPA: partially protected area; UPA: unprotected area) in 1791 Cerbère-Banyuls, Cap de Creus and Medes Islands.

1792

1793

1794

1795

1796 


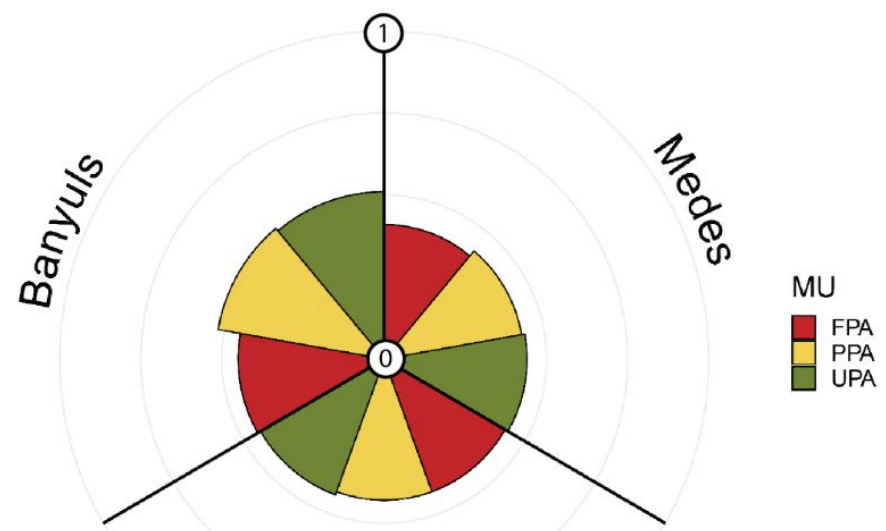

\section{Cap de Creus}

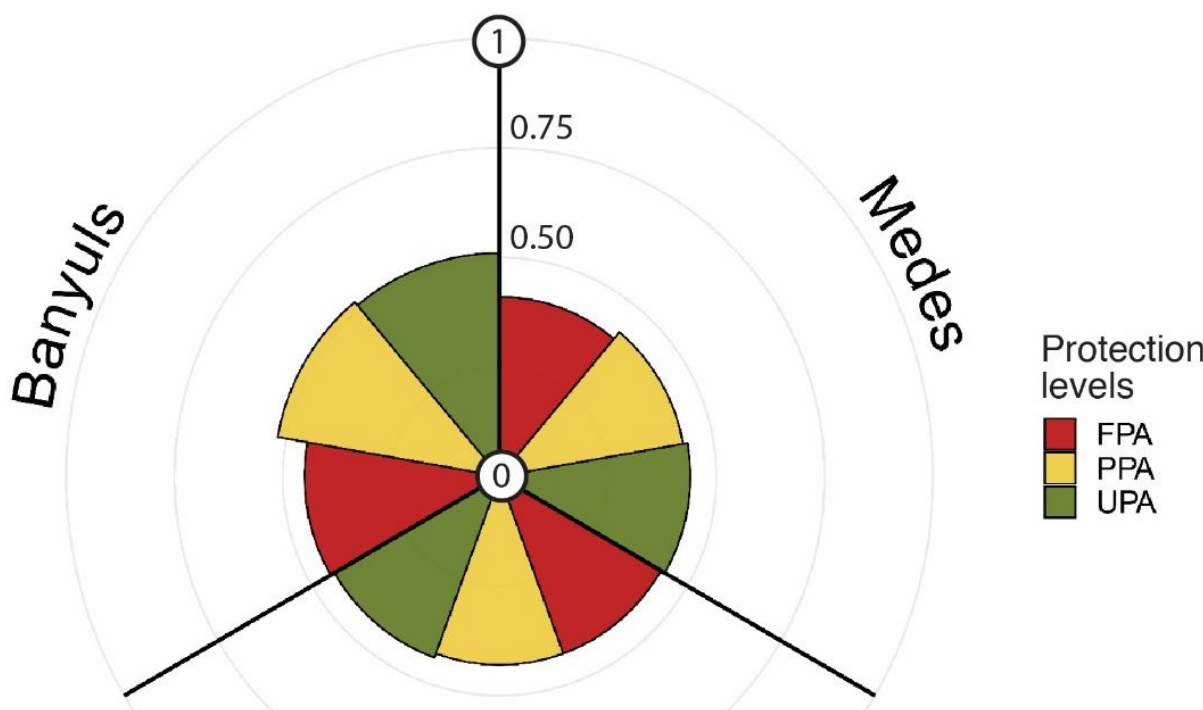

\section{Cap de Creus}

Figure 2. Pedigree index values of the three MUsprotection levels (PL)PLs models (FPA: fully protected area; PPA: partially protected area; UPA: unprotected area) for 1800 each MPA (Cerbère-Banyuls, Cap de Creus and Medes Islands). 


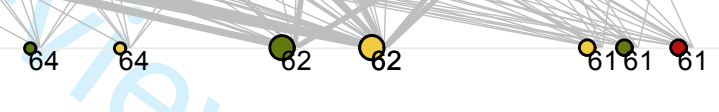

Figure 3. Flow diagrams of three management unitsprotection levels (PL)PLs_(FPA: red; PPA: yellow; UPA: green) of Cerbère-Banyuls MPA model organized by trophic levels $(T L)$ (y-axis). The size of each circle is proportional to the biomass 1816 of the functional group. The wideness of the connecting lines is proportional to the magnitude of their flows. The numbers 1817 identify the functional groups of the PLMU models (Appendix 1 supplementary material) (Flow diagrams of Cap de Creus 1818 and Medes Islands MPA can be found in supplementary material Figure S5S6.1.). 

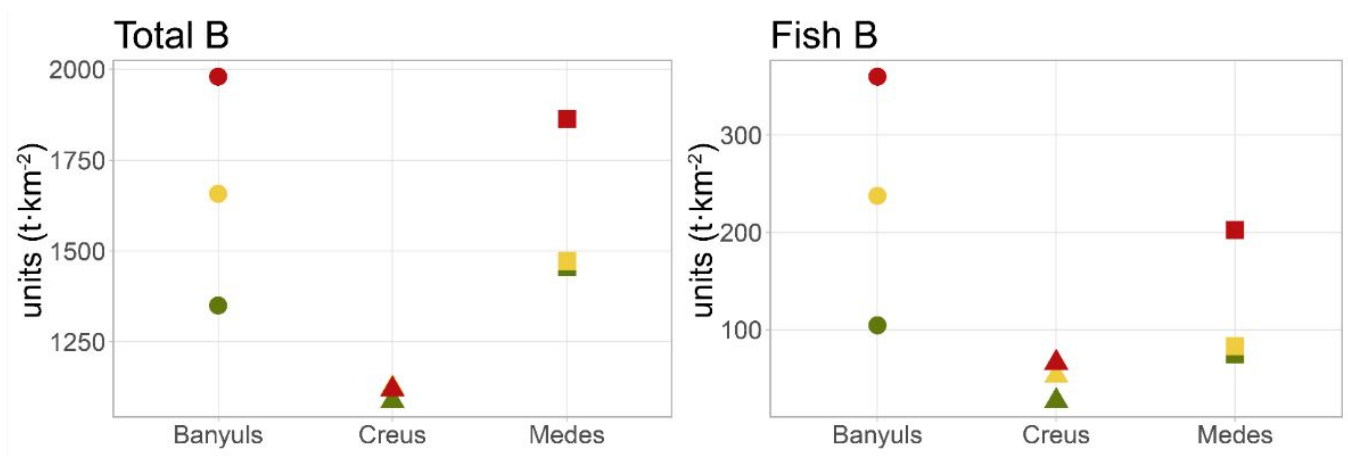

PL
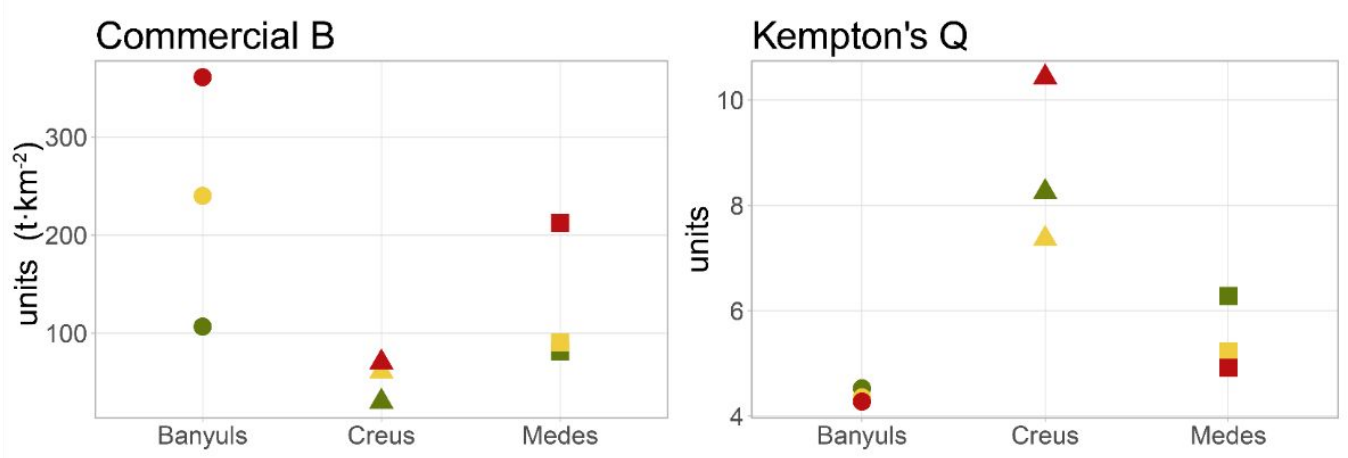

- FPA

- PPA

- UPA

Figure 4. Biomass-based indicators of the three AUsPLprotection levels (PL) (FPA: fully protected area; PPA: partially protected area; UPA: unprotected area) models for each MPA (Cerbère-Banyuls, Cap de Creus and Medes Islands). (B - Biomass, Kempton's $Q$ - Kempton's $Q$ diversity index). 

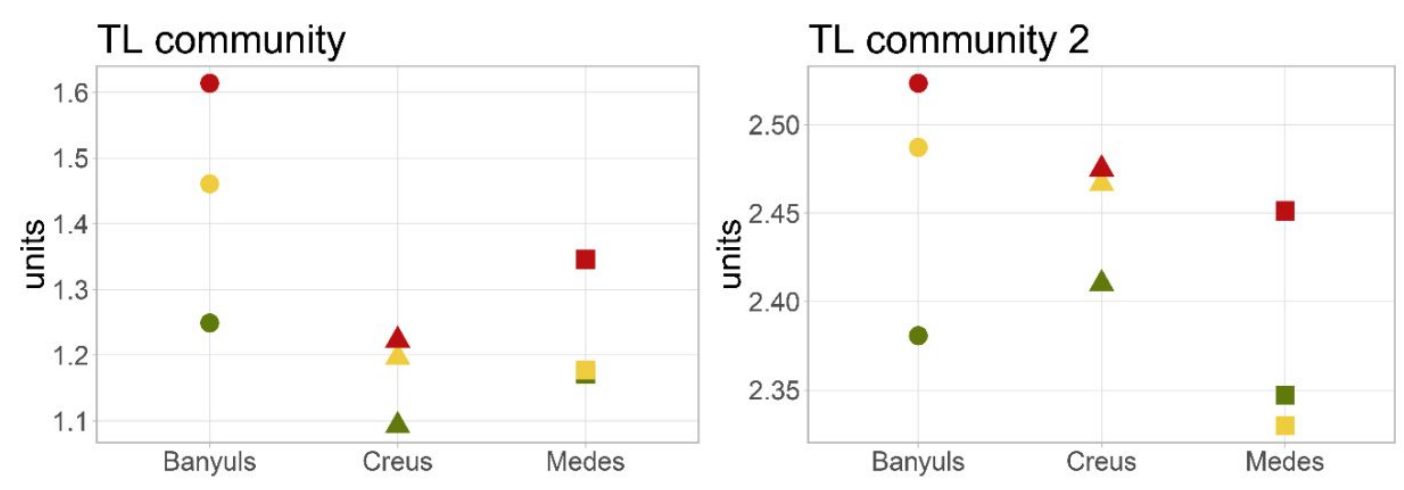

$\mathrm{PL}$

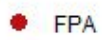

- PPA

- UPA
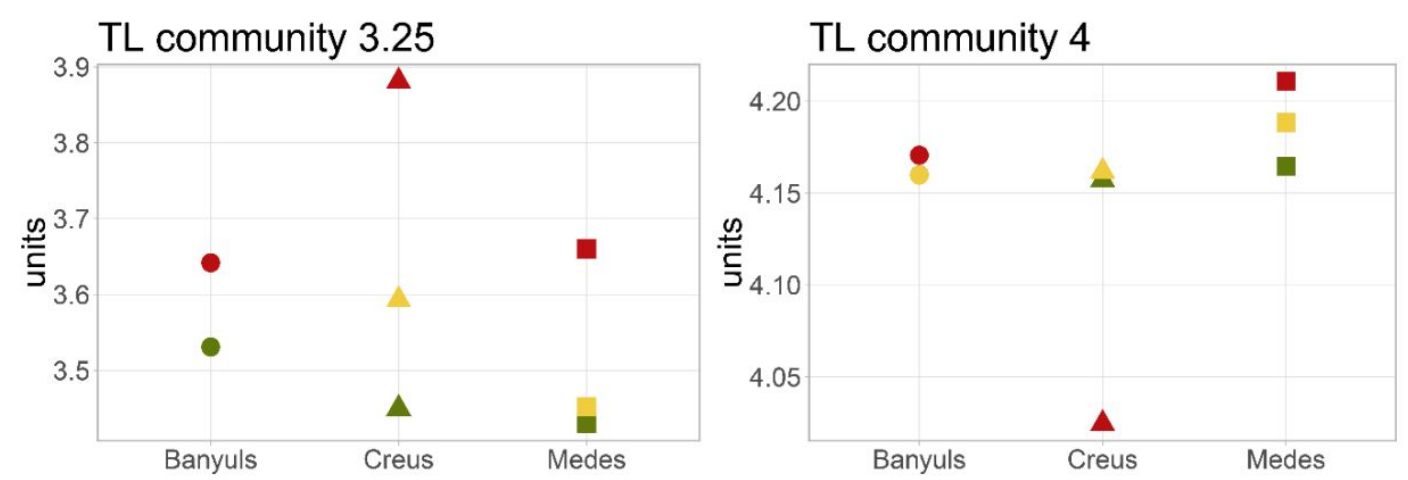

MPA

- Banyuls

- Creus

- Medes

Figure 5. Trophic-based indicators of the three AUsprotection levels (PL)PLs (FPA: fully protected area; PPA: partially protected area; UPA: unprotected area) models for each MPA (Cerbère-Banyuls, Cap de Creus and Medes Islands). (TL - trophic level). 

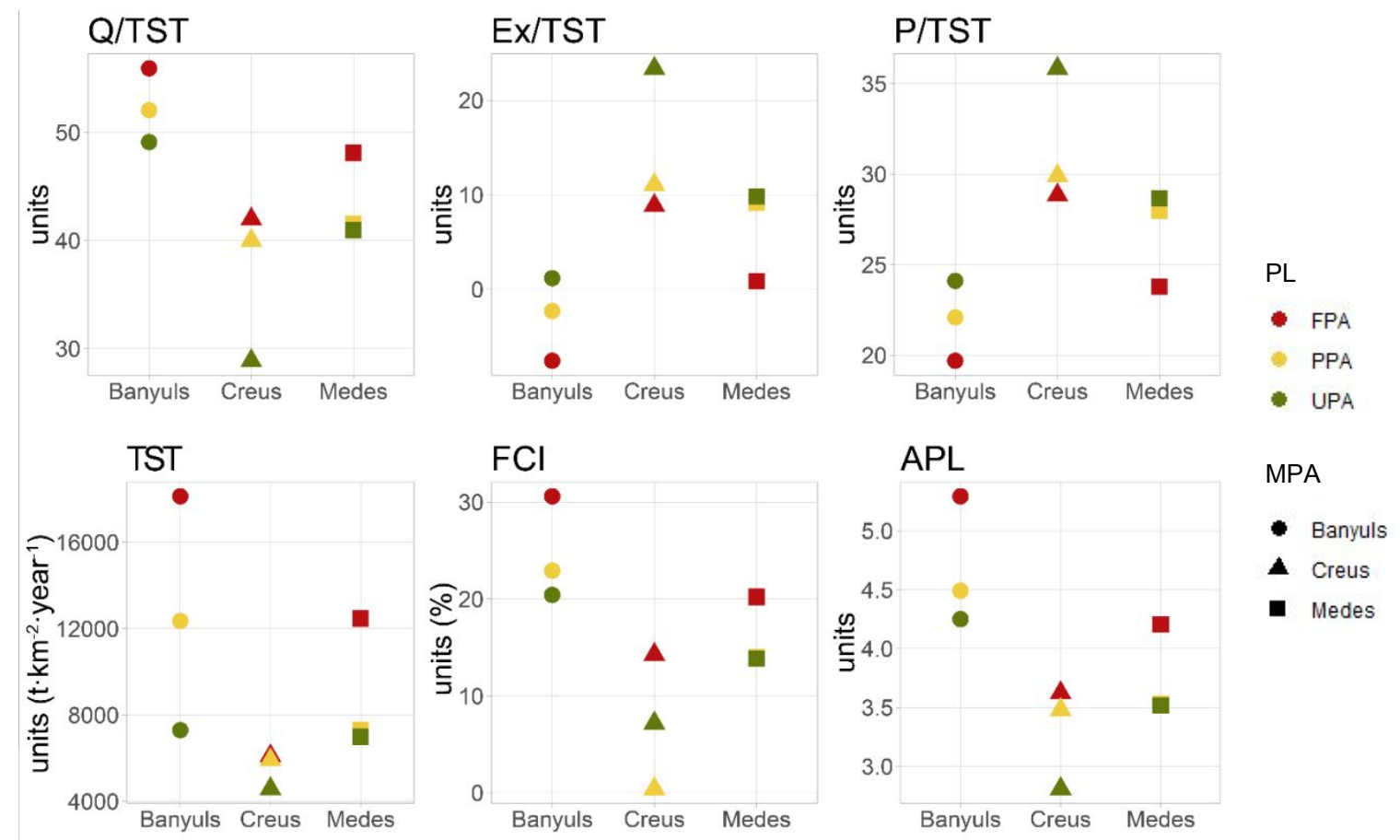

Figure 6. Flow-based indicators of the three MUsprotection levels (PL)PLs (FPA: fully protected area; PPA: partially protected area; UPA: unprotected area) models for each MPA (Cerbère-Banyuls, Cap de Creus and Medes Islands). (Q/TST Consumption ratio, Ex/TST - Export ratio, P/TST - Production ratio, TST - Total System Throughtput, FCl - Finn Cycle Index and APL - Average Path Length). 


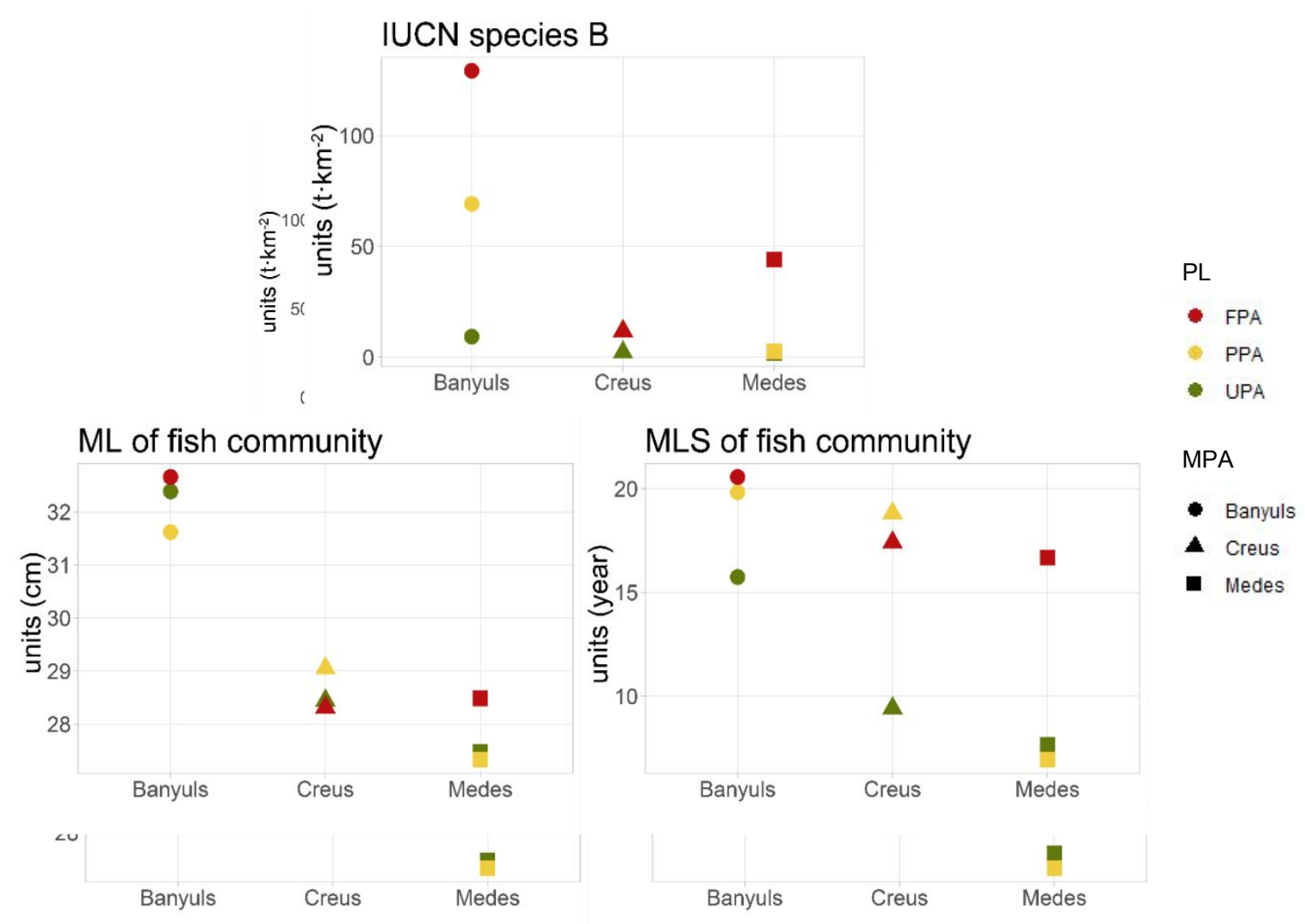

Figure 7. Species-based indicators of the three AUsprotection levels (PL)PLs (FPA: fully protected area; PPA: partially protected area; UPA: unprotected area) models for each MPA (Cerbère-Banyuls, Cap de Creus and Medes Islands). (B - Biomass, $\mathrm{ML}$ - mean length and MLS - mean life span). 


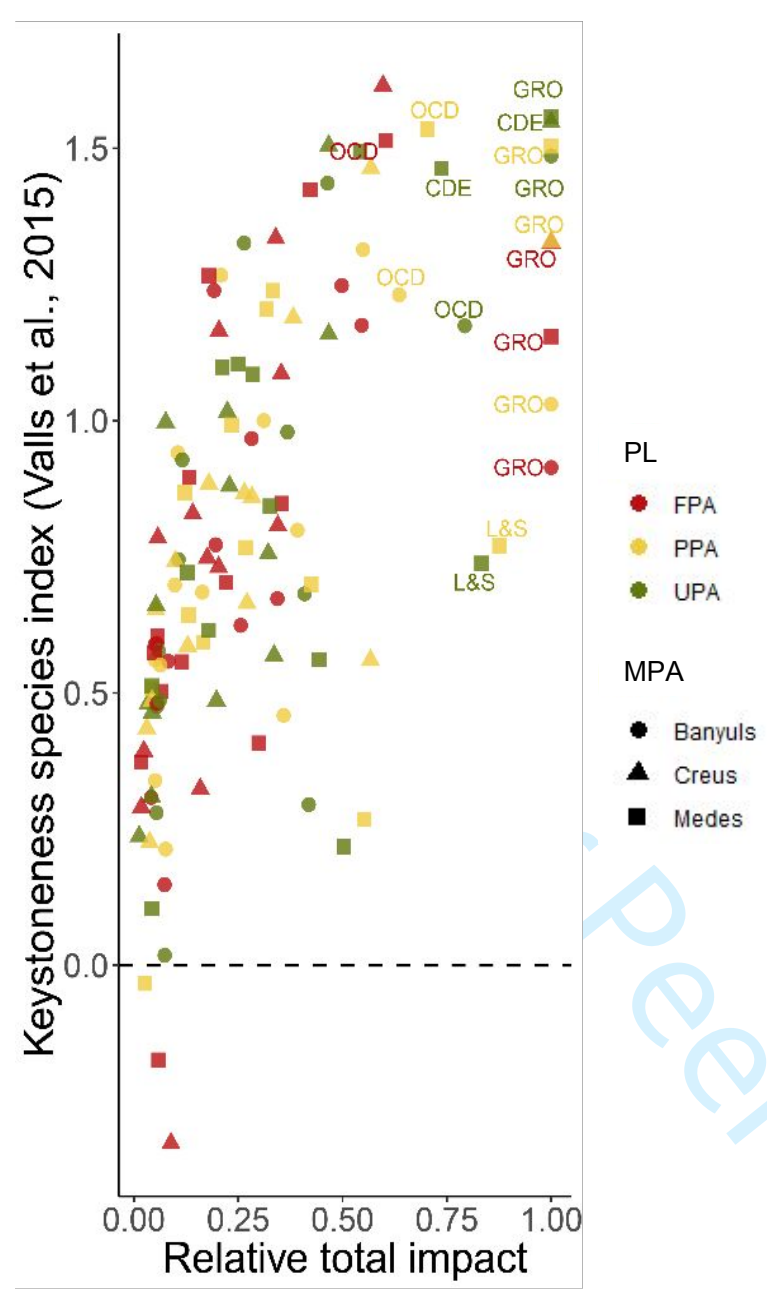

Figure 8. Keystone Index analysis of the three protection levels (PL)MU (FPA: fully protected area; PPA: partially protected area; UPA: unprotected area) models for each MPA (Cerbère-Banyuls, Cap de Creus and Medes Islands). The acronyms identify the functional group with highest keystoneness index and relative total impact. (GRO - groupers; CDE - common dentex; OCD - Other commercial medium demersal fishes; L\&S - Labridae and Serranidae). 

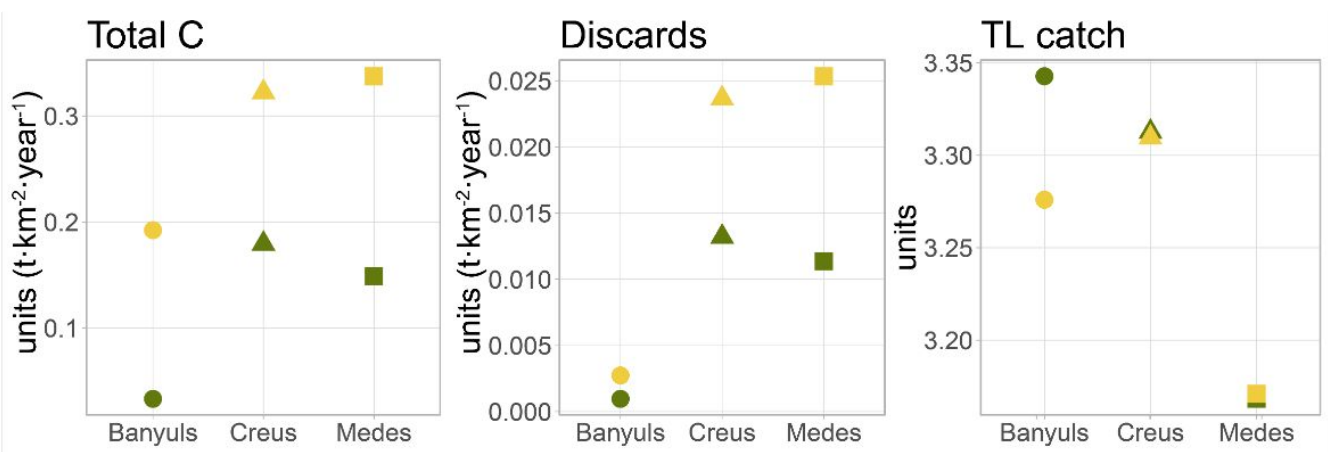

$\mathrm{PL}$
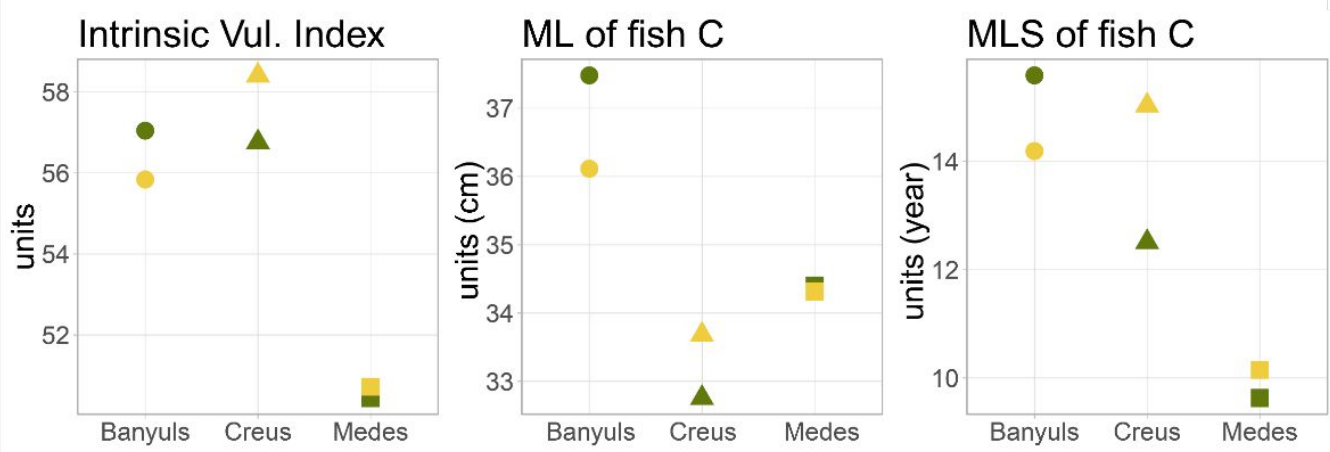

MPA

- Banyuls

- Creus

- Medes

Figure 9. Catch-based indicators of the three MUsprotection levels (PL)PLs (PPA: partially protected area; UPA: unprotected area) models for each MPA (CerbèreBanyuls, Cap de Creus and Medes Islands). (C - Catch; TL - trophic level; ML mean length; MLS - mean life span). 

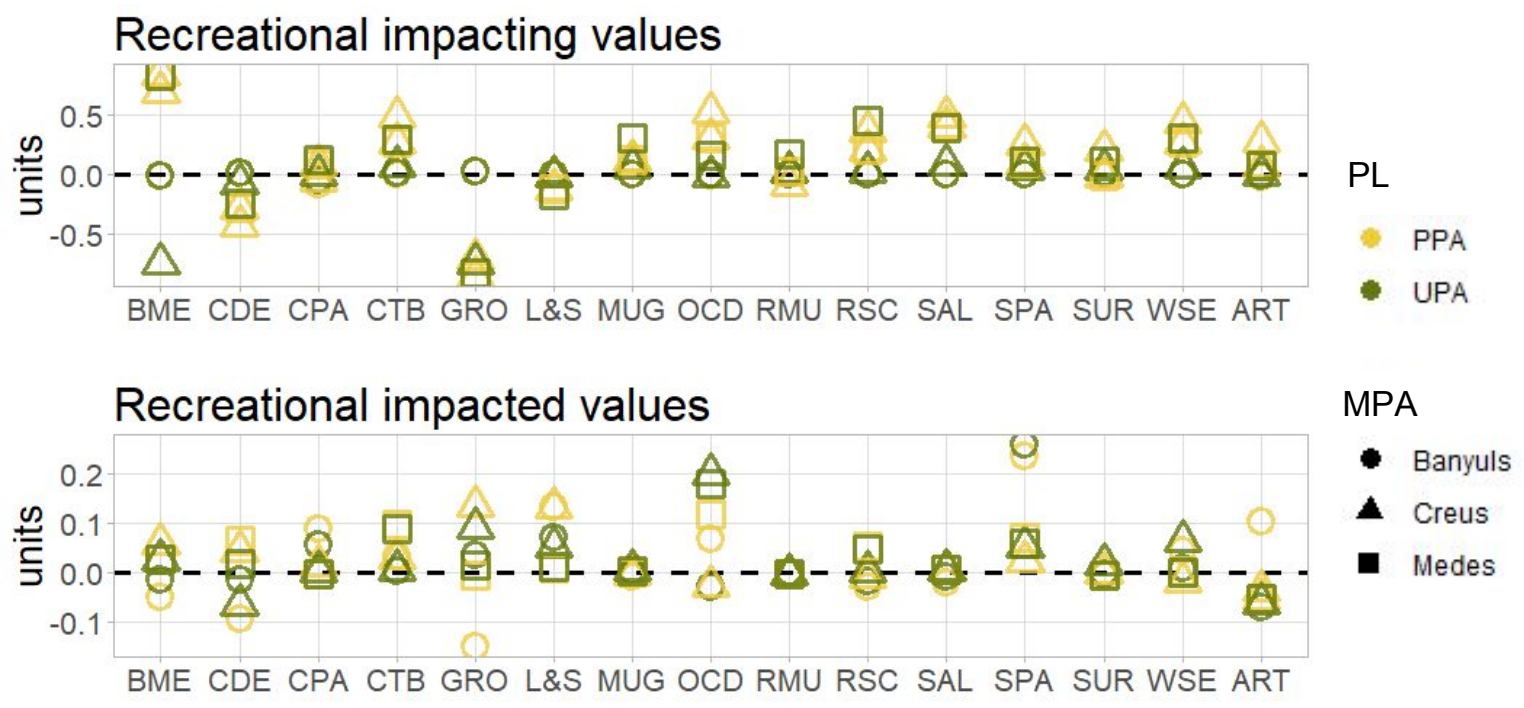

Figure 10. Recreational impacting and impacted values of three protection levels (PL)AU models (PPA: partially protected area; UPA: unprotected area) for each MPA (Cerbère-Banyuls, Cap de Creus and Medes Islands). (BME - brown meagre; CDE - common dentex; CPA - common pandora; CTB - common two-banded seabream; GRO - groupers; L\&S - Labridae and Serranidae; MUG - Mugilidae; OCD - Other commercial medium demersal fishes; RMU - red mullet; RSC - red scorpionfish; SAL - salema; SPA - Sparidae; SUR - striped red mullet; WSE - white seabream; ART - Small scale fishery). 


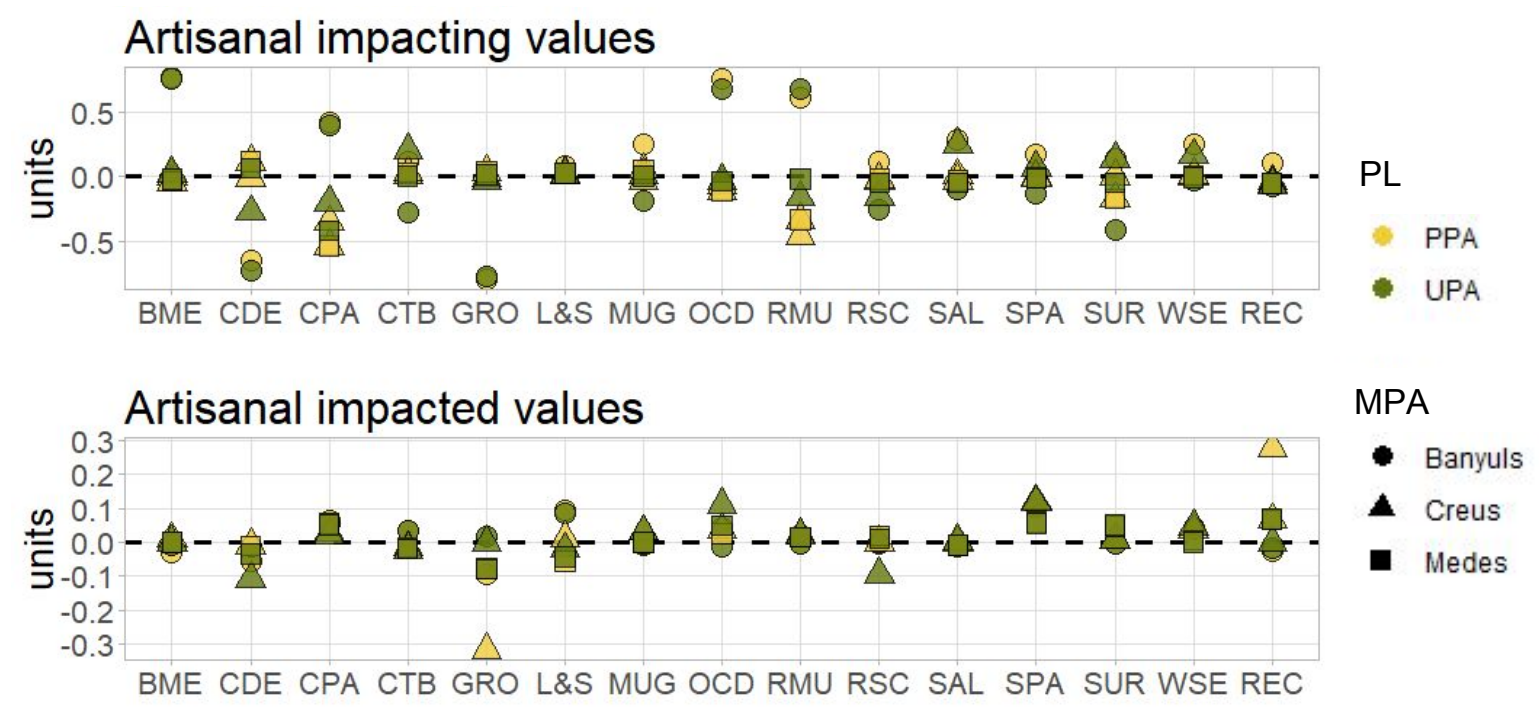

Figure 11. Small scale impacting and impacted values of three protection levels (PL)AU models (PPA: partially protected area; UPA: unprotected area) for each MPA (Cerbère-Banyuls, Cap de Creus and Medes Islands). (BME - brown meagre; CDE - common dentex; CPA - common pandora; CTB - common two-banded seabream; GRO - groupers; L\&S - Labridae and Serranidae; MUG - Mugilidae; OCD - Other commercial medium demersal fishes; RMU - red mullet; RSC - red scorpionfish; SAL - salema; SPA - Sparidae; SUR - striped red mullet; WSE - white seabream; REC - Recreational fishery). 


\section{Supplementary data}

Additional Supplementary material may be found in the online version of this article:

Appendix 1. Supplementary table: Functional groups included for the protection level models showing those present (P) or absent (A) in each MPA (Table S1.1.).

Appendix 12. Supplementary tables: Cerbère-Banyuls, Cap de Creus and Medes MPAs functional groups species composition and methods and references used to estimate the basic input parameters of the nine Ecopath models (Table S1S2.1.); Input parameters and outputs estimate for Cerbère-Banyuls (Table S1 S2.2.), Cap de Creus (Table S1⒉3.) and Medes Islands (Table S1⒉4.) PLAU models.

Appendix 23. Supplementary tables: Diet composition matrix for the protection levelAU models of Cerbère-Banyuls (Table S2S3.1.), Cap de Creus (Table S2S3.2.) and Medes Islands (Table \$2 23.3 .) MPA.

Appendix 34. Supplementary tables: Keystone indexes and Relative Total Impact values for the functional groups included in Cerbère-Banyuls (Table S3S4.1), Cap de Creus (Table S3S4.2) and Medes Islands (Table S3S4.3) protection levelMU models. FPA: fully protected area; PPA: partially protected area; UPA: unprotected area.

Appendix 4ㅁ․ Additional explanatory text about modelling parameterization and balancing procedure.

Appendix 5 6 . Supplementary figure: Flow diagrams of three management unitsprotection levels (FPA: red; PPA: yellow; UPA: green) of Cap de Creus and Medes Islands MPA model_(Figure S6.1.). 
